\title{
Biological Survey of a Prairie Landscape in Montana's Glaciated Plains
}

\author{
Final Report
}

Prepared for:

Bureau of Land Management

Prepared by:

Stephen V. Cooper, Catherine Jean and

Paul Hendricks

December, 2001

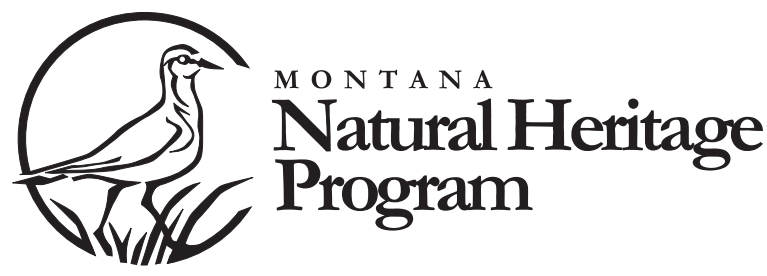




\section{Biological Survey of a Prairie Landscape in Montana's Glaciated Plains}

\section{Final Report}

(c) 2001 Montana Natural Heritage Program

Montana State Library P.O. Box 201800 Helena, Montana 59620-1800 (406) 444-3009

BLM Agreement number 1422E930A960015

Task Order \# 25

This document should be cited as:

Cooper, S. V., C. Jean and P. Hendricks. 2001. Biological Survey of a Prairie Landscape in Montana's Glaciated Plains. Report to the Bureau of Land Management. Montana Natural Heritage Program, Helena. 24 pp. plus appendices. 


\section{Executive Summary}

Throughout much of the Great Plains, grasslands have been converted to agricultural production and as a result, tall-grass prairie has been reduced to mere fragments. While more intact, the loss of mid - and short- grass prairie has lead to a significant reduction of prairie habitat important for grassland obligate species. During the last few decades, grassland nesting birds have shown consistently steeper population declines over a wider geographic area than any other group of North American bird species (Knopf 1994), and this alarming trend has been linked to loss of grassland habitat. However, in the Bitter Creek - Frenchman Creek portion of Montana's Northwestern Glaciated Plains Section, large intact prairie communities can still be found across a diverse landscape. This prairie landscape is the largest remaining intact grassland north of the Highline in Montana and even more significantly, stands out as one of the most extensive naturally functioning glaciated plains grassland in North America. This prairie landscape, a remnant of what once existed more widely in Montana, has important conservation value for grassland-obligate species that are elsewhere threatened by habitat loss.

In 1999 and 2000, the Montana Natural Heritage Program, in cooperation with the Bureau of Land Management, conducted a biological inventory and assessment of the Bitter Creek Frenchman Creek area. The primary objective was to document the distribution and biological significance of this native prairie landscape's vegetation communities and to assess the status of plant and animal species of concern and other grassland obligate species that occur there.

The variable topography and vegetation in the Bitter Creek - Frenchman Creek area support a diverse native vertebrate fauna typical of the northern Great Plains. A complete suite of grassland-obligate birds is still present, including Sprague's Pipit and Baird's Sparrow - both Montana Species of Concern. These and other bird species are present because the grasslands in this region provide a mosaic of structure (in both density and height) and food resources where they can settle and nest successfully. This landscape is also important for other vertebrate species of conservation concern, including a limited number of Black-tailed Prairie Dog colonies that provide breeding sites for Burrowing Owls. Swift Fox now reoccupies some portions of the landscape following releases during the last decade in Canada. Great Plains Toad and Northern Leopard Frog, in decline elsewhere, still occupy some wetlands and permanent streams. Additional surveys will likely reveal the presence of other vertebrate species, especially amphibians, reptiles, and small mammals, of conservation concern in Montana.

Some obligate grassland birds are sensitive to habitat conversion on landscape scales and favor larger grassland patches. Their larger numbers in the Bitter Creek area, relative to other prairie regions in Montana, reflect this preference. Thus, the extensive and contiguous native prairie rangelands of the Bitter Creek - Frenchman Creek study area are important for maintaining diverse communities and large viable populations of native grassland-dependent birds and other animals.

Within the greater Bitter Creek - Frenchman Creek area we identified seven landscape sites, each with a distinctive suite of characteristics, that stand out as exceptional examples of glaciated plains. The extent of the intact prairie and the quality of these landscapes, qualify this part of Montana as an outstanding Great Plains mid-grass prairie landscape. One of the most outstanding areas, the Dry Fork Creek landscape, harbors an extensive, intact tract of northern porcupine grass - thickspike wheatgrass, a rare mid-grass prairie association. This is one of the best - if not the best - stands of its type documented in all of the US Great Plains, making Dry Fork Creek an area of national significance. This important grassland dominates a large block of school trust lands managed by the Montana Department of Natural Resource Conservation and leased for grazing. The state and private lessee have maintained this notable grassland through good stewardship practices. Livestock grazing is highly compatible with natural ecological processes that maintain these grasslands, whereas plowing the grassland for agricultural production would result in a permanent loss of this important grassland. 


\section{Acknowledgements}

Thanks to David Waller, Bureau of Land Management (BLM) wildlife biologist at the Glasgow and Malta Field Offices for providing key information. We also appreciate Steve Klessens and John Fahlgren for sharing their intimate knowledge of the vegetation resources within the study area.

We appreciate Brian Martin, Montana Field Office of The Nature Conservancy, for originally piquing our interest in the study area and continuing to be a source of information, he and Sue Crispin provided insightful editorial comment.

Mr. Lynn Cornwell of Glasgow, MT, whose extensive ranching operations are embedded squarely within the study area, graciously provided access to his private holdings and contributed a stockman's perspective and background information regarding northern Valley County.

Cedron Jones, Montana Natural Heritage Program (MTNHP) designed and produced the study area map and Duane Lund, Natural Resource Information Systems (NRIS) and
Whitney Weber (MTNHP) did likewise for the shaded relief map. Cedron, Martin Miller and Terrie Kenney (MTNHP) processed plant association records, Terrie entered information and photographic images into program databases and Ryan Rausher (FWP) helped make the climate diagram. Mike Roedel (former MTNHP Zoology Program Manager) conducted the initial year of zoological field sampling. Bob Bramblett generously provided information on native fish populations of Rock Creek. The report benefited significantly from our discussions with botanist Bonnie Heidel (MTNHP) regarding the ecology and distribution of prairie communities. Thanks to Joy Lewis (MTNHP) for her editing and production help.

Though this report has profited from the support and contributions of many people, any errors of commission or omission rest with the authors. This project was supported by a challenge costshare agreement between the Bureau of Land Management and the Montana Natural Heritage Program (BLM Agreement Number 1422E930A960015, Task Order \# 25). 


\section{TABLE OF CONTENTS}

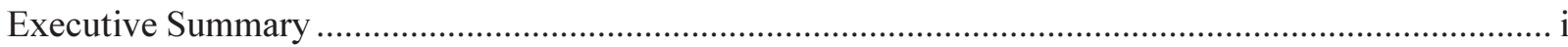

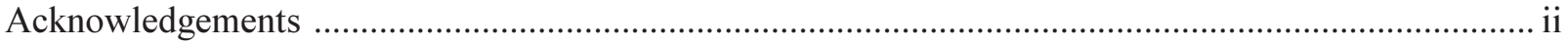

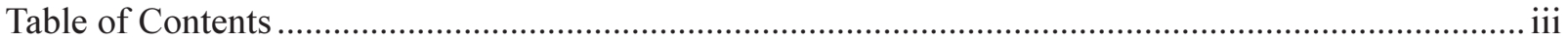

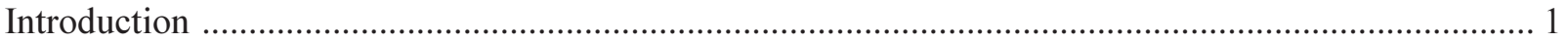

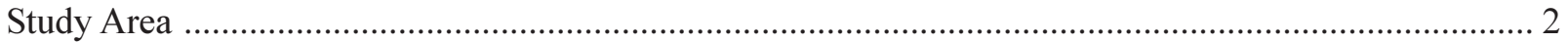

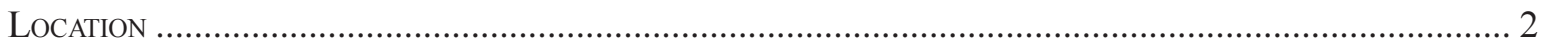

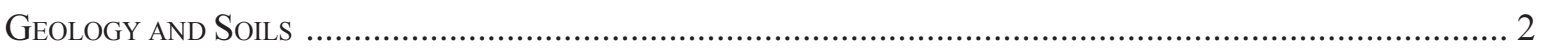

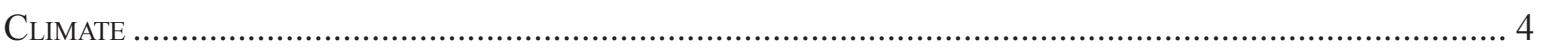

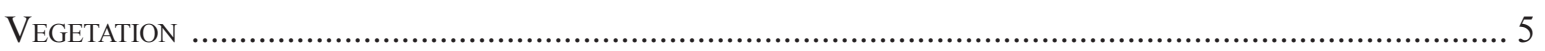

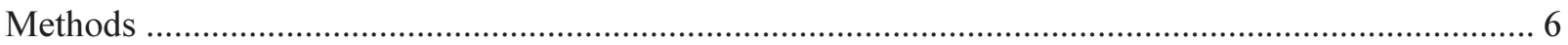

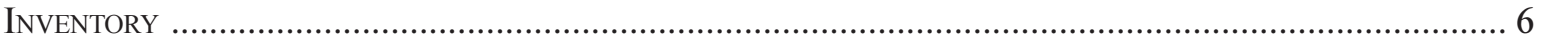

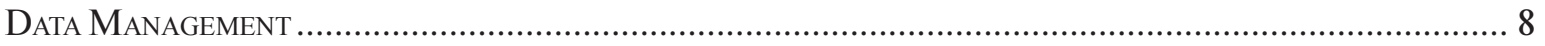

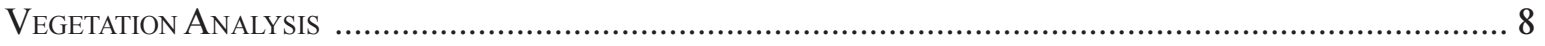

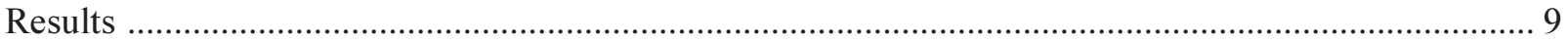

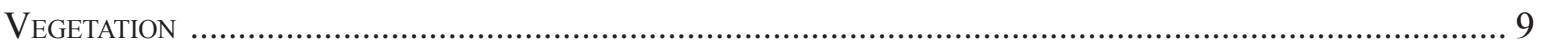

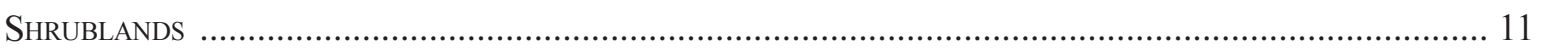

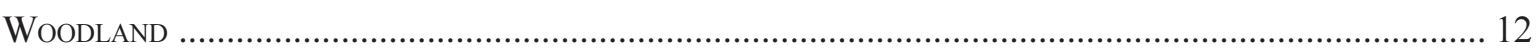

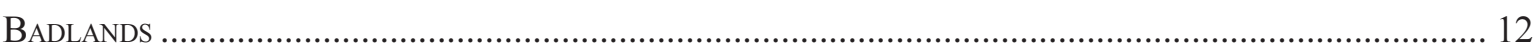

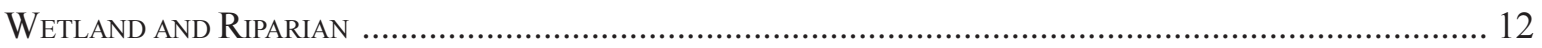

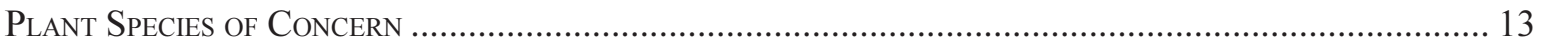

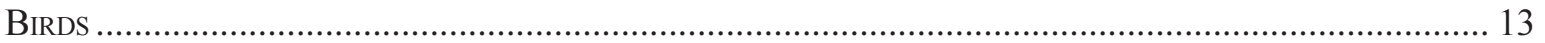

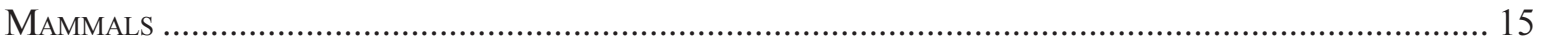

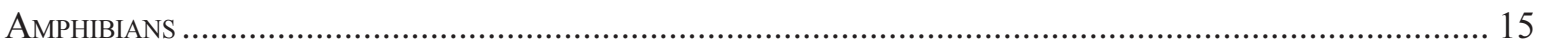

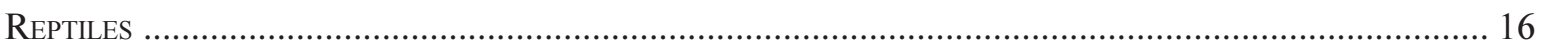

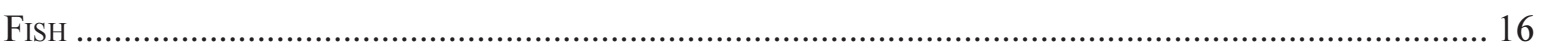

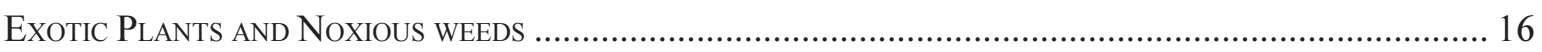

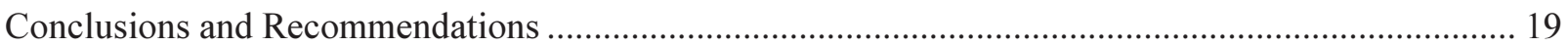

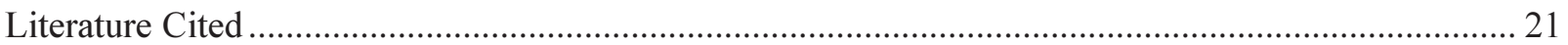

Appendix A: Rangeland Ecological Sites and Plant Associations

Appendix B: Landscape Site Descriptions

Appendix C: Plant Community Descriptions

Appendix D: Plant Community Summary Matrix

Appendix E: Natural Community Photographs 


\section{INTRODUCTION}

Throughout much of the Great Plains, grasslands have been converted to agricultural production and as a result, tall-grass prairie has been reduced to mere fragments. While more intact, the loss of mid- and short- grass prairie has lead to a significant reduction of prairie habitat important for grassland obligate species. During the last few decades, grassland nesting birds have shown consistently steeper population declines over a wider geographic area than any other group of North American bird species (Knopf 1994), and this alarming trend has been linked to loss of grassland habitat. However, in the Bitter Creek Frenchman Creek portion of Montana's Northwestern Glaciated Plains Section, large intact prairie communities can still be found across a diverse landscape. This prairie landscape is the largest remaining intact grassland north of the Highline in Montana and even more significantly, stands out as one of the most extensive naturally functioning glaciated plains grassland in North America. This prairie landscape, a remnant of what once existed more widely in Montana, has important conservation value for grassland-obligate species that are elsewhere threatened by habitat loss.

The persistence of extensive intact prairie grasslands in this region is a result of climate, land ownership and ranching as the predominant land use. As one moves east from the Rocky Mountains across the Great Plains, the effects of the rain shadow diminish and precipitation increases. This is especially evident across Montana's northern Highline, where precipitation patterns vary but generally increase to the east. As the precipitation increases, so does the development of mollic soils suitable for small grain production.
Unlike Sheridan County, which has more precipitation and where glaciers deposited deep glacial till, mollic soils are less developed in northern Phillips and Valley Counties. Early "sodbusters" focused on the more productive mollisols, and largely ignored the extensive grasslands of this region, leaving them mostly intact.

Some sodbusting did take place in less productive areas characterized by Aridisols and Inceptisols. Early homesteaders plowed and seeded the native range to grain crops, but the drought of the 1920's and early 1930's produced insufficient yields to support a family, and many of these settlers abandoned their farms. The Bankhead-Jones Act in 1935 authorized the government to buy back these sub-marginal lands, and ownership became concentrated among fewer parties, with ranching rather than farming as the dominant land use.

One last and very important reason for this extensive intact prairie was the federal government's transfer of one section in each township to the state as school trust lands. Parcels that would have fallen on Indian reservations were consolidated into large blocks west of Fork Peck Indian Reservation. These lands have since been leased by the state

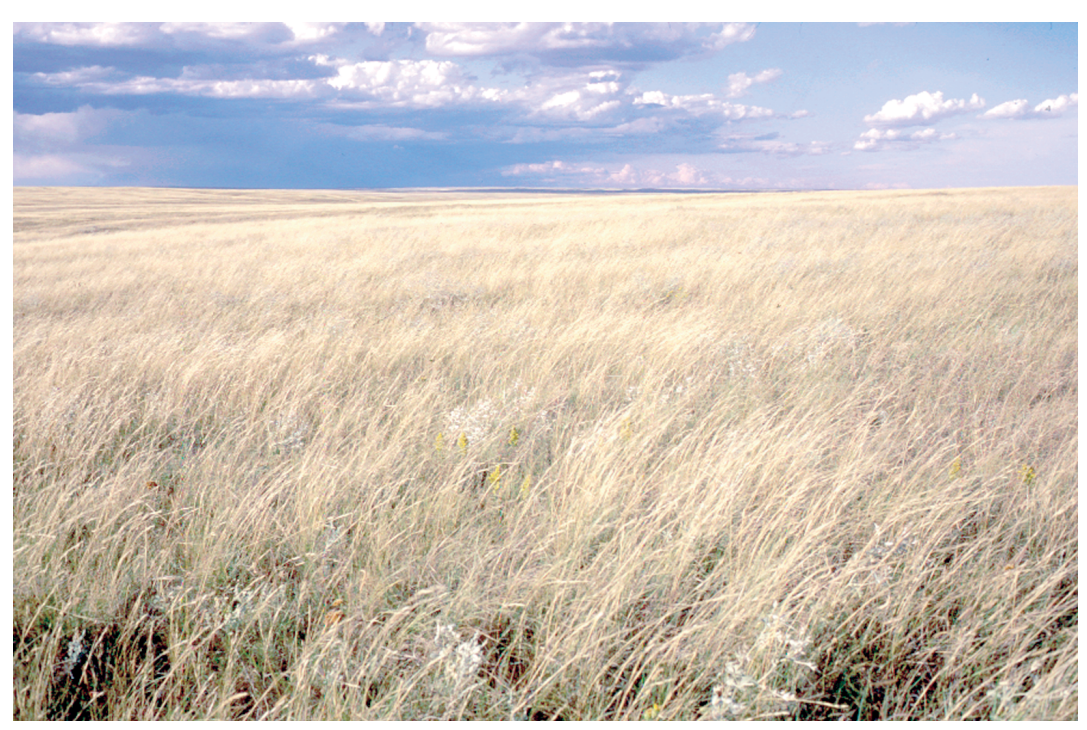


for livestock grazing and maintained as native prairie. This legacy has left us with an impressive native prairie region in Montana's glaciated plains.

Before this study, little was known about the native grasslands of northern Phillips and Valley Counties, except that thickspike wheatgrass (Elymus lanceolatus) and northern porcupine grass (Hesperostipa curtiseta) were more prevalent than western wheat grass and needle-and-thread (DeVelice et al. 1995). In 1999 and 2000, Natural Heritage Program ecologists and zoologists conducted surveys in the Bitter Creek and Frenchman Creek region of northern Phillips and Valley Counties. This landscape has extensive intact native prairie, environmental variability resulting in high species diversity, and ecosystem processes that function at rates, scales and within the range of historical variation believed to have existed prior to European settlement.

Our primary objective was to document the distribution and biological significance of native prairie communities and the status of plant and animal species of concern. In this report we:

Identify high quality natural vegetation and intact landscapes in the Montana glaciated plains.

$>$ Evaluate the distribution, habitats and status of sensitive plant and animal species (with a focus on reptiles, amphibians, and birds) and natural plant communities.

$>$ Identify stewardship opportunities for native species and habitat conservation.

\section{STUDY AREA}

\section{LOCATION}

Bitter and Frenchman Creeks (Figure 1) are located in northern Phillips and northwestern Valley counties in northeastern Montana. This area stretches from the Canadian border south about 40 miles, reaches up to 60 miles in width, and includes the Bitter Creek Frenchman Creek drainages in the Milk river watershed. The area is within the Montana Glaciated Plains, a subsection of the Northwestern Glaciated Plains Section in the Great Plains-Palouse Dry Steppe Province (Nesser et al. 1997).

\section{Geology ANd SoILS}

The plains landscape of northern Valley and Phillips Counties has modest vertical relief rising from the Milk River Valley at 2,000 feet to 3,300 feet on gentle ridges near Opheim, Montana. The gentle, rolling nature of today's landscape contrasts with episodes of past glaciation when this area was scoured by at least two episodes of continental glaciation by the Keewatin ice sheet. Glacial till, outwash and drift of varying thickness mantle the rolling to undulating terrain known as a glacial till plain. In areas lacking surface drainage, small wetlands and ponds are sporadically distributed and may have formed as filled-in kettle holes created when stranded ice blocks melted following glaciation.

Clay shale, dark gray and of marine origin, is the most extensive lithologic / geologic substrate in the study area, extending from Canada to the Fort Peck Reservoir. Sandstone is only weakly represented in the area; it underlies plateaus exposed in the breaks along the eastern portion of Little Porcupine and at the head of Big Porcupine Creek where it is exposed in the steep escarpments above the Milk River and Rock Creek valleys.

The Bitter Creek Badlands is a geomorphically distinct area drained by Eagle, Bitter, and Chisholm Creeks and characterized by boldly dissected and highly eroded terrain. The exposed substrates are principally dark gray shales. Mounds of highly eroded bentonite also distinguish this landscape. Other outcrops of bentonite are found scattered throughout the area. Six soil orders (Alfisol, Aridisol, Mollisol, Inceptisol, Entisol, and Histosol) are recognized for the area; only the first three are associated with broad climatic features. 
Figure 1. Bitter Creek - Frenchman Creek Study Area.

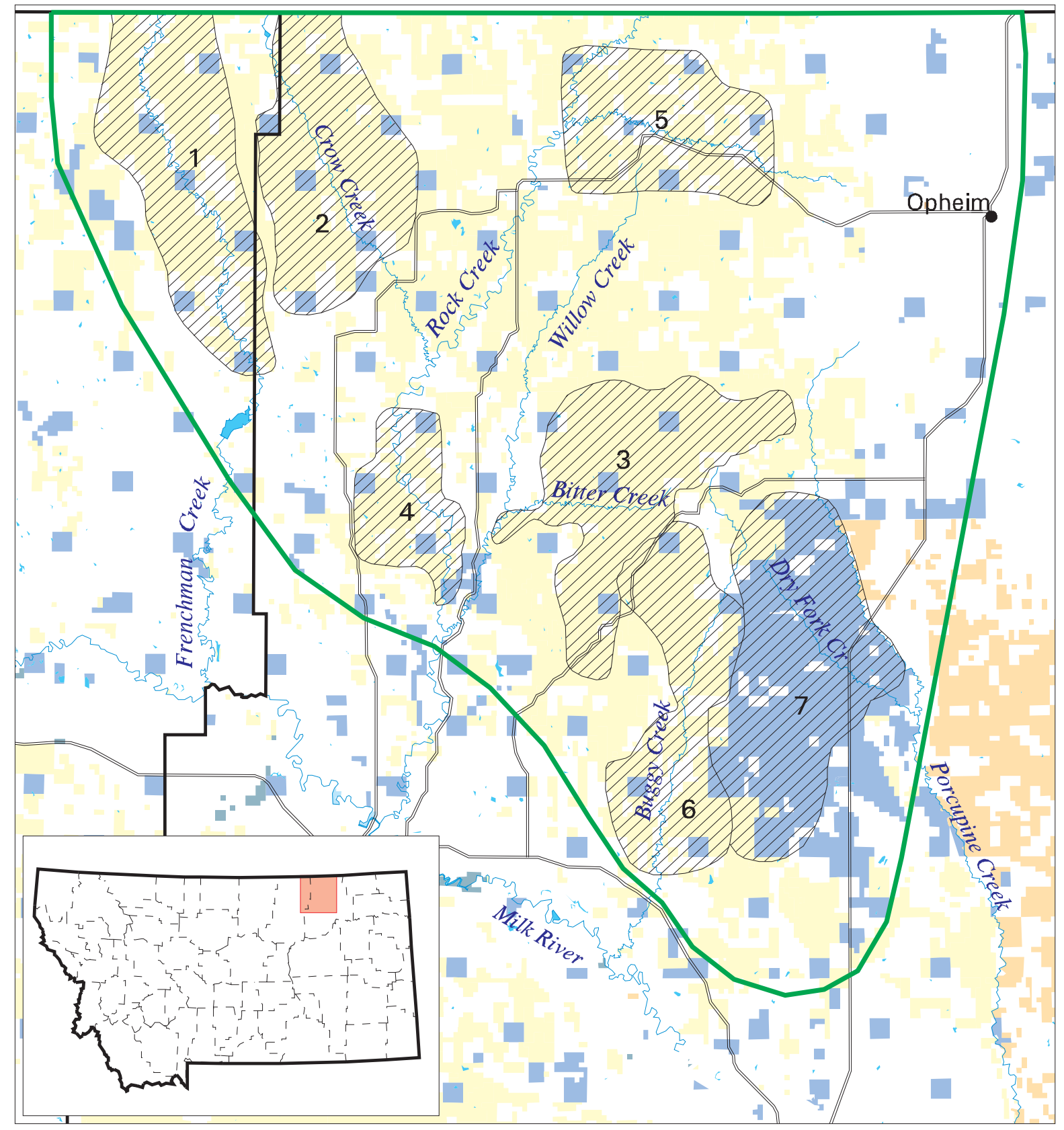

1 Frenchman Creek Landscape

2 Crow Creek Landscape

3 Bitter Creek Badlands Landscape

4 Rock Creek Canyon Landscape

5 South Fork Rock Creek Landscape

6 Buggy Creek Landscape

7 Dry Fork Creek Landscape

0

10

Miles

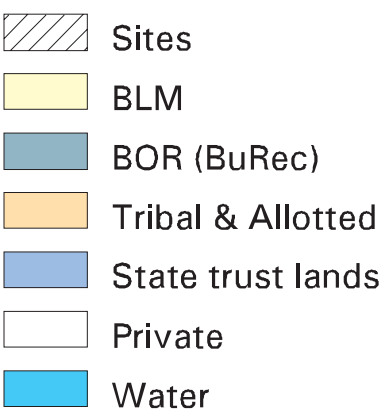


Table 1. Soils present in the Bitter Creek - Frenchman Creek Study Area arranged alphabetical by Soil Series.

\begin{tabular}{|l|l|l|l|}
\hline Soil Series & Family & Subgroup & Order \\
\hline Absher & Fine, montmorillonitic & Borollic Natrargids & Aridisol \\
\hline Cabbart & Loamy, mixed (calcareous), frigid & Ustic Torriorthents & Entisol \\
\hline Delpoint & Fine-silty, mixed & $\begin{array}{l}\text { Borollic } \\
\text { Camborthids }\end{array}$ & Aridisol \\
\hline Dilts & Clayey, montmorillonitic, acid, frigid, shallow & Ustic Torriorthents & Entisol \\
\hline Elloam & Fine, montmorillonitic & Borollic Natrargids & Aridisol \\
\hline Lisam & $\begin{array}{l}\text { Clayey, montmorillonitic (calcareous), frigid, } \\
\text { shallow }\end{array}$ & Ustic Torriorthents & Entisol \\
\hline Nishon & Fine, montmorillonitic, frigid & Typic Albaqualfs & Alfisol \\
\hline Nobe & Clayey, montmorillonitic (calcareous), frigid & Ustic Torriorthents & Entisol \\
\hline Phillips & Fine, montmorillonitic & Borollic Paleargids & Aridisol \\
\hline Scobey & Fine, montmorillonitic & Aridic Argiborolls & Mollisol \\
\hline Sunburst & Fine, montmorillonitic (calcareous), frigid & Ustic Torriorthents & Entisol \\
\hline Thoeny & Fine, montmorillonitic & Borollic Natrargids & Aridisol \\
\hline Vaeda & Fine, montmorillonitic, nonacid, frigid & Ustic Torriorthents & Entisol \\
\hline
\end{tabular}

Stream drainages are generally well established across the landscape and some streams, notably Frenchman and Rock Creeks have carved deep valleys, exposing the underlying shale and sandstone formations.

\section{Climate}

This part of Montana is considered semi-arid, with precipitation ranging from 10 to 14 inches a year (Figure 2). The climate is a temperate continental type with frigid winters, warm to hot summers, and a precipitation regime that peaks in late spring-early summer (June) with steady, soaking, frontal system rains. Summer rainfall comes mainly from convection storms (cloudbursts, thunderstorms) that typically deliver scattered amounts of rain in intense bursts and may be accompanied by crop destroying, large-diameter hail and flash flooding. Where rainfall exceeds evaporation, conditions are suitable for agriculture, particularly cereal grains. The growing season is typically $110-130$ days with approximately $70-80 \%$ of annual precipitation falling during that period. The Opheim vicinity, with only 100 days frost-free, stands as the exception because of its higher elevation and northern location.
The pronounced year-to-year variability in precipitation is typical for semi-arid continental climates. Severe drought conditions occur on average in two out of every ten years. Data from Redstone, Montana, highly comparable to climate stations in the study area, indicate one year in ten will have a total annual precipitation of less than 8.0 inches or more than 18.0 inches (Richardson and Hanson 1977).

Average daily minimum temperatures occurring in January at Hinsdale $4 \mathrm{SW}$ and Opheim $10 \mathrm{~N}$, are $6.5^{\circ} \mathrm{F}$ and $-3.6^{\circ} \mathrm{F}$, respectively; average daily maximums occur at Hinsdale in July $\left(83.1^{\circ} \mathrm{F}\right)$ and at Opheim in August $\left(82.1^{\circ} \mathrm{F}\right)$. These average daily highs and lows do not account for single day extremes; for example Medicine Lake, which lies at the same latitude and only slightly to the east has the highest temperature on record $\left(117^{\circ} \mathrm{F}\right)$ for Montana.

Snow can be a significant ecological factor in the northern Great Plains. Snow depths on level surfaces seldom exceed 3-6 inches at any one time. However, wind redistributes snow to lee positions (usually northeast- to east-facing 
Figure 2. Climate diagram showing average monthly temperature and precipitation for Hinsdale, MT. The hatched bar across the bottom shows growing season length or the number of frost-free days where the mean daily minimum temperature is above 0 degrees Centigrade. The title bar shows the weather station location, elevation, mean annual temperature, mean annual precipitation, and the period of observation

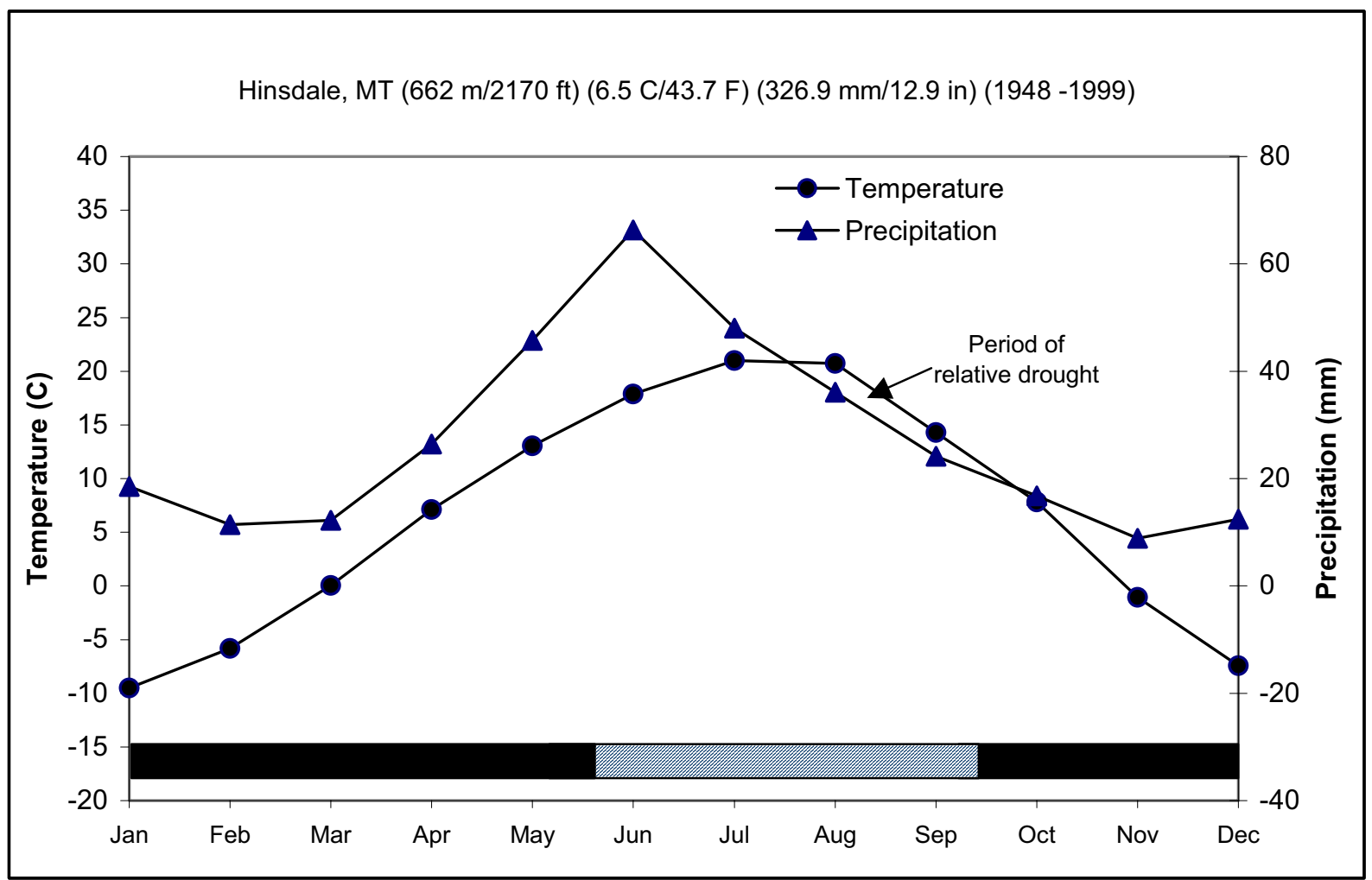

exposures) and swales, where subsequent compaction results in considerably higher moisture content than on the flats. Snow redistribution may play an under-appreciated role in the distribution of plant communities in plains environments. The heaviest snowfalls consistently occur in late winter to early spring and are almost invariably accompanied by high winds causing blizzard conditions and massive drifting.

\section{Vegetation}

The landscape is a mix of short- and mid-grass prairie communities intermixed with shrub steppe, badlands and riparian systems. Steppe vegetation is the result of the semi-arid continental climate; the highly variable precipitation favors short rooted herbaceous perennial grasses and deep rooted shrubs over forest or woodlands. Short- and mid-grass prairies co-exist due to variability in precipitation; shorter, drought-resistant grasses such as blue grama (Bouteloua gracilis) increase in percent cover during times of drought. Mid-grasses, principally the rhizomatous thickspike wheatgrass and western wheatgrass (Pascopyrum smithii) and the bunch-forming prairie junegrass (Koeleria macrantha), needle-and-thread (Hesperostipa comata) and porcupine grass increases under more favorable moisture conditions. 


\section{METHODS}

\section{INVENTORY}

Our survey was designed to systematically inventory broad ecological landscapes and evaluate the distribution, habitats and status of the biological resources. We conducted searches of the Heritage databases and available literature, and consulted with agency biologists, before conducting fieldwork to identify documented and potential species of concern in the area. We then compiled topographic maps, aerial photographs, and soil survey data for the study area. In addition to leads generated from aerial photo and topographic map interpretation, local experts — particularly BLM field personnel assisted in identifying unique aspen, fen and shrubland locations as well as notable areas of extensive prairie worthy of investigation.

Field surveys were conducted during the summers of 1999 and 2000 . The first inventory season focused on landscape scale vegetation surveys over a range of environmental conditions in the western portion of the study area. The second inventory season focused on the composition and character of intact landscapes with attention towards documenting new and poorly understood plant associations.

Faunal surveys were more general in nature, due to constraints on allotted field time and weather conditions. Our objectives were to document animal species of concern (Carlson 2001) throughout the study area, and in specific landscapes of interest. We covered as much of the Bitter Creek - Frenchman Creek area as possible both years, emphasizing amphibians and reptiles in 1999, and birds in 2000. We also inventoried all prairie dog colonies to document presence or absence of prairie dog-associated animal species.

Amphibians/reptiles were surveyed with timed searches at selected wetlands (see Heyer et al. 1994, Olsen et al. 1997 for discussion of sampling methods). Searches included examination of the shoreline while we walked the perimeter, periodically sweeping the nearshore water with a dip net. We targeted springs, and also surveyed reservoirs and stock ponds as time permitted; additional sites included those suggested to us by agency biologists. At springs we walked the entire site, including the outflow, and documented all amphibians and reptiles encountered. We did not specifically survey for reptiles in the uplands, but were vigilant for road-kills and sunning individuals as we drove roads. We also documented reptiles that were incidentally encountered.

We recorded all birds encountered during amphibian/reptile site surveys and in other areas traversed on foot. We also frequently stopped and listened for grassland bird species of concern, especially Sprague's Pipit (Anthus spragueii) and Baird's Sparrow (Ammodramus bairdii), while driving between sites. Counts were not randomly or systematically located, but rather designed to generate species lists for the area (see Bibby et al. 2000 for a comprehensive treatment of avian counting procedures) and identify distributions and habitat associations. During stops in the car or while on foot, usually lasting 3-5 minutes, we recorded all bird species detected within a radius of about 250 meters and also took notes on the vegetation present (especially dominant species and estimated height). We recorded locations of point counts to the nearest quarterquarter section, and noted time of day for each count to determine if target species were vocal and therefore detectable throughout the day or during specific time-periods.

Common and scientific nomenclature of birds cited in this report follow the seventh edition of the A.O.U. Checklist (A.O.U. 1998) and supplements (A.O.U. 2000), mammals follow Jones et al. (1986) and Foresman (2001), amphibians and reptiles follow Stebbins (1985), and fish follow Holton and Johnson (1996). 
The principal floristic references for plant identification are "Flora of the Great Plains" (The Great Plains Flora Association, (1977, 1986), "Vascular Plants of Montana" (Dorn, 1984) and "Flora of the Pacific Northwest" (Hitchcock and Cronquist (1973). Looman's book titled "Prairie Grasses, identified and described by vegetative characters" (1982) was helpful for identifying grasses in their vegetative state. Plant nomenclature follows Kartesz (1999); consequently, recent taxonomic revisions to the wheat-grass tribe (Elymus and Agropyron) have resulted in new names replacing the more familiar scientific names that have been in general use. Thus western wheatgrass, Agropyron smithii in Booth (1950) and Hitchcock and Cronquist (1973) and Elymus smithii in Dorn (1984), is now referenced as Pascopyrum smithii. Refer to Table 2 for synonymy of dominant and indicator species used in plant association names.

Table 2. Synonymy of scientific names for indicator and characteristic plant species (alphabetically arranged in $2^{\text {nd }}$ column).

\begin{tabular}{|c|c|c|c|}
\hline Common name & $\begin{array}{c}\text { In: Booth (1950), (1966) } \\
\text { or } \\
\text { Great Plains Flora Assoc. } \\
(1986)\end{array}$ & In: Dorn (1984) & $\begin{array}{c}\text { In: Kartesz \& } \\
\text { Meacham (1999) }\end{array}$ \\
\hline Thickspike Wheatgrass & Agropyron dasystachyum & Elymus lanceolatus & Elymus lanceolatus \\
\hline Bearded Wheatgrass & Agropyron caninum & Elymus trachycaulus & Elymus trachycaulus \\
\hline Western Wheatgrass & Agropyron smithii & Elymus smithii & Pascopyrum smithii \\
\hline Little Bluestem & Andropogon scoparius & Schizachyrium scoparium & Schizachyrium scoparium \\
\hline Bluebunch Wheatgrass & Agropyron spicatum & Elymus spicatus & Pseudoroegneria spicata \\
\hline Gardneri's Saltsage & Atriplex nuttallii & Atriplex gardneri & Atriplex gardneri \\
\hline Rillscale & Atriplex dioica & Atriplex suckleyi & Endolepis dioica \\
\hline Needleleaf Sedge & Carex eleocharis & Carex stenophylla & Carex duriuscula \\
\hline Sun Sedge & Carex heliophila & Carex pensylvanica & $\begin{array}{l}\text { Carex inops ssp. } \\
\text { heliophila }\end{array}$ \\
\hline Woolly Sedge & Carex lanuginosa & Carex lanuginosa & Carex pellita \\
\hline Rubber Rabbitbrush & Chrysothamnus nauseosus & Chrysothamnus nauseosus & Ericameria nauseosa \\
\hline Inland Saltgrass & Distichlis spicata var. stricta & Distichlis stricta & Distichlis spicata \\
\hline Few-headed Spikerush & Eleocharis pauciflora & Eleocharis pauciflora & Eleocharis quinueflora \\
\hline Prairie Junegrass & Koeleria pyramidata & Koeleria macrantha & Koeleria macrantha \\
\hline Common Milfoil & Myriophyllum spicatum & Myriophyllum spicatum & Myriophyllum sibiricum \\
\hline Indian Ricegrass & Oryzopsis hymenoides & Oryzopsis hymenoides & Achnatherum hymenoides \\
\hline Littleseed Ricegrass & Oryzopsis micrantha & Oryzopsis micrantha & Piptatherum micranthum \\
\hline Sandberg Bluegrass & Poa sandbergii & Poa secunda & Poa secunda \\
\hline Water Smartweed & Polygonum coccineum & Polygonum amphibium & Polygonum amphibium \\
\hline Shrubby Cinquefoil & Potentilla fruticosa & Potentilla fruticosa & $\begin{array}{l}\text { Dasiphora fruticosa ssp. } \\
\text { floribunda }\end{array}$ \\
\hline Silver-leaved Scurfpea & Psoralea incana & Psoralea argophylla & Pediomelum argophyllum \\
\hline Lemon Scurfpea & Psoralea lanceolata & Psoralea lanceolata & Psoralidium lanceolatum \\
\hline Hardstem Bulrush & Scirpus acutus & Scirpus acutus & Schoenoplectus acutus \\
\hline Needle-and-thread & Stipa comata & Stipa comata & Hesperostipa comata \\
\hline $\begin{array}{l}\text { Northern Porcupine } \\
\text { Grass }\end{array}$ & Stipa curtiseta & $\begin{array}{l}\text { Stipa spartea (implicit as } S . \\
\text { s. var. curtiseta) }\end{array}$ & Hesperostipa curtiseta \\
\hline Green Needlegrass & Stipa viridula & Stipa viridula & Nassella viridula \\
\hline Sea Blite & Suaeda depressa & Suaeda calceoliformis & Suaeda calceoliformis \\
\hline
\end{tabular}


In this report, each species is referenced by both scientific and common name the first time it is mentioned. Common names are based mainly on a national list developed by the Natural Resource Conservation Service (2001). To a lesser degree, we reference common names cited by Region 1 of the U. S. Forest Service.

We developed a preliminary cross-reference (Appendix A) between Natural Resource Conservation Service (NRCS) rangeland ecological sites and plant associations tracked by the Montana Natural Heritage Program. Some plant associations have wide ecological amplitude and occur across a range of ecological sites e.g. Western wheatgrass green needlegrass can be found in the overflow and silty ecological sites whereas, Western wheatgrass - inland saltgrass is found only in the Saline Lowland. The Bitter Creek Frenchman Creek study area captures the vast majority of the ecological sites identified for this region (MLRA 52, Brown Glaciated Plains). We did not encounter sands or shallow-to-gravel ecological sites during our inventory, however they may exist in the area.

Literature and stand data on file at the Montana Natural Heritage Program was reviewed to produce an initial working list of the plant associations in the study area. Until recently, there has been little work describing natural vegetation in this part of Montana. Valley County soil survey (Bingham et al. 1984), and range site descriptions (NRCS 1981) provide valuable forage production values for the most common grassland vegetation of Valley County. We completed a preliminary vegetation classification of northeastern Montana in 195 (DeVelice et al.) and our recent study in Sheridan County, Montana (Heidel et al. 2000) synthesized new ecology plot data and incorporated the work of others (Lesica 1987a, 1987b, Cooper and Heidel 1999). Apart from these reports, the most pertinent vegetation information came from studies in adjoining states and provinces, and from the recently compiled state and regional
National Vegetation Classification System (NVCS) for Great Plains states (Reid et al. 1999, Faber-Langendoen 1999).

To survey plant associations, we used a combination of vegetation sample plots and an abbreviated Rapid Ecological Assessment (REA) technique. Circular 1/10-acre vegetation plots were established in stands with homogeneous vegetation and uniform environmental conditions. We recorded vegetation structure and floristic composition, plot location, environment, disturbance and biotic conditions for 30 intensive plots in 1999 and 48 in 2000 . We used the REA technique to characterize the vegetation across the landscape catena. With this technique, composition and cover of dominant species are recorded for all communities across environmental gradients. This REA technique is favored where the vegetation community is already described or when a rapid assessment meets the project objective.

\section{Data Management}

All plot data were transcribed to a computerized database for analysis and permanent storage in MTNHP data system. New records of outstanding examples of natural communities and populations of plant and animal species of concern were also georeferenced, digitized and documented as element occurrence records in the data system.

\section{Vegetation Analysis}

We summarized the community diversity and conservation values by reviewing 155 ecology plots using data acquired in this study, as well as, relevant data from other regional sampling efforts (DeVelice et al. 1995, Heidel et al. 2000). We organized our findings and named plant association in a manner consistent with the National Vegetation Classification System (Grossman et al. 1998). This system uses recurring vegetation attributes, emphasizes natural existing conditions, and can be used to identify vegetation units based on both quantitative and, in some cases, qualitative 
data. The NVCS is hierarchical and combines floristics at the lowest levels (associations and alliances) and structure (physiognomy) and overarching climate conditions at the highest levels. The plant association is defined in terms of the dominant species of the uppermost vegetation layer, and any co-dominant species, diagnostic species, or the dominant species of shorter vegetation layers.

Species composition and cover for each plot were compared to existing classification schemes to determine the community type assignment. Plot assignments to plant association were also evaluated in terms of abiotic site characteristics. If plots did not correspond with an existing type, then a new or provisional type was created. New types were assigned a name according to the dominant, or less frequently, a diagnostic (indicator) species in the uppermost vegetation layer; a codominant or diagnostic species from this same layer, or a lower layer, is sometimes included to increase specificity. For instance, an easily recognized riparian plant association, silver sagebrush / thickspike wheatgrass (Artemisia cana / Elymus lanceolatus) can have increased specificity by including green needlegrass (Nassella viridula) in the name as a cooccurring species e.g. Artemisia cana / Elymus lanceolatus - Nassella viridula. In this case, green needlegrass implies a near climax and better condition stand.

\section{RESULTS}

The Bitter Creek - Frenchman Creek area is an exceptional example of intact glaciated plains. The extent of the intact prairie and the quality of the landscape setting qualify this part of Montana as an outstanding Great Plains midgrass prairie landscape. Climate, soil, and geomorphic process have created a highly variable landscape with diverse vegetation pattern and structure, which provide valuable wildlife habitat. Many portions of the area support high quality natural vegetation with a complete suite of grassland obligate birds.
We identified seven landscapes sites, each with distinctive characteristics that stand out as exceptional examples of glaciated plains (detailed in Appendix B) and provide extensive high quality habitat for plants and animals. One of the most impressive areas, the Dry Fork Creek landscape, harbors an extensive, intact tract of what has become a rare mid-grass prairie type consisting of northern porcupine grass - thickspike wheatgrass. This is one of the best - if not the best - stands of its type documented in all of the US Great Plains, making Dry Fork Creek an area of national significance. This important grassland dominates a large block of school trust lands managed by the Montana Department of Natural Resource Conservation and leased for grazing.

The following sections summarize the distribution, habitats and status of birds, mammals, amphibians, reptiles, fish, plants species of concern, and natural communities in the study area.

\section{Vegetation}

The status, distribution and habitat for 58 native plant communities found in the Bitter Creek - Frenchman Creek area are given in Appendix C. Where information is adequate, descriptions consist of a summary of their distinguishing attributes, environmental setting, state and county distributions and management or ecological considerations. Many of these are newly described, highly productive grassland plant associations that are dominated (or indicated) by one of two species - northern porcupine grass and thick-spike wheatgrass. Both northern porcupine grass and thick-spike wheatgrass are much more prevalent in Canada than in the U.S. and as a consequence are under-represented in vegetation ecology literature for the U.S.

In this region of Montana, cool-season rhizomatous wheatgrass (Elymus \& Pascopyrum), needlegrass (Stipa spp.), bluegrass (especially Poa secunda and Poa 
Figure 3. Locations of plants and animals of concern on record at the Montana Natural Heritage Program. Bird points represent observations of Baird's sparrow, loggerhead shrike, burrowing owl, ferruginous hawk, Sprague's pipit and common tern.

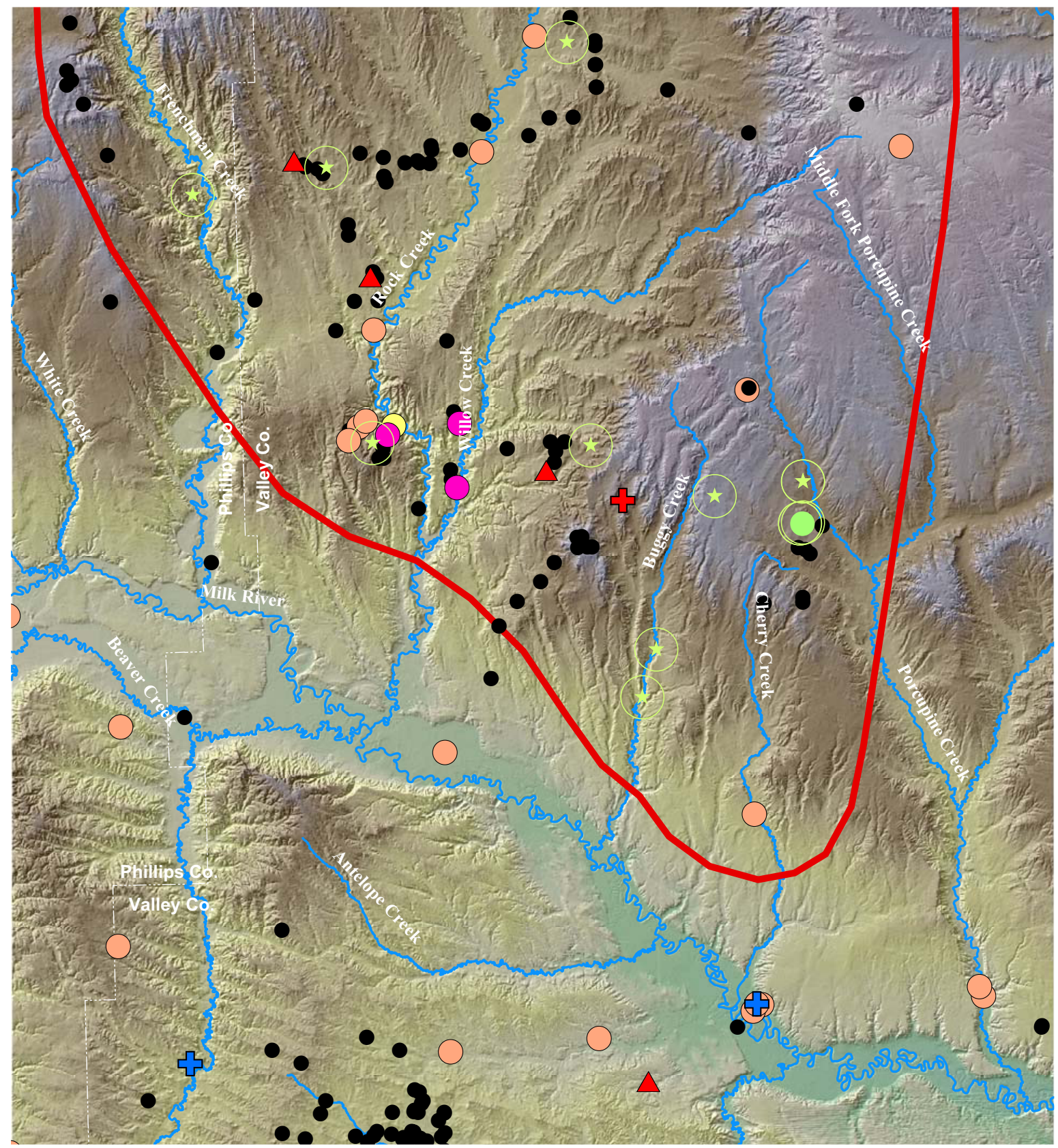

\begin{tabular}{|lll|}
\hline Bitter Creek - Frenchman Creek Study Area & & Great Plains Toad \\
Plant \& Animal Species of Concern & & Plains Spadefoot \\
Noteworthy Plant Community & & Northern Leopard Frog \\
Birds & 5 Short Horned Lizard \\
Chaffweed & 5 Western Hognose Snake \\
& $\Delta$ Prairie Dog Colony \\
\hline
\end{tabular}

0

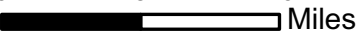


cusickii), and prairie junegrass occur with blue grama, which is the only important warmseason grass in the study area. Blue grama is able to exploit drought or other stress conditions. By comparison, eastern Montana supports greater numbers of warm-season grasses, including little bluestem (Schizachyrium scoparium), prairie sandreed (Calamovilfa longifolia), and switchgrass (Panicum virgatum).

Northern porcupine grass, as well as, needleand-thread (Hesperostipa comata) and green needlegrass characterize upland sites from the driest excessively drained sites, where needleand thread is dominant, to the ultra-mesic sites where green needlegrass is typically wellrepresented if grazing pressure is not intensive. Green needlegrass is highly palatable, moderate to highly sensitive to grazing pressure and can serve as a good indicator of past grazing intensity. Needle-and-thread grasslands are comparatively uncommon due to a scarcity of sandstone; similarly, prairie sandreed grasslands are uncommon.

The importance of thickspike wheatgrass in northern Montana has not been fully recognized prior to this inventory. We speculate that this area represents a transition from the south, where western wheatgrass is both the upland and lowland dominant, to the north, where thickspike wheatgrass is the dominant upland grassland type. Thickspike wheatgrass or bearded wheatgrass (Elymus trachycaulus) is an extensive large patch and matrix grassland type ( $>2000$ acres in size), especially where parent material is from finegrained sedimentary material or glacial drift (Appendix A). Coupland's observations (1992) also support this observation. Western wheatgrass is a major grassland type across the study area but, rather than being ubiquitous, as is the case in much of the Northwestern Glaciated Plains Section, here it is predominantly associated with alluvial terraces, floodplains, or wetland (potholes) features.

\section{Shrublands}

Shrub steppe is comparatively rare within the study area. Several small stands of Wyoming big sagebrush (Artemisia tridentata ssp. wyomingensis) are found near Buggy Creek and in uplands west of the Bitter Creek Badlands. These stands represent the northern extent of Wyoming big sagebrush (McArthur 1999) in North America. In contrast, a few miles to the south, Wyoming big sagebrush communities are a major vegetation type, however they rarely are found in the study area. Fringed sage (Artemisia frigida) is a subshrub that occasionally attains high cover in communities subject to continuous or frequent herbivory. Silver sagebrush (Artemisia cana) communities usually occur in drier positions in the riparian zone. Black greasewood (Sarcobatus vermiculatus) shrublands are uncommon communities associated with ephemeral drainages or eroded, salt-affected outcrops with thin soils.

Shrublands dominated by Juniperus horizontalis, a conspicuous low mat-forming shrub, occur on erosive substrates such as bentonite or eroded shale in the badland ecological site. We recognize five new plant associations from this study area. This relatively large increase in the number of plant associations described as new to the state indicates that northeastern Montana has received insufficient inventory to document the wide range of community types made possible by the interaction of habitat diversity and floristic richness. Steep-sided, incised draws are commonly dominated by silver buffaloberry (Shepherdia argentea) or common chokecherry (Prunus virginiana). In the Frenchman Creek watershed, sandstone outcrops are vegetated with skunkbush sumac (Rhus trilobata), a shrub type that is uncommon in the remainder of the study area. Although shrublands cover a small portion of the overall area, this habitat provides important structural diversity to the landscape. 


\section{WOODLAND}

Rocky Mountain Juniper (Juniperus scopulorum) occurs as small isolated stands on northern slopes of draws and coulees in Rock Creek Canyon. Woody draws dominated by green ash (Fraxinus pennsylvanica) and/or box elder (Acer negundo) are rare here; we found numerous individuals of both species in ravine settings, but did not document enough to constitute a community. Trembling aspen (Populus tremuloides) is very uncommon in this part of Montana. We were informed of two stands on private property in the Opheim Hills (T35N, R39E, S02 and T36N, R39E, S26) but unfortunately were not able to sample them. The persistence of aspen stands disjunct from the aspen foothills and the Missouri River Breaks suggests these are relicts worthy of further investigation.

\section{BADLANDS}

At the geographical center of the study area, the extensive Bitter Creek Badlands exhibit the most extensive dissected badlands terrain in the state and support unique vegetation types. Highly erosive soils are sculpted by water and wind into bizarre landforms. Bentonite and acid shale form eroded shale-ridge systems and slope outwash that support distinctive communities dominated by specialized, drought- and/or salt-tolerant shrubs or herbs. Among the plant communities restricted to this area are longleaf sagewort (Artemisia longifolia) and creeping juniper (Juniperus horizontalis), which is associated with erodible terrain of primarily northerly exposures with shale substrates. Creeping juniper acts as a soil stabilizer in the badlands environment.

\section{WetLand AND RIPARIAN}

Wetlands are uncommon within the BitterFrenchman Creek area. The most extensive type is palustrine (Cowardin et al. 1979), and includes herbaceous wetlands commonly referred to as wet meadows, marshes or fens, shrub dominated swamps and gallery forests. Wetlands characterized by an accumulation of organic matter are very infrequent. One noteworthy fen is located on state land in the Dry Fork Creek Landscape (Township 33N, Range 39E, Section 24); it consists of a small spring-fed wetland. Another fen, drained by a tributary of the West Fork of Porcupine Creek, occurs on state lands (Township 35N, Range $40 \mathrm{E}$, Section 36), though unfortunately it is both bisected by State Highway24 and has been heavily impacted by cattle with hummocks and noxious weeds present.

Prairie pothole wetlands in the Dry Fork Creek landscape have a predictable suite of herbdominated communities including water sedge (Carex aquatilis), clustered field sedge (Carex praegracilis) narrow spike reedgrass (Calamagrostis stricta), Baltic rush (Juncus balticus) and tufted hairgrass (Deschampsia caespitosa) as well as shrubby cinquefoil (Dasiphora floribunda) dominated shrublands. The Crow Creek wetlands are shrubdominated, some of which are salt-effected. Black greasewood and inland saltgrass (Distichlis spicata) are community dominants on salt-effected soils. Scattered throughout the study area are small constructed water reservoirs or existing ponds where the outlets are dammed to raise water levels. The extreme variation in water level encourage establishment of early seral species; as water levels lower, annuals exploit the open environment within the draw down zone.

Several streams drain this region and provide wet and moist habitats that support a diversity of communities ranging from herbaceous to forest dominated. Cottonwood (Populus deltoides) riparian forests occur along Frenchman Creek, Rock Creek, Crow Creek and Buggy Creek. The absence of red osier dogwood (Cornus sericea) and dominance of western snowberry (Symphoricarpos occidentalis), Wood's rose (Rosa woodsii), and wild current (Ribes spp.), as well as, various pasture grasses, suggest that pervasive livestock and wildlife use has reduced undergrowth diversity in cottonwood stands. 
Rock Creek is a perennial stream that has incised a relatively deep sandstone canyon. Rock Creek and a number of its tributaries support mainly shrub- and forb-dominated riparian communities. Populations of exotic/ weedy plants have degraded the condition of the riparian zone. Alluvial flats and benchlands often have extensive stands of western wheatgrass.

\section{Plant Species of Concern}

Few plants in the Bitter Creek - Frenchman Creek area are ranked as Species of Concern by the Montana Natural Heritage Program (Heidel, B. 2001). This is primarily due to the relatively short time period since the last glaciers covered these plains and the absence of unique substrates, such as sand dunes. The only plant species of concern found during our surveys was one large population of chaffweed (Centunculus minimum), a BLM Watch Species, discovered on state lands in the Dry Fork Creek landscape. This species grows in vernally wet swales, where it is associated with western wheatgrass (Pascopyrum smithii) and least spikerush (Eleocharis acicularis). Two other annual plants that inhabit drying mud around shallow ponds and wetlands are known historically from the region and may still be found there. Poison suckleyi (Suckleya suckleyana) was collected in 1900 from the Glasgow area, and scarlet ammannia (Ammannia coccinea) was reported from central Phillips County (Lake Bowdoin) in a 1903 publication.

Another Montana species of concern, the fiveleaf cinquefoil (Potentilla quinquefolia), was collected in the Opheim Hills in 1983, based on a specimen at the University of Montana herbarium ${ }^{1}$. Since this plant is typically found in montane or alpine habitats, the specimen has been sent to a specialist for verification.

Several other species are associated with plains habitats that are present in the Bitter Creek Frenchman Creek area, and should be sought in future surveys. One is hot Spring thermalis
(Phacelia thermalis), an annual plant associated with sparsely vegetated soils in grasslands and open woodlands. Another is the long-sheath water-weed (Elodea longivaginata) a perennial aquatic plant of shallow ponds and lakes.

\section{BIRDS}

The Bitter Creek-Frenchman Creek area supports a diverse avifauna that includes 16-18 breeding species considered grassland obligates (Vickery et al. 1999). Thirteen of these are considered Partners In Flight (PIF) priority grassland species for the Northern Shortgrass Prairie physiographic area (Pashley et al. 2000). Four of those (Marbled Godwit, Sprague's Pipit, Baird's Sparrow, McCown's Longspur) are essentially endemics, breeding only in the Northern Great Plains. Other PIF priority species in the Bitter Creek Frenchman Creek area include Short-eared Owl and Greater Sage-Grouse.

During the 1999 and 2000 field seasons, we identified twelve Montana bird Species of Concern/Potential Concern that are also PIF Priority I or II species (requiring conservation action or monitoring, respectively; Casey 2000) in the study area (Table 3). We also recorded eight Montana PIF Priority III species (Killdeer, Willet, Wilson's Phalarope, Shorteared Owl, Clay-colored Sparrow, Bobolink, Brewer's Blackbird, Red-winged Blackbird); Priority III species are considered at lower risk and of local concern, and are suggested for consideration in the design and selection of conservation and monitoring strategies for the region.

The upland prairie avifauna appears largely intact throughout much of the Bitter Creek Frenchman Creek study area where land has not been converted to agriculture. Species typical of grasslands are widespread, especially the small passerine Species of Concern on which we focused (Sprague's Pipit, Baird's Sparrow, Grasshopper Sparrow, McCown's Longspur, Chestnut-collared Longspur). For

${ }^{1}$ Collection by L. Thompson, 1983 
Table 3. Vertebrate Species of Concern (Carlson 2001) and Montana PIF priorities I or II documented in the Bitter Creek - Frenchman Creek study area. Asterisk (*) prior to common name indicates species was not encountered during our 1999-2000 field surveys. Species documented in landscapes of special conservation interest (see text) within the study area are indicated. Bold lettering indicates BLM Sensitive animal species.

\begin{tabular}{|c|c|c|c|}
\hline Common Name & Scientific Name & Conservation Status & Landscapes $^{1}$ \\
\hline Ferruginous Hawk & Buteo regalis & Concern; PIF I & \\
\hline Greater Sage-Grouse & Centrocercus urophasianus & $\begin{array}{l}\text { Potential Concern, } \\
\text { declining; PIF I }\end{array}$ & $3,6,7$ \\
\hline Long-billed Curlew & Numenius americanus & $\begin{array}{l}\text { Potential Concern, } \\
\text { declining; PIF II }\end{array}$ & $1,3,5$ \\
\hline Burrowing Owl & Athene cunicularia & Concern; PIF I & 1,3 \\
\hline Loggerhead Shrike & Lanius ludovicianus & $\begin{array}{l}\text { Potential Concern, } \\
\text { declining; PIF II }\end{array}$ & \\
\hline Sprague's Pipit & Anthus spragueii & Concern; PIF I & $1,3,4,5,6,7$ \\
\hline Brewer's Sparrow & Spizella breweri & $\begin{array}{l}\text { Potential Concern, } \\
\text { declining; PIF II }\end{array}$ & 7 \\
\hline Lark Bunting & Calamospiza melanocorys & $\begin{array}{l}\text { Potential Concern, } \\
\text { declining; PIF II }\end{array}$ & $1,3,7$ \\
\hline Grasshopper Sparrow & Ammodramus savannarum & $\begin{array}{l}\text { Potential Concern, } \\
\text { declining; PIF II }\end{array}$ & $1,3,5,7$ \\
\hline Baird's Sparrow & Ammodramus bairdii & Concern; PIF I & $1,3,4,5,6,7$ \\
\hline McCown's Longspur & Calcarius mccownii & $\begin{array}{l}\text { Potential Concern, } \\
\text { declining; PIF II }\end{array}$ & 3,7 \\
\hline Chestnut-collared Longspur & Calcarius ornatus & $\begin{array}{l}\text { Potential Concern, } \\
\text { declining; PIF II }\end{array}$ & $1,3,4,7$ \\
\hline Black-tailed Prairie Dog & Cynomys ludovicianus & Concern & 1,3 \\
\hline *Swift Fox & Vulpes velox & Concern & 3,7 \\
\hline *Plains Spadefoot & Spea bombifrons & Review, data deficient & 6 \\
\hline Great Plains Toad & Bufo cognatus & Concern & 6 \\
\hline Northern Leopard Frog & Rana pipiens & Concern & 6,7 \\
\hline *Short-horned Lizard & Phrynosoma hernandezi & Review, data deficient & 2 \\
\hline *Western Hognose Snake & Heterodon nasicus & Concern & \\
\hline *Flathead Chub & Platygobio gracilis & Review, data deficient & $?$ \\
\hline *Western Silvery Minnow & Hybognathus argyritis & Review, data deficient & $?$ \\
\hline *Plains Minnow & Hybognathus placitus & Review, data deficient & 6 \\
\hline
\end{tabular}

${ }_{1}^{1}$ ) Bitter Creek Badlands, 2) Buggy Creek, 3) Crow Creek, 4) Dry Fork Creek, 5) Frenchman Creek, 6) Rock Creek Canyon, 7) South Fork Rock Creek 
example, we detected Sprague's Pipit on 49 point counts (104 territorial males) and Baird's Sparrow on 30 point counts ( 77 territorial males) out of 70 total counts. Both species sang throughout the day (07:55-20:20 for Sprague's Pipit, 07:00-18:26 for Baird's Sparrow). They were found in areas with average maximum vegetation height of $28.3 \pm$ $6.7 \mathrm{~cm}$ for Sprague's Pipit and $48.7 \pm 8.3 \mathrm{~cm}$ for Baird's Sparrow. This supported our impression that Baird's Sparrow in this area tends to occupy taller and denser vegetation than Sprague's Pipit, a pattern consistent with previous studies in Saskatchewan and North Dakota (Sutter and Brigham 1998, Davis et al. 1999, Madden et al. 2000).

We detected Grasshopper Sparrow on 13 of 70 point counts, significantly $(\mathrm{G}=4.99, \mathrm{P}<0.05)$ more often in association with Baird's Sparrow (33.3\% of Baird's Sparrow locations) than Sprague's Pipit (12.2\% of pipit locations). McCown's Longspur occurred on six counts, and Chestnut-collared Longspur on 22 counts. The two longspur species are probably somewhat under-represented in our total number of point counts due to differences in the timing of their song displays and our unfamiliarity with all the nuances of their vocalizations, particularly McCown's Longspur.

\section{Mammals}

Three Black-tailed Prairie Dog colonies exist in the Bitter Creek - Frenchman Creek study area. Two of these (in T33N R37E, and T35N $\mathrm{R} 36 \mathrm{E}$ ) support large numbers of individuals and are breeding sites for Burrowing Owls. The third colony, in T36N 35E of the Crow Creek landscape, is nearly extirpated for some unknown reason. We noted only one animal and evidence of digging at two or three other mounds during our visit on 27 June 2000. No Burrowing Owls were observed at this colony during our visit. However, Burrowing Owls occupy ground squirrel and Badger (Taxidea taxus) burrows away from prairie dog colonies in the study area; e.g., we observed a pair of adults on 27 June 2000 at an old Badger burrow in T36N R36E, Sect. 32 of the Crow Creek landscape.

Swift Fox appears to have reoccupied parts of the Bitter Creek - Frenchman Creek area following releases during the last decade in Canada (Foresman 2001). Swift Foxes were live-trapped in seven Sections of four Townships during January and February 2001 (D. Waller personal communication).

\section{Amphibians}

Five amphibian and seven reptile species have been documented in the Bitter Creek Frenchman Creek study area; three amphibians and two reptiles are Montana Animal Species of Concern/Review (Table 4). During our fieldwork, we documented three amphibian species (Great Plains Toad, Boreal Chorus Frog, Northern Leopard Frog) and four reptile species (Painted Turtle, Racer, Plains Garter Snake, Western Rattlesnake), of which Great Plains Toad and Northern Leopard Frog are Species of Concern.

Only three records of Great Plains Toad are reported from the study site (in 1986, 1995, and 2000), all from T33N R36E in the Rock Creek-Willow Creek area. Northern Leopard Frog (another Species of Concern) and Plains Spadefoot (a Species on Review) are also found in this Township (Roedel and Hendricks 1998), indicating that the Rock Creek landscape supports perhaps the most diverse amphibian assemblage of the Bitter Creek Frenchman Creek area.

The few records on amphibians and reptiles in the area make it difficult to describe in any detail their distributions, and impossible to assess viability of populations, beyond noting their continuing persistence. Certain habitat features, such as sandy soils or ephemeral flood pools in riparian corridors where sandy soils are deposited, may limit distributions in the study area for Great Plains Toad, Plains Spadefoot and Western Hognose Snake, 
Table 4. Amphibians and Reptiles in the Bitter Creek - Frenchman Creek Study Area.

\begin{tabular}{lll} 
Common Name & Scientific Name & Landscapes $^{1}$ \\
\hline *Tiger Salamander & Ambystoma & 2 \\
*igrinum & \\
*Plains Spadefoot & Spea bombifrons & 6 \\
Great Plains Toad & Bufo cognatus & 6 \\
Boreal Chorus Frog & Pseudacris triseriata & $1,2,3,4,5,6,7$ \\
Northern Leopard Frog & Rana pipiens & 6,7 \\
Painted Turtle & Chrysemys picta & $1,2,5,6,7$ \\
*Short-horned Lizard & Phrynosoma hernandezi & 2 \\
*Western Hognose Snake & Heterodon nasicus & \\
Racer & Coluber constrictor & 5 \\
*Gopher Snake & Pituophis catenifer & 6 \\
Plains Garter Snake & Thamnophis radix & $4,6,7$ \\
Western Rattlesnake & Crotalus viridis & 1
\end{tabular}

${ }^{1}$ 1) Bitter Creek Badlands, 2) Buggy Creek, 3) Crow Creek, 4) Dry Fork Creek, 5) Frenchman Creek, 6) Rock Creek Canyon, 7) South Fork Rock Creek

because each is linked to this kind of soil substrate. Both amphibian species need loose soil in which to burrow, and hognose snakes are toad predators (Stebbins 1985), so the habitat distributions of each in Bitter Creek Frenchman Creek area may largely overlap.

\section{REPTILES}

Few records exist for the two reptiles Species of Concern in the area, Short-horned Lizard and Western Hognose Snake, and their status here is uncertain. Both could be widespread at low density, but more intensive survey work will be necessary to determine that. Both species are near the northern limits of their distributions (Secoy and Vincent 1976, Stebbins 1985), with the Short-horned Lizard extending into Saskatchewan only in the adjacent portions of the Frenchman Creek and Rock Creek drainages (Powell et al. 1998).

\section{FisH}

Little sampling for non-game fish has been done in the Bitter Creek - Frenchman Creek area, and we did not survey for fish during this study. B. Bramblett (personal communication) collected Plains Minnow, a state Review species, on 1 August 2000 just north of Rock Creek Canyon at the only site sampled on Rock Creek; nine additional fish species (eight native and one introduced) were present. Plains Minnow represented $4.9 \%$ of the total sample (467 fish). Other fish Species of Concern that may occur in the area include Flathead Chub and Western Silvery Minnow (Brown 1971, Holton and Johnson 1996).

\section{Exotic Plants and Noxious weeds}

Exotic species and noxious weeds are currently at low levels in the Bitter Creek - Frenchman Creek drainages, however, they represent a potential threat to the native prairie landscape. Noxious weeds frequently invade disturbed areas, and the low levels of disturbance in this area - e.g., low road density and industrial development - has kept weed establishment at relatively low levels. On the other hand, some of the more aggressive noxious weeds are known to invade natural landscapes and are especially threatening even to healthy landscapes such as this. One of the most aggressive invaders, spotted knapweed 
(Centaurea maculosa), has been found in a state owned gravel pit north of Highway $2-\mathrm{a}$ most advantageous location from which to spread; we understand every effort is being made to exterminate this population.

An equally aggressive noxious weed, leafy spurge (Euphorbia esula), is already broadly distributed throughout the study area. It has a highly efficient distribution system, via bird droppings and watercourses; especially severe infestations occur along Rock Creek. We noted leafy spurge populations associated with scattered stands of thorny buffaloberry in the Bitter Creek Badlands, due to the spurge seeds being eaten by birds (principally mourning doves) and then excreted onto favorably moist habitats within these shrub stands.

The BLM has sought to eradicate leafy spurge through the aerial application of herbicides and with biological control by release of rootfeeding flea beetles. A negative consequence of using herbicides has been the mortality of the thorny buffaloberry from herbicide drift, due to the turbulence generated by rotor blades and natural wind currents during aerial applicators. There should be low tolerance for the loss of thorny buffaloberry because it constitutes an important wildlife habitat resource, even with its limited coverage. Extra structure in the vegetation provides valuable wildlife forage, shelter from weather, and cover from predators. Two other noxious weeds, Canada thistle (Cirsium arvense) and field bindweed (Convolvulus arvensis), were noted within the study area as scattered populations that apparently do not pose a significant threat to native communities at this time.

Several other exotic species not designated as noxious weeds may pose a significant and immediate threat to these native grassland communities. Quackgrass (Agropyron repens) and reed canarygrass (Phalaris arundinacea) are exotic rhizomatous grasses that compete aggressively with native vegetation in wetland and riparian environments, and were found in several areas. Quackgrass was especially abundant on streambanks in the Frenchman Creek and South Fork Rock Creek drainages. In the Bitter Creek Badlands, we observed a sizable canarygrass population that had overtopped the native woolly sedge (Carex pellita) and tufted hairgrass community, and threatened to out-compete the native vegetation. Lesica and Merigliano (1998) demonstrated that reed canarygrass is represented in Montana by both native and exotic genetic types; we did not try to differentiate native and exotic populations. Both quackgrass and canarygrass merit reevaluation in Montana for designation as noxious weeds, as has been done in a number of other western states.

Three exotic upland grasses, crested wheatgrass (Agropyron cristatum), smooth brome (Bromus inermis), and Japanese brome (Bromus japonicus) occur within the study area. Crested wheatgrass, one of the most ecologically significant exotic plants in Valley and Phillips Counties, was widely sown for soil stabilization following the extensive failure of dryland farming in the Montana's Northern Great Plains. This species has a number of cultivars, which may explain the different responses when planted for grazing and stabilization, and in its propensity to establish off-site. Compared with native cold-season perennial grasses, crested wheatgrass seedlings establish early and develop rapidly, and once established, stands of crested wheatgrass are more tolerant of heavy grazing (West 1999). These factors contribute to its ability to outcompete native grasses and on that basis, we would caution against including crested wheatgrass in seed mixes along with native species. Though crested wheatgrass is not considered an aggressive invader, the species is capable of slowly seeding into native prairie, especially where there is disturbance. The major risk, as with introduced grasses in general, is the suppression of native species and the impoverishment of species diversity (Lesica and DeLuca 1996). 
Japanese brome is an aggressive annual that occurs as scattered populations, often where intensive grazing has occurred on alluvial terraces above streams. Smooth brome, a strongly rhizomatous perennial, has been planted as roadside cover and does not tend to expand here onto surrounding prairie.

However, where it occurs elsewhere in Montana, this species is considerably more aggressive, expanding from small founder populations to form relatively pure and dense clones.

A number of other noxious weeds occur in the vicinity and should be continuously monitored. Of the 75 exotic plants listed in the Invaders Database (Rice 2001) for Valley County, 19 are noxious, either in Montana or a neighboring state (Table 5), and are a potential threat in the Bitter Creek - Frenchman Creek area. Control of leafy spurge should continue to be a primary management objective and inventory and control of spotted knapweed should continue with great diligence.

Another exotic species with potential to harm native prairie is yellow sweet clover (Melilotus officinalis), a nitrogen-fixing plant frequently used in seed mixes for fire rehabilitation or in wildlife enhancement projects designed to improve 'dense nesting cover'. We have observed it to completely overwhelm (overtop and shade) the native species, including rhizomatous grasses, on portions of the Charles M. Russell National Wildlife Refuge. It may be appropriately seeded after disturbance in

Table 5. Noxious weeds recorded for Valley County obtained from the Invaders Database (Rice 2001). Species documented in the Bitter Creek - Frenchman Creek study area are indicated.

Negative data does not imply the weed is absent but rather, it was not noted during the inventory.

\begin{tabular}{|c|c|c|}
\hline Scientific Name & Common Name & Landscapes \\
\hline Agropyron repens & Quackgrass* & 2,7 \\
\hline Bromus inermis & Smooth brome* & $1,2,3,4,5$ \\
\hline Bromus japonicus & Japanese brome* & $1,2,4,5,6$ \\
\hline Cardaria draba & Hoary cress & \\
\hline Centaurea diffusa & Diffuse knapweed & \\
\hline Centaurea maculosa & Spotted knapweed & 8 \\
\hline Centaurea repens & Russian knapweed & \\
\hline Chrysanthemum leucanthemum & Oxeye daisy & \\
\hline Cirsium arvense & Canada thistle & $1,4,5,6$ \\
\hline Convolvulus arvensis & Field bindweed & \\
\hline Cuscuta approximata & Clustered dodder* & \\
\hline Euphorbia esula & Leafy sprurge & $1,5,6$ \\
\hline Hyoscyamus niger & Black henbane & \\
\hline Kochia scoparia & Kochia* & \\
\hline Linaria dalmatica & Dalmatian toadflax & \\
\hline Peganum harmala & African rue* & \\
\hline Phalaris arundinacea & Reed canarygrass* & 1 \\
\hline Polygonum cuspidatum & Japanese knotweed* & \\
\hline Potentilla recta & Sulfur cinquefoil & \\
\hline Tamarix Spp. (a complex) & Tamarix & \\
\hline Tanacetum vulgare & Common tansy & \\
\hline
\end{tabular}


potentially forested environments where it eventually will be shaded-out. However in grasslands, we suggest the substitution of native species, such as the scurfpeas (Pediomelum or Psoralidium, formerly Psoralea spp.) or American vetch (Vicia americana), which could be cultivated and included in seed mixes as nitrogen fixers.

\section{CONCLUSIONS AND RECOMMENDATIONS}

The Bitter Creek - Frenchman Creek region is an exceptional example of a glaciated prairie. The extent of the intact prairie and the quality of the landscape setting qualify this part of Montana as an outstanding Great Plains midgrass prairie landscape. The Dry Fork Creek area stands out as having national significance for the extensive-intact mid-grass prairie consisting of northern porcupine grass thickspike wheatgrass. This example is one of the best - if not the best - stands of its type documented in all of the US Great Plains. This grassland is managed by the Montana Department of Natural Resource Conservation and currently leased for grazing. Livestock grazing is highly compatible with natural ecological processes that maintain these grasslands, whereas plowing the grassland for agricultural production would result in a permanent loss of this important grassland.

The variable topography and vegetation in the Bitter Creek - Frenchman Creek area support diverse native animal communities typical of the northern Great Plains. The grasslands still support a complete suite of grassland-obligate birds, including Sprague's Pipit, Baird's Sparrow, Grasshopper Sparrow, McCown's Longspur, and Chestnut-collared Longspur (Table 3) - all Montana Species of Concern. These species are present because the grasslands in this region offer a mosaic grassland structure (in both density and height) where each bird species can find the foraging and nesting habitat that it requires. Other species, such as Ferruginous Hawk, are present because of the availability of preferred prey, especially ground squirrels (Spermophilus spp.) and Black-tailed Prairie Dogs (Cynomys ludovicianus).

Of particular significance to amphibians and fish is the availability of water. Riparian areas along streams, especially Rock Creek continue to support a significant native amphibian fauna, including Great Plains Toad, Northern Leopard Frog, Plains Spadefoot, and Boreal Chorus Frog. Some of these amphibian species are also attracted to stock ponds and reservoirs for breeding and over-wintering. The abundance of such wetland breeding sites in the Bitter Creek area contributes significantly to the diversity of the fauna found there (Semitsch and Bodie 1998). However, these water developments can also act as habitat sinks, where immigration exceeds emigration and deaths exceed births (Pulliam 1996), if they also expose amphibian populations to predatory non-native fish and livestock trampling (Bartelt 1998, Maxell 2000).

In addition to the water body itself, amphibians require terrestrial buffer zones extending 150200 meters from shore to protect adults during the non-breeding period (Semlitsch 1998), which in this region extends essentially yearround due to differences among species in adult reproductive behavior (Russell and Bauer 1993, Hammerson 1999). For example, adult Tiger Salamanders move to ponds in spring to breed, then depart again to burrow systems, whereas adult Northern Leopard Frogs also move to ponds in spring but may remain at them until late summer. It is also important to maintain dispersal corridors of riparian vegetation along drainage systems that allow movement of adults to new sites when ponds and other breeding habitats dry up during periods of drought or fill in through succession. Because of extensive native habitat and relatively intact landscapes in the Bitter Creek - Frenchman Creek area, barriers to adult dispersal probably do not pose a significant problem at this time. 
Distributions of amphibians and reptiles are sketchy for the area. Even less understood are small mammal diversity and habitat affinities. Additional inventory is needed in these groups; inventories should be designed to also gather data to on coarse-level responses to management practices. These data, when combined with prior work on birds, will allow managers to design best-management guidelines for the broadest suite of species.

We can offer little information at this time about the habitat requirements of this area's fish communities, except that the native fauna consists of stream-dwelling species that rely on the continued availability of flowing water from streams and springs. Additional survey of the fish communities would provide better understanding of their composition and management issues.

Recent studies have determined that some grassland birds are sensitive to habitat conversion on landscape scales, and may be area sensitive - i.e., requiring large expanses of contiguous habitat indicate. This underscores that extensive and contiguous native prairie rangelands such as the Bitter Creek Frenchman Creek study area are important to maintain large viable populations of native grassland-dependent songbirds. Baird's Sparrow and Grasshopper Sparrow in the Northern Great Plains tend to favor larger grassland patches (Johnson and Igl 2001), and their abundance in the Bitter Creek area relative to other regions of Montana reflects this (personal observation). Similar data are not available for Sprague's Pipit, McCown's Longspur, and Chestnut-collared Longspur. However, Sprague's Pipit and Chestnutcollared Longspur are much less abundant on agricultural landscapes and those planted with exotic grasses (Stewart and Kantrud 1972, Sutter and Brigham 1998, Davis et al. 1999).

Data on area sensitivity and vulnerability to habitat fragmentation are incomplete and uneven across vertebrate groups and habitats.
For example, responses of amphibians and reptiles to habitat fragmentation and conversion in shortgrass prairie are poorly studied. Therefore, many conclusions about animal responses to increasingly fragmented grasslands and prairie landscapes are speculative and inferred from habitat selection studies at local scales. One thing, however, is clear. Large unfragmented landscapes are more likely to maintain the long-term diversity of native species, because a greater array of native habitats remain available. Retention of disturbance regimes (such as fire and grazing) and processes linking species (such as predator-prey interactions and herbivory), which are necessary to sustain native habitat diversity, is most likely to occur in large intact landscapes (Harris et al. 1996).

Future studies could focus on determining responses of the grassland vertebrates to current land management practices in the Bitter Creek - Frenchman Creek area. Birds may be the best first choice for studying population responses to landscape manipulations because of documented declines in several grassland species that breed in the area (Peterjohn and Sauer 1999). Results of such studies should help managers develop best management practices (grazing in particular) for this region. For example, an ongoing study by MTNHP of grassland birds in the Bitter Creek area is documenting the relationship of grassland bird abundance to different rotational grazing practices, and how patterns in breeding abundance may result from differences in vegetation structure and pasture size. Findings from this study will help managers adjust current practices (if changes are needed) to accommodate both birds and cattle. Recent research on The Nature Conservancy's Tallgrass Prairie Preserve in Oklahoma, where the interaction of grazing and fire are used to maintain rangeland heterogeneity (Fuhlendorf and Engle 2001), may also serve as a model for maintaining biodiversity in larger intact prairie landscapes such as the Bitter Creek-Frenchman Creek area. 


\section{Literature Cited}

American Ornithologists' Union. 1998. Check-list of North American birds. $7^{\text {th }}$ edition. American Ornithologists' Union, Washington, D.C.

American Ornithologists' Union. 2000. Forth-second supplement to the American Ornithologists' Union Check-list of North American birds. Auk 117:847-858.

Bartelt, P. E. 1998. Bufo boreas (Western Toad) mortality. Herpetological Review 29:96.

Bibby, C. J., N. D. Burgess, D. A. Hill, and S. H. Mustoe. 2000. Bird census techniques. Second edition. Academic Press, London, UK.

Bingham et al. 1984. Soil Survey of Valley County, Montana. United States Department of Agriculture, Soil Conservation Service.

Booth, W. E. 1950. Flora of Montana, part 1, conifers and monocots. The Research Foundation at Montana State College, Bozeman, MT. 232 pp.

Brown, C. J. D. 1971. Fishes of Montana. Big Sky Books, Bozeman, MT.

Carlson, J. 2001. Coordinator, Montana Animal Species of Concern Committee. Montana Animal Species of Concern. Montana Natural Heritage Program and Montana Fish, Wildlife and Parks, Helena, Montana. $12 \mathrm{pp}$.

Casey, D. 2000. Partners in Flight draft bird conservation plan: Montana. Version 1.0. American Bird Conservancy, Kalispel, MT.
Cooper, S. V. and B. L. Heidel. 1999.

Biodiversity and Representativeness of Research Natural Areas on National Wildlife Refuges in Montana: Designated Ares Within Benton Lake, Charles M. Russell, Lake Mason, Medicine Lake, and Red Rocks Lakes National Wildlife Refuges. Montana Natural Heritage Program. Helena, MT. $61 \mathrm{pp}+$ app.

Cowardin, L. M., V. Carter, F. C. Golet, and E. T. LaRoe. 1979. Classification of wetlands and deepwater habitats of the United States. U.S. Department of Interior, Fish and Wildlife Service, Biological Services Program, FWS/ OBS-79/31, Washington D.C.

Coupland, R. T. 1992. Mixed Prairie. In: R. T. Coupland (Editor), Natural Grasslands: Introduction and Western Hemisphere. Elsevier, Amsterdam. pp. 151-182.

Coupland, R. T. 1950. Ecology of Mixed Prairie in Canada. Ecol. Monog. 20:271-315.

Davis, S. K., D. C. Duncan, and M. Skeel. 1999. Distribution and habitat associations of three endemic grassland songbirds in southern Saskatchewan. Wilson Bulletin 111:389-396.

DeVelice, R. et al., 1995. Plant Communities of Northeast Montana: a first approximation. Unpublished report to the Bureau of Land Management. 116 pp.

Dorn, R. D. 1984. Vascular Plants of Montana. Mountain West Publishing, Cheyenne, WY. 276 pp. 
Faber-langendoen, D. 1999. Terrestrial Vegetation of the midwestern United States. Compiled community characterization abstract in draft form. Midwest Office of The Nature Conservancy, Minneapolis, Minn.

Foresman, K. R. 2001. The wild mammals of Montana. American Society of Mammalogists Special Publication No. 12. Lawrence, KS. 278 pp.

Fuhlendorf, S. D., and D. M. Engle. 2001. Restoring heterogeneity on rangelands: ecosystem management based on evolutionary grazing patterns. BioScience 51:625-632.

Hammerson, G. A. 1999. Amphibians and reptiles in Colorado, second edition. University Press of Colorado. Niwot, CO. 484 pp.

Harris, L. D., T. S. Hoctor, and S. E. Gergel. 1996. Landscape processes and their significance to biodiversity conservation. Pp. 319-347 In Population dynamics in ecological space and time (O. E. Rhodes, Jr., R. K. Chesser, and M. H. Smith, Eds.). University of Chicago Press, Chicago, IL.

Heidel, B. L., S. V. Cooper, and C. Jean. 2000. Plant Species of Special Concern and Plant Associations of Sheridan County, MT. Montana Natural Heritage Prgram. Helena, MT. 20 pp. + app.

Heyer, W. R., M. A. Donnelly, R. W. McDiarmid, L. C. Hayek, and M. S. Foster (eds.). 1994. Measuring and monitoring biological diversity. Standard methods for amphibians. Smithsonian Institution Press, Washington, D.C.

Hitchcock and Cronquist (1973). Flora of the Pacific Northwest. University of
Washington Press, Seattle, WA. 730

pp.

Holton, G. D., and H. E. Johnson. 1996. A field guide to Montana fishes. Montana Fish, Wildlife \& Parks, Helena, MT.

Johnson, D. H., and L. D. Igl. 2001. Area requirements of grassland birds: a regional perspective. Auk 118:24-34.

Jones, J. K., Jr., D. C. Carter, H. H. Genoways, R. S. Hoffmann, D. W. Rice, and C. Jones. 1986. Revised checklist of North American mammals north of Mexico, 1986. Occasional Papers, The Museum, Texas Tech University 107:122.

Kartesz, J.T. 1999. A Synonymized Checklist and Atlas with Biological Attributes for the Vascular Flora of the United States, Canada, and Greenland. First Edition. In: Kartesz, J.T. and C.A. Meacham. Synthesis of the North America Flora, Version 1.0 North Carolina Botanical Garden, Chapel Hill, NV, August.

Knopf, F. L. 1994. Avian assemblages on altered grasslands. Studies in Avian Biology 15:247-257.

Laycock, W.A. unknown date. History of Grassland Plowing and Grass Planting of the Great Plains., 8 pp.

Lesica, P. 1987a. Medicine Lake Sandhills. Unpublished Report to The Nature Conservancy. 11 pp. + app.

Lesica, P. 1987b. Comertown Pothole Prairie. Unpublished report to The Nature Conservancy. 13 pp. + app.

Lesica, P. and T. H. DeLuca. 1996. Long-term harmful effects of crested wheatgrass on Great Plains grassland ecosystems. 
Journal of Soil and Water Conservation 51: 408-409.

Looman, J. 1982. Prairie Grasses, identifies and described by vegetative characters. Research Station, Swift Current, Saskatchewan. Agriculture Canada Pub. 1413. 244 pp.

Madden, E. M., R. K. Murphy, A. J. Hansen, and L. Murray. 2000. Models for guiding management of prairie bird habitat in northwestern North Dakota. American Midland Naturalist 144:377392.

Maxell, B. A. 2000. Management of Montana's amphibians: a review of factors that may present a risk to population viability and accounts on the identification, distribution, taxonomy, habitat use, natural history, and the status and conservation of individual species. Unpublished report to USFS Region 1. University of Montana, Wildlife Biology Program, Missoula, MT. $161 \mathrm{p}$.

McArthur, E.D., 1999. Sagebrush Systematics and Distribution. Entwistle, P. G., A. M. DeBolt, J. H. Kaltnecker, and K. Steenhof, compilers. Proceedings: Sagebrush steppe ecosystems symposium. Bureau of Land Management Publication No. BLM/ID/ PT-001001+1150, Boise, ID, USA. pp. 15-26.

Natural Resource Conservation Service. 2001. Plants Database. http.// plants.usda.gov.plants/. Data accessed in May, 2001.

Natural Resource Conservation Service. 1981. Technical Range Site Description Eastern Glaciated Plains 10-14 » Precipitation Zone. Technical Guide Section II-E-8, USDA-SCS-MT.
NatureServe, 2001, International Classification of Ecological Communities : Terrestrial Vegetation. Natural Heritage Central Databases. NatureServe, Arlington, VA.

Nesser, J. A., G. L. Ford, C. L. Maynard, and D. S. Page-Dumroese. 1997. Ecological units of the Northern Region: subsections. U.S. Department of Agriculture, Forest Service, Intermountain Research Station, General Technical Report INT-GTR369. Ogden, UT.

Olson, D. H., W. P. Leonard, and R. B. Bury (eds.). 1997. Sampling amphibians in lentic habitats. Northwest Fauna No. 4.

Pashley, D. N., C. J. Beardmore, J. A. Fitzgerald, R. P. Ford, W. C. Hunter, M. S. Morrison, and K. V. Rosenberg. 2000. Partners in Flight: conservation of the land birds of the United States. American Bird Conservancy, The Plains, VA.

Peterjohn, B. G., and J. R. Sauer. 1999. Population status of North American grassland birds from the North American Breeding Bird Survey, 19661996. Studies in Avian Biology 19:2744.

Powell, G. L., A. P. Russell, and P. J. Fargey. 1998. The distribution of the Shorthorned Lizard Phrynosoma hernandezi in Saskatchewan, Canada. Northwestern Naturalist 79:19-26.

Pulliam, H. R. 1996. Sources and sinks: empirical evidence and population consequences. Pp. 45-69 In Population dynamics in ecological space and time (O. E. Rhodes, Jr., R. K. Chesser, and M. H. Smith, Eds.). University of Chicago Press, Chicago, IL. 
Reid, M. et al. 1999. International classification of ecological communities : Terrestrial vegetation of the western United States. Report from Biological Conservation Datasystem and Working Draft of July, 1999. Association of Biodiversity Information. The Nature Conservancy, Western Resource Office, Community Ecology Group, Boulder, Co.

Richardson, R. E. and L. T. Hanson. 1977. Soil Survey of Sheridan County, Montana. USDA Soil Conservation Service (NRCS). Bozeman, MT.

Roedel, M. D., and P. Hendricks. 1998. Amphibian and reptile survey on the Bureau of land management Lewistown District: 1995-1998. Montana Natural Heritage Program, Helena, MT. 75 p.

Russell, A. P., and A. M. Bauer. 1993. The amphibians and reptiles of Alberta. University of Alberta Press. Edmonton, Alberta. 264 pp.

Secoy, D. M., and T. K. Vincent. 1976. Distribution and population status of Saskatchewan's amphibians and reptiles. Saskatchewan Department of the Environment, Regina, SK.

Semlitsch, R. D. 1998. Biological delineation of terrestrial buffer zones for pondbreeding salamanders. Conservation Biology 12:1113-1119.

Semlitsch, R. D., and J. R. Bodie. 1998. Are small isolated wetlands expendable? Conservation Biology 12:1129-1133.

Stebbins, R. C. 1985. A field guide to western reptiles and amphibians. Second edition, revised. Houghton Mifflin Co., Boston, MA.
Stewart, R. E., and H. A. Kantrud. 1972. Population estimates of breeding birds in North Dakota. Auk 89:766-788.

Sutter, G. C., and R. M. Brigham. 1998. Avifaunal and habitat changes resulting from conversion of native prairie to crested wheatgrass: patterns at songbird community and species levels. Canadian Journal of Zoology 76:869-875.

The Nature Conservancy, 1999. Ecoregional Planning in the Northern Great Plains Steppe. $181 \mathrm{pp}$.

Vickery, P. D., P. L. Tubaro, J. M. C. Silva, B. G. Peterjohn, J. R. Herkert, and R. B. Cavalcanti. 1999. Conservation of grassland birds in the Western Hemisphere. Studies in Avian Biology 19:2-26.

West, N. E., 1999. Synecology and disturbance regimes of sagebrush steppe ecosystems. Entwistle, P. G., A. M. DeBolt, J. H. Kaltnecker, and K. Steenhof, compilers. Proceedings: Sagebrush steppe ecosystems symposium. Bureau of Land Management Publication No. BLM/ID/ PT-001001+1150, Boise, ID, USA. pp. 15-26.

Western Region Climate Center. 2001. Montana climate summaries. http:// www.wrcc.dri.edu/summary/ climsmmt.html. Data accessed in May, 2000 . 


\section{Appendix A: Rangeland Ecological Sites and Plant Associations}

Range Ecological Sites and Plant Associations

Brown Glaciated Plains (MLRA 52); 10-14 inch precipitation zone

\begin{tabular}{|c|c|c|c|}
\hline \multirow{2}{*}{$\begin{array}{l}\text { Ecological Site } \\
\text { Types }\end{array}$} & \multicolumn{3}{|c|}{ Plant Associations Found Within Representative Landscapes } \\
\hline & Dry Creek Landscape & Bitter Creek Badlands Landscape & Crow Creek Landscape \\
\hline $\begin{array}{l}\text { Riparian }^{1} \\
\text { Subirrigated }\end{array}$ & Western snowberry & $\begin{array}{l}\text { Thorny buffaloberry } \\
\text { Western snowberry }\end{array}$ & Western snowberry \\
\hline $\begin{array}{l}\text { Riparian }^{2} \\
\text { Meadow }\end{array}$ & $\begin{array}{l}\text { Tufted hairgrass } \\
\text { Foxtail barley } \\
\text { Common cattail }\end{array}$ & $\begin{array}{l}\text { Tufted hairgrass } \\
\text { Foxtail barley }\end{array}$ & $\begin{array}{l}\text { Tufted hairgrass } \\
\text { Foxtail barley }\end{array}$ \\
\hline Subirrigated $^{3}$ & Western wheatgrass - (Needleleaf sedge) & & Western wheatgrass - (Needleleaf sedge) \\
\hline Saline Lowland ${ }^{4}$ & $\begin{array}{l}\text { Foxtail barley } \\
\text { Western wheatgrass - Sandberg's bluegrass } \\
\text { Western wheatgrass - Inland saltgrass } \\
\text { Western wheatgrass - Spike-rush. }\end{array}$ & $\begin{array}{l}\text { Black greasewood / Western wheatgrass (Thickspike } \\
\text { wheatgrass) } \\
\text { Foxtail barley } \\
\text { Western wheatgrass - Inland saltgrass }\end{array}$ & $\begin{array}{l}\text { Foxtail barley } \\
\text { Western wheatgrass - Sandberg's bluegrass } \\
\text { Western wheatgrass - Inland saltgrass }\end{array}$ \\
\hline Wet Meadow $^{5}$ & $\begin{array}{l}\text { Clustered field sedge } \\
\text { Water sedge } \\
\text { Woolly sedge - Narrow-spiked reedgrass } \\
\text { Tufted hairgrass } \\
\text { Alkali cordgrass } \\
\text { Common cattail }\end{array}$ & $\begin{array}{l}\text { Clustered field sedge } \\
\text { Tufted hairgrass } \\
\text { Alkali cordgrass }\end{array}$ & Tufted hairgrass \\
\hline
\end{tabular}




\begin{tabular}{|c|c|c|c|}
\hline \multirow{2}{*}{$\begin{array}{l}\text { Ecological Site } \\
\text { Types }\end{array}$} & \multicolumn{3}{|c|}{ Plant Associations Found Within Representative Landscapes } \\
\hline & Dry Creek Landscape & Bitter Creek Badlands Landscape & Crow Creek Landscape \\
\hline
\end{tabular}

\begin{tabular}{|c|c|c|c|}
\hline $\begin{array}{l}\text { Closed } \\
\text { Depression }^{6}\end{array}$ & $\begin{array}{l}\text { Western snowberry } \\
\text { Tufted hairgrass } \\
\text { Foxtail barley } \\
\text { Western wheatgrass - (Needleleaf sedge) } \\
\text { Western wheatgrass - Spike-rush }\end{array}$ & $\begin{array}{l}\text { Western snowberry } \\
\text { Tufted hairgrass } \\
\text { Foxtail barley }\end{array}$ & $\begin{array}{l}\text { Western snowberry } \\
\text { Tufted hairgrass } \\
\text { Foxtail barley } \\
\text { Western wheatgrass - (Needleleaf sedge) } \\
\text { Western wheatgrass - Spike-rush }\end{array}$ \\
\hline Overflow $^{7}$ & $\begin{array}{l}\text { Silver sagebrush / Thickspike wheatgrass } \\
\text { Silver sagebrush / Western wheatgrass } \\
\text { Thickspike wheatgrass - Green needlegrass } \\
\text { Western wheatgrass - Green needlegrass } \\
\text { Northern Porcupine grass - (Thickspike } \\
\text { wheatgrass) }\end{array}$ & $\begin{array}{l}\text { Thorny buffaloberry } \\
\text { Silver sagebrush / Western wheatgrass } \\
\text { Creeping juniper / Thickspike wheatgrass - Green } \\
\text { needlegrass } \\
\text { Creeping juniper / Northern porcupine grass - } \\
\text { Thickspike wheatgrass } \\
\text { Thickspike wheatgrass - Green needlegrass } \\
\text { Western wheatgrass - Green needlegrass }\end{array}$ & $\begin{array}{l}\text { Silver sagebrush / Thickspike wheatgrass } \\
\text { Silver sagebrush / Western wheatgrass } \\
\text { Skunkbush sumac / Thickspike wheatgrass - } \\
\text { Green needlegrass } \\
\text { Thickspike wheatgrass - Green needlegrass } \\
\text { Western wheatgrass - Green needlegrass } \\
\text { Thickspike wheatgrass - Bearded wheatgrass }\end{array}$ \\
\hline
\end{tabular}

\begin{tabular}{|l|l|l|}
\hline Sandy $^{9}$ & & Prairie sandreed - Sun sedge \\
\hline
\end{tabular}

\begin{tabular}{|l|l|}
\hline Silty $^{10}$ & $\begin{array}{l}\text { Thickspike wheatgrass - Green needlegrass } \\
\text { Thickspike wheatgrass - Needle-and-thread } \\
\text { Western wheatgrass - Green needlegrass }\end{array}$ \\
& $\begin{array}{l}\text { Western wheatgrass - Needle-and-thread grass } \\
\text { Northern Porcupine grass - (Thickspike } \\
\text { wheatgrass) }\end{array}$ \\
\hline
\end{tabular}

Creeping juniper /Thickspike wheatgrass - Green
needlegrass
Thickspike wheatgrass - Green needlegrass
Thickspike wheatgrass - Needle-and-thread

Creeping juniper /Thickspike wheatgrass - Green needlegrass

Thickspike wheatgrass - Needle-and-thread

wheatgrass)
Silver sagebrush / Needle-and-thread

Needle-and-thread - Blue grama -

Threadleaved sedge \begin{tabular}{|l|l}
\hline Clayey $^{11}$ & $\begin{array}{l}\text { Western wheatgrass - Blue grama grass } \\
\text { Western wheatgrass - (Needleleaf sedge) } \\
\text { Thickspike wheatgrass - Prairie junegrass }\end{array}$ \\
\hline
\end{tabular}

Thin Hilly $^{12}$

Western wheatgrass - Blue grama grass

Western wheatgrass - Blue grama grass

Western wheatgrass - (Needleleaf sedge)

Thickspike wheatgrass - Needle-and-thread

Thickspike wheatgrass - Bearded wheatgrass

Thickspike wheatgrass - Green needlegrass

Creeping juniper / Thickspike wheatgrass

Creeping juniper / Bearded wheatgrass 


\begin{tabular}{|c|c|c|c|}
\hline \multirow{2}{*}{$\begin{array}{l}\text { Ecological Site } \\
\text { Types }\end{array}$} & \multicolumn{3}{|c|}{ Plant Associations Found Within Representative Landscapes } \\
\hline & Dry Creek Landscape & Bitter Creek Badlands Landscape & Crow Creek Landscape \\
\hline Pan Spots ${ }^{14}$ & & Few-flowered wild buckwheat - Broom snakeweed & $\begin{array}{l}\text { Few-flowered wild buckwheat - Broom } \\
\text { snakeweed }\end{array}$ \\
\hline Badlands $^{15}$ & & $\begin{array}{l}\text { Gardner's saltsage / Rillscale } \\
\text { Few-flowered wild buckwheat - Broom snakeweed } \\
\text { Creeping juniper / Prairie sandreed } \\
\text { Creeping juniper / Little bluestem } \\
\text { Black greasewood / Western wheatgrass (Thickspike } \\
\text { wheatgrass) } \\
\text { Longleaf sagewort }\end{array}$ & $\begin{array}{l}\text { Few-flowered wild buckwheat - Broom } \\
\text { snakeweed } \\
\text { Longleaf sagewort }\end{array}$ \\
\hline
\end{tabular}

Plant associations not occurring in any of the three landscapes listed above but referenced to a Ecological Site by superscript: Rocky Mountain juniper / Smallseeded ricegrass ${ }^{7}$, Plains cottonwood / Western snowberry, Wyoming big sagebrush / Thickspike wheatgrass, Common chokecherry ${ }^{1,7}$, Skunkbush sumac / Thickspike wheatgrass - Green needlegrass ${ }^{12}$, Skunkbush sumac / Little bluestem, Coyote willow ${ }^{1}$, Prairie sandreed - Needle-and-thread ${ }^{8}$, Plains reedgrass, Woolly sedge - Narrow-spiked reedgrass ${ }^{2,5}$, Sandberg's bluegrass - Prairie junegrass ${ }^{11:}$ 


\section{Appendix B: Landscape Site Descriptions BITTER CREEK BADLANDS LANDSCAPE}

\section{Directions}

Note: Portions of this site are located on private land and landowner permission is required to access these areas. The Bitter Creek Badland is located in northwestern Valley County, north-northwest of Glasgow, Montana. From Glasgow, take State Highway 2, 19 miles west to the intersection with Vandalia and Britsch county roads. Take Britsch Road northward for approximately 12.5 miles to the intersection with the county road heading westerly toward Ada and Abey Reservoirs. This places one at the southern extent of the Bitter Creek Badland. Continuing north-northeast on Britsch road permits access to the western perimeter of the badlands and to several poor-quality roads that traverse the area in a mostly east-west fashion.

\section{Description}

This site is characterized as a badlands environment where intricate stream dissection has resulted in topography distinguished by a fine drainage network, high drainage densities and short, steep slopes with narrow interfluves. A relatively distinct "rim" or shallow escarpment defines the eastern, southern and northern perimeter of the area. Looking west from the eastern rim, the badlands seem contained in a broad, shallow, gently tilted bowl dissected with an intricate profusion of hillocks, narrow ridges and bentonitic ballons, all separated by narrow alluvial flats. At the badland's downstream end, streams have coalesced and broader alluvial flats result. The prevailing aspect is one of an intricate patchwork of raw dull gray exposed substrate and patches of vegetation, with the denser and more extensive vegetation confined to north- and east-facing exposures. Due to extreme topographic dissection there are no matrix communities; most communities are small patch and even fragmentary.

This unique geologic area supports a number of unusual communities. Those dominated by Juniperus horizontalis (creeping juniper) appear to function as primary colonizers of high erodible protected slopes; these include types with Elymus lanceolatus - Nassella viridula (thickspike wheatgrass - green needlegrass) or Hesperostipa curtiseta - Elymus lanceolatus (porcupine grass - thickspike wheatgrass), drier exposures with high erosion rates exhibit Schizachyrium scoparium (little bluestem). Colluvial and alluvial settings with Juniperus horizontalis frequently include Calamovilfa longifolia (prairie sandreed), Juncus balticus (Baltic rush), or Elymus trachycaulus (bearded wheatgrass).

Shepherdia argentea (thorny buffaloberry) small patch communities are found tucked into protected positions, drainage heads, swales and toeslopes receiving subsurface moisture; these communities are magnets for wildlife and consequently also foci for Euphorbia esula (leafy spurge) populations. The riparian and floodplain environments support typical communities such as Deschampsia cespitosa (tufted hairgrass)- and Juncus balticus (Baltic rush). Pascopyrum smithii (western wheatgrass) is most abundant on the first terrace above intermittent streams. On salt-affected sites the Pascopyrum smithii Distichlis spicata (western wheatgrass - inland saltgrass) association is common. Sites with or influenced by bentonite, support sparse vegetation ( $<10 \%$ cover) dominated by Artemisia longifolia (longleaf sagewort) or Atriplex gardneri / Atriplex suckleyi (Gardner's saltsage / rillscale) and acid shales also tend to support depauperate communities often characterized by the Eriogonum pauciflorum - Gutierrezia sarothrae (few-flowered wild buckwheat - broom snakeweed) association.

\section{Key Environmental Factors}

Within this landscape the primary driving force of plant community patterns and composition is geological substrate where erosion, predominantly by water but also via wind, is the dominant landscape process. This landscape is a product of wind and water erosion of the susceptible members of the 
Bearpaw Shale, Judith River and Kcl Formations. The Bearpaw Shale dominates and erodes to outcrops of fissile and non-fissile bentonite shales, and thick beds of dark gray to brown bentonite. The fissile shale initially weathers to sand-sized shards and the soils are consequently "sandy" and well drained; some exposed strata have a very acidic reaction $(\mathrm{pH}<5.0)$. Pleistocene age glacial drift has largely been eroded and now exists as Quaternary alluvial deposits mixed with the eroded shales. Because upslope erosion is active, there is little soil development anywhere.

\section{Biodiversity Significance}

This site supports a diverse avifauna with seven species recognized as high priority by Montana Partners in Flight (PIF) grassland species. Priority I species include the Ammodramus bairdii, (Baird's sparrow), Anthus spragueii, (sprague's pipit), and Athene cunicularia (burrowing owl); Priority II species include the Numenius americanus (long-billed curlew), Calamospiza melanocorys (Lark bunting), Ammodramus savannarum (grasshopper sparrow) and the Calcarius ornatus (Chestnutcollared Longspur). Amphibians and reptiles have also been documented in this site; these include the Pseudacris triseriata (boreal chorus frog), Chrysemys picta (painted turtle) and the Crotalus viridis (western rattlesnake). A Cynomys ludovicianus (black-tailed prairie dog) colony is also found in this site.

\section{Other Values}

The convoluted topography offers abundant hiding cover for wildlife, and the Shepherdia argentea (thorny buffaloberry) stands provides both hiding and thermal cover for ungulates and habitat for numerous bird species. Fossilized bones protrude in several of the bentonite outcrops; two bentonite sites have been partially excavated ostensibly in the quest for these skeletal remains.

\section{Land Use}

The Bitter Creek Badlands is a wilderness study area and has been nominated by the BLM as an Area of Critical Environmental Concern. The site is within a livestock allotment; stock ponds for livestock watering have been developed along the stream bottoms.

\section{Exotics}

Currently the major invader in this landscape is Euphorbia esula (leafy sprurge). The mesic nature of Shepherdia argentea stands (and Symphoricarpos occidentalis stands to a much lesser degree) are excellent habitat for leafy spurge and constitute invasion sites/dispersal points for this weed since its seeds are eaten by various bird species and then defecated from perches. Cirsium arvense (Canada thistle) occurs sporadically in mesic to wet sites that probably experienced past livestock disturbance. Bromus japonicus (Japanese brome) is very sporadically distributed on upland sites. Bromus inermis (smooth brome) and Melilotus officinalis (yellow sweet clover), though not considered weeds, are aggressive colonizers and have scattered populations tucked away at the head of several drainages with Melilotus officinalis being somewhat more broadly, though lightly, distributed across the mesic grasslands as well.

\section{Information Needs}

This is an expansive and complex landscape and current inventory is fragmentary with only easily accessible portions of the area receiving attention.

\section{Management Needs}

Managers have recognized the potential threat posed by noxious weeds, especially Euphorbia esula (leafy sprurge) and have been diligent about controlling it. The BLM has sought to eradicate leafy 
spurge through the aerial application of herbicides and by releasing species-specific herbivorous beetles. Herbicide applications have mostly, and understandably, been by helicopter and unfortunately, this broad-brush approach has led to high mortality in the Shepherdia argentea (thorny buffaloberry) stands. This loss combined with natural mortality (or at least die-back of larger stems) has placed Shepherdia argentea in some jeopardy and considerably diminished its value as a focus for wildlife. 


\section{BUGGY CREEK LANDSCAPE}

\section{Directions}

Note: Portions of this site are located on private land and landowner permission is required to access these areas. The southern end of the Buggy Creek Landscape is located about 12 air miles northwest of Glasgow, MT. The site is most easily reached by traveling west from Glasgow on State Highway 2 approximately 10.5 miles. Take a north-bearing county road that leads directly to and through the Cornwell Property; this county road intersects Highway 2 between Sections 23 and 24 of Township 30 $\mathrm{N}$ and Range $38 \mathrm{E}$. Take the county road north about 1.7 miles to where it drops into and crosses Alkali Creek (on Cornwell ranch among outbuildings) and heads up onto the benchlands. The county road then parallels Alkali Creek to the north, approximately in the center of the Buggy Creek Landscape, and if followed for approximately 8 to 8.5 miles to Section 2 of T $32 \mathrm{~N}, \mathrm{R} 38 \mathrm{E}$ will branch; the west fork fords Buggy Creek and traverses the heart of this landscape.

\section{Description}

The Buggy Creek Landscape is characterized as rolling glaciated plains through which Buggy Creek and its tributaries have cut through to form floodplains and low terrace landforms. On the floodplains of the downstream portion of Buggy Creek Landscape Populus deltoides / Symphoricarpos occidentalis (plains cottonwood / western snowberry), Symphoricarps occidentalis, Artemisia cana / Elymus lanceolatus - Nassella viridula (silver sagebrush / thickspike wheatgrass - green needlegrass), Pascopyrum smithii (western wheatgrass) and Deschampsia cespitosa (tufted hairgrass) occur in a complex mosaic of small - to large-patch communities. These representations are among the best developed of riparian communities within the greater study area. Upstream (on Buggy Creek) floodplains have appreciable amounts of Pascopyrum smithii - Poa secunda (western wheatgrass Sandberg's bluegrass) with lesser amounts of Pascopyrum smithii - (Carex duriuscula) (western wheatgrass - (needleleaf sedge)), the later found in small swales. Pascopyrum smithii - Distichlis spicata (western wheatgrass - inland saltgrass) is found on salt-affected sites. Salix exigua (sandbar willow) is dominant in narrow streamside riparian zones.

Rolling uplands are a mix of common midgrass matrix communities, usually dominated by Pascopyrum smithii or Elymus lanceolatus (thickspike wheatgrass) with Hesperostipa comata (needle-and-thread) and Bouteloua gracilis (blue grama) as accessory species. Swales, and protected north facing slopes may have the Hesperostipa curtiseta - (Elymus lanceolatus) (northern porcupine grass - (thickspike wheatgrass)) association. Sites of higher moisture status contain Elymus lanceolatus - Nassella viridula (thickspike wheatgrass - green needlegrass). Conversely, the Hesperostipa comata - Bouteloua gracilis association is found where grazing has been intensive for extended periods, where the sod was once plowed or where soils are coarser-textured; these places often include a sod-like cover of Selaginella densa (dense spikemoss).

\section{Key Environmental Factors}

Buggy Creek and its tributaries course through primarily gently rolling plains and the hydrology of this system is still intact with no dams or diversions so that seasonal flooding is an annual event, baring drought conditions. This flooding is the primary factor in establishing new populations of Populus deltoides (plains cottonwood) and Salix spp. (willow). Much of this landscape is composed of Bankhead-Jones Lands (BLM administered) and as such is likely to have been ploughed. In this arid environment plant succession is relatively slow and some part of this landscape are obviously recovering from this physical disturbance. 


\section{Biodiversity Significance}

The tiger salamander (Ambystoma tigrinum), boreal chorus frog (Pseudacris triseriata), painted turtle (Chrysemys picta) and short-horned lizard (Phrynosoma hernandezi) have been reported from this site.

\section{Other Values}

A BLM in partnership with private landowners has made Buggy Creek riparian zone a management priority. Though neither community nor species rarity has been documented, the landscape is quite exemplary of the northern glaciated plains, possibly representing the transition area between Elymus lanceolatus (thickspike wheatgrass) and Hesperostipa curtiseta (northern porcupine grass) dominance to the north (Hesperostipa curtiseta on loamy soils, mostly Mollisols) and Pascopyrum smithii (western wheatgrass) dominance increasing to the south.

\section{Land Use}

The predominate landuse activities include ranching, farming and to a lesser extend, recreation. A considerable portion of this landscape is privately held, especially the productive floodplains but, a cursory examination showed most of the landscape to be in good ecological condition, regardless of ownership.

\section{Exotics}

The uplands appear to be in good condition with regard to noxious weeds and even increaser species, with the exception of Selaginella densa (dense spikemoss). Agropyron repens (quackgrass) populations were found immediately adjacent to steam courses and two alien pasture grasses, Bromus inermis (smooth brome) and Poa pratensis (Kentucky bluegrass) have become well established in the riparian zone and also in upland swales.

\section{Information Needs}

This landscape was minimally inventoried in 1999 and 2000, we suspect much more species, and community diversity exists than has been accounted for to date. Additional inventory in the wetland and riparian areas is recommended, especially for Scirpus spp. or Schoenoplectus spp. (bulrushes), Eleocharis spp. (spikerushes), Carex spp. (sedges), Hordeum spp. (wild barleys), and Salix spp. (willows) dominated communities.

\section{Management Needs}

Beyond carefully managing the riparian zone to ensure the protection of values associated with this easily degraded system and the monitoring of weed populations, there is no immediate management concern. Several parcels supporting Hesperostipa curtiseta - Elymus lanceolatus (northern porcupine grass - thickspike wheatgrass) and somewhat more extensive examples of the Elymus lanceolatus Nassella viridula (thickspike wheatgrass - green needlegrass) association could be viewed as candidates for planting to cereal crops with landscape fragmentation resulting; but their limited size should preclude such development. 


\section{CROW CREEK LANDSCAPE}

\section{Directions}

Note: Portions of this site are located on private land and landowner permission is required to access these areas. This site is an extensive tract that is composed almost wholly of BLM holdings (about half unbroken and half Bankhead-Jones lands) and encompasses a large portion of the Crow Creek drainage. The area is most conveniently accessed by heading north on paved State Route 537, which becomes an unpaved county road (Hinsdale North Rd.), and following it approximately 28 miles to the junction with Duncan Rd., which bears north-northwest up the main branch of Crow Creek. The more eastern portion of the site, in the Black Calf Reservoir vicinity, can be accessed via the secondary county road branching north from Hinsdale Rd. two tenths of a mile east of the Ichpair Creek crossing.

\section{Description}

This site is primarily a rolling glaciated landscape covered with a thin mantle of glacial till, through which three primary, though intermittent, streams have cut to give a northwest to southeast lineation to the low ridge system. There is generally about 200 to 250 feet of relief between the floodplains and the ridge crests. Soils originate from shale and siltstone parent material. The prominent soil series include Phillips, Scobey, Elloam, Sunburst and Thoeny; these all are fine-textured and montmorillonitic reflecting their sedimentary origins. Aridisols are most common with Mollisols and Entisols occupying much less area. Upland vegetation is preponderantly Elymus lanceolatus - Hesperostipa comata (thickspike wheatgrass - needle-and-thread), an association found on nearly all exposures. Northerly or protected exposures are typified by Hesperostipa curtiseta - (Elymus lanceolatus) (northern porcupine grass (thickspike wheatgrass)), Elymus lanceolatus - Nassella viridula (thickspike wheatgrass - green needlegrass) and most notably by Elymus trachycaulus (bearded wheatgrass)-dominated associations. On lowlands with heavier-textured soils (floodplains and terraces) a variety of Pascopyrum smithii (western wheatgrass)- or Elymus lanceolatus-dominated associations, occurs foremost among which are Pascopyrum smithii and Pascopyrum smithii - Carex duriuscula (western wheatgrass - (needleleaf sedge) herbaceous vegetation. On stream terraces the most common shrub is Artemisia cana (silver sagebrush) with undergrowth dominated by either Elymus lanceolatus or Pascopyrum smithii with Nassella viridula ranging from an important component to non-existent, largely depending on grazing intensities. Juniperus horizontalis (creeping juniper) seems to be rather strongly associated with erosive slopes or flats. It is found in combination with a number of diagnostic graminoids the most common include Schizachyrium scoparium (little bluestem) and Elymus trachycaulus (bearded wheatgrass). Schizachyrium scoparium - Carex inops ssp. heliophila (little bluestem - sun sedge) is also a common community on erosive substrates. Eroding slopes and flats that weather to acidic reaction support sparse vegetation with Eriogonum pauciflorum - Gutierrezia sarothrae (few-flowered wild buckwheat - broom snakeweed) and Artemisia longifolia (longleaf wormwood).

\section{Key Environmental Factors}

This landscape is exemplary of the Northern Glaciated Plains, with no extraordinary abiotic factors at play. There are minor outcrops of highly erosive formations, some acidic in nature, that weather to azonal soils and support unusual vegetation types. The diagnostic grasses, Elymus trachycaulus (bearded wheatgrass) and Hesperostipa curtiseta (northern porcupine grass), occur in large patches; within the Bitter Creek study area this is as far west as these species occur as community dominants. It is unknown whether this distribution is more attributable to climate or soils, or simply to chance patterns of distribution.

\section{Biodiversity Significance}


This site includes at least one prairie dog colony, although only one animal was observed in 2000 . A pair of adult burrowing owls were observed at an old Badger burrow. No plant species of special concern were identified. There are good to excellent condition examples of Elymus lanceolatus Hesperostipa comata - (Elymus lanceolatus) (needle-and-thread - (thickspike wheatgrass)) Herbaceous Vegetation.

\section{Other Values}

There are both broad expanses and small patches of Elymus lanceolatus - Hesperostipa comata (thickspike wheatgrass - needle-and-thread), in high ecological condition; this high condition probably reflects a prudent grazing regime.

\section{Land Use}

Livestock grazing, principally cattle, is the primary land use.

\section{Exotics}

No noxious weeds were documented, though exotic pasture grasses Bromus inermis (smooth brome) and Poa pratensis (Kentucky bluegrass)) are broadly distributed.

\section{Information Needs}

Much of this landscape has not been inventoried for plant and animal species of concern; the list of plant community types is almost certainly underrepresented as well. The Bankhead-Jones lands received no walk-through and only minimal assessment from vehicle or roadside observation.

\section{Management Needs}

No immediate needs were identified. 


\section{DRY FORK CREEK LANDSCAPE}

\section{Directions}

This site represents an extensive tract of state land immediately west of Fort Peck Indian Reservation that encompasses approximately 114 sections $(69,087$ acres) and is drained by Dry Fork Creek. The West Fork of Porcupine Creek forms the eastern boundary. The site is conveniently accessed by driving north on State Highway 24, approximately 24.3 miles from the junction of State Highway's 2 and 24 (about 1.4 miles east of Glasgow, MT). Near the intersection of sections 7, 8, 17, and 18 in Township $32 \mathrm{~N}$, bear north on a dirt road. This road eventually follows the eastern and western perimeters of the site, with a branch road to the north that penetrates to the lands drained by the West Fork of Porcupine Creek.

\section{Description}

Rolling upland hills dominate this site wherein are scattered a few shallow basins ringed with emergent vegetation, and at least one spring with peatland development. The uplands, especially where silty soils predominate, support a relatively unbroken expanse of Hesperostipa curtiseta - (Elymus lanceolatus) (Northern porcupine grass - (thick-spike wheatgrass)) herbaceous vegetation. On soils with less water holding capacities Elymus lanceolatus in combination with Hesperostipa comata (needle-and-thread) or/and Carex stenophylla (narrow-leafed sedge) and Carex filifolia (thread-leaved sedge) comprise the dominant vegetation. Sites with sandier soils tend to support Hesperostipa comata -dominated communities. Two intermittent streams, the West Fork of Porcupine Creek and Dry Fork Creek, drain most of the area and have very narrow, if any, associated riparian stringers. Only two of the numerous basin wetlands were examined and found to be dominated by the Eleocharis acicularis (needle spike-rush) community type; this forms nearly pure stands in the wettest portions of the wetland. Pascopyrum smithii (western wheatgrass) and Eleocharis palustris (common spikesedge) are important members of the community in the drawdown zone. Near the spring, perhaps where upwelling occurs and peat has accumulated, the wettest community is dominated by dense tussocks of Carex aquatilis (water sedge), Carex praegracilis (clustered field sedge) and Deschampsia cespitosa (tufted hairgrass). These species generally constitute not more than $10 \%$ canopy cover. Slightly drier spring-associated vegetation is dominated by the Deschampsia .cespitosa plant association wherein Juncus balticus (Baltic rush) is an important co-dominant species.

\section{Key Environmental Factors}

This site is typical of Northern Glaciated Plains environments, though glacial till only thinly mantles the landscape. Soils, predominantly fine sandy loams, appear to be derived from residuum. Where fines have collected in very shallow basins lined with clays, water sits for considerable periods, creating emergent wetlands with very little open water.

\section{Biodiversity Significance}

This landscape harbors by far the most extensive and highest quality example of the Hesperostipa curtiseta - (Elymus lanceolatus) (Northern porcupine grass - (thickspike wheatgrass)) association in the U. S. Though traversed by a limited road system and grazed by domestic stock, the whole Dry Creek Landscape is functionally intact: Its size makes it the single best example of a formally extensive and highly productive landscape mosaic before widespread conversion to agriculture. A large population of Centunculus minimus (chaffweed), a plant species of concern is found within a wetland in this site.

This site supports at least three grassland species recognized as high priority by Montana Partners in Flight (PIF). Priority I species include the Ammodramus bairdii, (Baird's sparrow), Anthus spragueii, 
(sprague's pipit); Priority II species include Calcarius ornatus (Chestnut-collared Longspur).

Amphibians and reptiles have also been documented in this site; these include the Pseudacris triseriata (boreal chorus frog) and Thamnophis radix (Plains garter snake).

\section{Land Use}

Current land use is primarily cattle ranching.

\section{Exotics}

Cirsium arvense (Canada thistle) was the only noxious weed noted in this landscape, though others may exist.

\section{Information Needs}

Resconstructing the grazing history in consultation with soil scientists might shed light on why the Hesperostipa curtiseta - (Elymus lanceolatus) association dominates here and not on adjacent lands.

\section{Management Needs}

Current management efforts preserve the dominant upland and wetland communities. Some cattle trampling and hummocking has occurred around the vicinity of the wetlands and the timing of cattle access to water sources should be considered to avoid early season use. 


\section{FRENCHMAN CREEK LANDSCAPE}

\section{Directions}

Note: Portions of this site are located on private land and landowner permission is required to access these areas. The southern boundary of the Frenchman Creek Landscape is located about 44 air-miles northwest of Glasgow, MT. From Hinsdale on U.S. Route 2 take Valley County Road 537 (Hinsdale North Road) north for 23 miles to the intersection with Genevieve Road and bear west for two miles to the intersection with Cache Creek Road. Bear north on Cache Creek Road for one mile to the intersection with Frenchman Road and then proceed generally north-northwest on Frenchman Road as it accesses the ever more deeply entrenched canyon. Approximately 6.5 miles north of the intersection of Frenchman and Cache Creek Roads a poorly maintained dirt road climbs to the west, out of the Frenchman Creek Canyon, and onto a dissected plateau that characterizes of much of the upslope portion of the landscape.

\section{Description}

Frenchman Creek is a major perennial creek draining breaklands and rolling prairie and hills characteristic of the northern glaciated plains landscape. This landscape differs from some adjacent lands to the west and south by having a minimal extent of soils appropriate for the cultivation of cereal grains. Riparian areas along Frenchman Creek inventoried in the southern end of this site support a mix of Artemisia cana (silver sagebrush)-, Pascopyrum smithii (western wheatgrass)-, Symphoricarpos occidentalis (western snowberry)- and Populus deltoides (plains cottonwood)- dominated community types. Artemisia cana / Pascopyrum smithii is perhaps the most extensive bottomland community in this stretch. Further upstream the alluvial bottoms have been extensively converted to hay meadows. Within the breaklands the uppermost sedimentary strata has a coarse texture that supports Rhus trilobata (skunkbush sumac)-dominated communities; those with Elymus lanceolatus (thickspike wheatgrass) have not been elsewhere described. The lower slopes and/or finer textured (more erosive) substrates often have Juniperus horizontalis (creeping juniper) with different graminoids present on a catena of increasing available moisture; these being Schizachyrium scoparium (little bluestem), Elymus lanceolatus (thickspike wheatgrass) and Elymus trachycaulus (bearded wheatgrass). The rolling prairie is dominated by the matrix association Elymus lanceolatus - Hesperostipa comata (needle-and-thread) or its variant, Pascopyrum smithii (western wheatgrass). Sites with above average moisture, swales and protected locations support communities dominated by Elymus lanceolatus and co-dominated by Nassella viridula (green needlegrass) or Elymus trachycaulus, and Symphoricarpos occidentalis Shrublands. Heavy soils are Pascopyrum smithii dominated (often with Carex duriuscula (needleleaf sedge) as an important co-dominant species). Sites most likely to have been plowed have a very depauperate, if any, cover of wheatgrass species and should be characterized as belonging to the Hesperostipa comata - Bouteloua gracilis - Carex filifolia (needle-and-thread - blue grama grassthreadleaved sedge) association.

\section{Key Environmental Factors}

Along with effective fire suppression, the major driving force structuring plant communities is climatic variation, particularly "drought cycles", and herbivory.

\section{Biodiversity Significance}

No sensitive plant species were located.

\section{Land Use}

The bottomlands along the lower and uppermost stretches of Frenchman Creek are predominantly 
privately held and currently being used for hay production or intensive livestock grazing; the condition of the middle stretch is unknown at this time. The mostly erosive breaklands do receive livestock use but at a reduced level owing to the distance from water. The degree of uplands use is highly variable depending upon ownership, the management of particular pastures and water development. Grazing pressure from domestic ungulates is concentrated at certain points in the landscape (e.g. water sources, stock tanks, swales productive in graminoid biomass, etc.).

\section{Exotics}

Scattered populations of Cirsium arvense (Canada thistle), Conyza canadensis (horseweed) and Euphorbia esula (leafy spurge) were noted in the bottomlands of Frenchman Creek; these populations were on private lands, observed from a distance using binoculars. These same bottomlands have been plowed (we assume) and pasture grasses Bromus inermis (smooth brome), Poa pratensis (Kentucky bluegrass), etc. have been planted. Bromus japonicus (Japanese brome) occurs very scattered in the mixed-grass prairie; why it has not increased to troublesome proportions as it has in southeastern Montana and other states is unknown, but we speculate a change in the fire-return interval may be part of the explanation.

\section{Information Needs}

All components (breaklands, bottomlands, rolling prairie) of this landscape have been incompletely inventoried, owing in part to the remoteness of terrain and difficult access. The condition and composition of bottomland communities and composition of uplands in the vicinity of Woody Draw should be targets of any future inventory. From examining aerial photos and topographic maps we speculate that a number of shrubland community types (possibly dominated by Prunus virginiana (common chokecherry) and Shepherdia argentea (thorny buffaloberry)) have been overlooked.

The presence of the provisionally recognized communities of Rhus trilobata / Elymus lanceolatus, Juniperus horizontalis / Elymus lanceolatus, Juniperus horizontalis / Elymus trachycaulus, and Elymus lanceolatus - Elymus trachycaulus argues for a further inventory of this landscape (and those adjoining) to more fully authenticate these provisional types.

\section{Management Needs}

The noxious weed problem is apparently minor at present. Euphorbia esula (leafy sprurge) has been documented in the vicinity of riparian zones and poses the most serious threat. A more complete inventory of bottomlands would most likely reveal new Euphorbia esula populations. These populations should be eradicated or controlled with a weed management program. 


\section{ROCK CREEK CANYON LANDSCAPE}

\section{Directions}

Note: Portions of this site are located on private land and landowner permission is required to access these areas. Rock Creek Canyon is located about 35 air-miles northwest of Glasgow, MT. From Hinsdale on U.S. Route 2 take Valley County Road 537 (Hinsdale North Road) north for 17.2 miles. Exit to a dirt road bearing northeast and bear left at the first and second forks in the road and travel 1.7 miles, which places one in the Papoose Hills on State Lands (just past U.S.G.S marker on the boundary). Walking due east, one comes to the head of Bog Coulee, one of the easier coulees to navigate to the bottom of the Rock Creek canyon.

\section{Description}

The upland portion of this setting is typical of the northern glaciated plains with the distinction of having coarser-textured soils (loamy sands, sandy loams and fine sands), on which Pascopyrum smithii - Hesperostipa comata (thick-spike wheatgrass - needle-and-thread grass) and Hesperostipa comata Bouteloua gracilis - Carex filifolia (needle-and-thread - blue grama - threadleaved sedge grass) constitute the matrix communities. Scattered small patches of Calamovilfa longifolia - Hesperostipa comata (prairie sandreed) occur in the midst of mosaic communities often with no discernable change in the substrate (i.e. coarser-textured soils). Where Rock Creek and tributaries have downcut through sedimentary strata very contrasting slope exposures and positions are found. The more protected and mesic slopes exhibit small- to mid-sized patches of Juniperus scopulorum / Piptatherum micrantha (Rocky Mountain juniper / little-seed ricegrass) with a comparatively dense tree canopy and occasionally thick moss undergrowth. The south facing warmer exposures support highly variable, sparse vegetation on actively eroding slopes. These slopes often exhibit Pascopyrum smithii, Elymus lanceolatus and/or Juniperus horizontalis (creeping juniper) as the most ubiquitous species but having low overall canopy cover with just a few rhizomes traversing a very open slope. Where outcrops of bentonite or acid shale surface, communities of Artemisia longifolia (longleaf sagewort) and Eriogonum pauciflorum - Gutierrezia sarothrae (few-flowered wild buckwheat - broom snakeweed) are found. Riparian communities strung along perennial Rock Creek include wet meadow settings with Juncus balticus (Baltic rush), Carex praegracilis (clustered field sedge) and Deschampsia caespitosa (tufted hairgrass); Eleocharis palustris (common spikerush) in drawdown zones; Typha latifolia (common cattail) and Schoenoplectus acutus (hardstem bulrush) in marshlands with standing water most of the growing season. Stream terraces have Populus deltoides (plains cottonwood)-dominated woodlands with highly modified pasture grasses understories.

\section{Key Environmental Factors}

The focus of this site is Rock Creek Canyon and its steep exposures created by the downcutting of Rock Creek through soft and erosive sedimentary strata. This landscape has particularly extensive exposures of sandstone compared to much of the rest of Valley and northeastern Phillips Counties. Rock Creek is also a focus because it is one of the few perennial streams coursing through a largely intact prairie setting, where the only disturbance has been livestock grazing.

\section{Biodiversity Significance}

This site supports a diverse amphibian assemblage; three records of Bufo cognatus (Great Plains toad), and one record each of Rana pipiens (northern leopard frog) and Spea bombifrons (Plains spadefoot) were recorded from the Rock Creek landscape. In addition, this site supports a diverse avifauna with three grassland species recognized as priority I by Montana Partners in Flight (PIF); these include Ammodramus bairdii, (Baird's sparrow), Anthus spragueii, (sprague's pipit), and Centrocercus 
urophasianus (greater sage-grouse).

\section{Other Values}

Pools along Rock Creek provide a crucial water source for a variety of wildlife species. Structural diversity encompassed by the riparian setting is also an important wildlife draw.

\section{Land Use}

Obviously some of the Bankhead-Jones lands within this landscape were tilled quite some time ago. Though only cursorily inventoried, these lands for the most part appear to have undergone secondary succession with the furrows mostly having been obliterated through sheet and rill erosion, coming back to native species for the most part. Those areas that were once plowed and have since been grazed appear as a short grass prairie; most of these areas support poor quality Hesperostipa comata Bouteloua gracilis (needle-and-thread - blue grama) with scant Hesperostipa comata, often having a mat of Selaginella densa (compact spikemoss). The potential for wheatgrass species is expressed as scattered plants at best. Old livestock trails are located along ravine slopes where animals attempted to gain access to the waters of Rock Creek.

\section{Exotics}

Patches of Bromus inermis (smooth brome) and a few Agropyron cristatum (crested wheatgrass) plantings were noted. The condition of bottomlands and coulees is degraded with Euphorbia esula (leafy spurge) virtually rampant in some streamside locations and especially in a couple of Populus deltoides (plains cottonwood) stands. In these situations, the native undergrowth has been nearly completely competitively eliminated. Minor populations of Cirsium arvense (Canada thistle) were noted in a few swales on the Rock Creek floodplain.

\section{Information Needs}

The inventory of various side coulees feeding Rock Creek Canyon was incomplete; especially cursory was the assessment of the diversity of plant communities along the creek's riparian corridor and the degree of infestation by weedy species. The degree to which water-borne disseminules contribute to the weed population should be examined, because it is in the riparian corridor that infestations appear most severe.

\section{Management Needs}

Noxious weeds constitute a major threat to this landscape, especially the riparian corridor; a weed management plan needs to be formulated and instituted. 


\section{SOUTH FORK ROCK CREEK LANDSCAPE}

\section{Directions}

This site is found in the northernmost portion of Valley County between the Opheim Hills and the main branch of Rock Creek and encompasses approximately 43,917 acres. It is easily reached by taking State Route 24 from Glasgow to Opheim and then bearing due west, approximately 12 miles on the only county road originating on the west side of Opheim. This county road continues on to traverse the center of the eastern two thirds of the area. The road forks in Section 5 (of T 36 N, R 37 E) with branches accessing Lighthouse Hill and the northern reaches of Rock Creek.

\section{Description}

This landscape is typical of northern glaciated plains with gently rolling uplands, streams shallowly incised, and a thin layer of glacial till/drift mantling the ground. Pascopyrum smithii (western wheatgrass) communities dominate the landscape with either Hesperostipa comata (needle-and-thread) or Bouteloua gracilis (western blue grama). Elymus lanceolatus - Hesperostipa comata (thickspike wheatgrass - needle-and-thread) are found to a much lesser extent. These communities constitute the matrix vegetation. In most reaches of the South Fork Rock Creek the riparian zone is closely confined to the stream's bank and narrow floodplain. Several vegetation types are associated with the seasonally or temporarily high water tables within the floodplain; most are dominated by Pascopyrum smithii with either Poa secunda (Sandberg's bluegrass), Carex duriusculaa (threadleaf sedge), Distichlis spicata (inland saltgrass), or Eleocharis spp. (spikerush) present. Artemisia cana (silver sagebrush), though not often dense enough to constitute a shrubland, forms a discontinuous band along the floodplain interrupted or interspersed with small patches of Symphoricarpos occidentalis (western snowberry) and Salix exigua (coyote willow). A number of bentonite exposures occur in this landscape and are sparsely vegetated by Atriplex gardneri - Atriplex suckleyi (Gardner's saltsage - rillscale), which is easily spotted in spring by the subtle reddish flush of rillscale.

\section{Key Environmental Factors}

By far the major portion of this landscape is Bankhead-Jones land, which implies at least a portion was plowed at one time. However, apparently cropping did not succeed in this landscape, though, dryland agriculture is thriving to the east. This probably reflects that the South Fork Rock Creek Landscape occurrs on predomiantly Aridisols whereas the farmed acreage occupies the more productive Mollisols. Depending on how long the land was left fallow, secondary succession has occurred and resulting communities are in various states of succession. Considerable acreage has been planted to Agropyron cristatum (crested wheatgrass) to stabilize the soils. Prior to settlement this landscape had supported Bison bison (buffalo) as the primary grazers. Following the abandonment of the land, cattle have become the primary grazers and their grazing behavior and impact is significantly different from that of buffalo.

\section{Land Use}

Current land use is primarily cattle ranching.

\section{Exotics}

Agropyron cristatum (crested wheatgrass) was extensively planted in the late 20's and 30 's and flourishes to this day. This would be a good site to document the rate of invasion of natives into crested wheatgrass plantings but unfortunately the original vegetation composition of these planting sites can only be a matter of speculation. Agropyron repens (quackgrass) is sporadically distributed in the riparian zone of Rock Creek and several tributaries. 


\section{Information Needs}

Portions of this area were not inventoried, especially the riparian corridor of South Fork Rock Creek. The flats and very gentle slope supporting a provisional type termed Pascopyrum smithii - Poa secunda should be revisited over several seasons to document response to variation in precipitation and the nature of the soils, particularly the depth to a restrictive layer. It may also be possible to trace plant succession from farm abandonment to the current vegetation using fenceline contrasts. However, land use in the intervening years may be largely unknown. 


\section{Appendix C: Plant Community Descriptions}

This appendix includes plant community descriptions presented in alphabetical order. These descriptions exhibit varying degrees of development, from complete to a summary only. The most complete descriptions are generally taken from the International Classification of Ecological Communities (NatureServe, 2001) maintained by NatureServe and updated by state Natural Heritage programs. A few plant associations, identified with the prefix CEGLMTHP are recently nominated by the Montana Natural Heritage Program but have not yet received regional recognition and are not yet included in the National Classification: it is our intent to nominate these associations to the western regional clearinghouse for formal recognition. Others are provisional, meaning they await further documentation before being submitted into the National Classification. We have described nominated and provisional types from both literature sources and Montana-specific data. Cross-walking with neighboring states is incomplete, thus fields like "Range" and "States" are not included in the descriptions.

Artemisia cana / Elymus lanceolatus (Nassella viridula) Shrub Herbaceous ......................................... 1

Artemisia cana / Hesperostipa comata Shrub Herbaceous Vegetation ................................................... 1

Artemisia cana / Pascopyrum smithii Shrubland ........................................................................... 3

Artemisia tridentata ssp. wyomingensis / Pascopyrum smithii Shrub Herbaceous Vegetation ................. 4

Atriplex gardneri / Endolepis dioica Dwarf-shrubland ....................................................................... 5

Calamovilfa longifolia - Carex inops ssp. heliophila Herbaceous Vegetation ....................................... 6

Calamovilfa longifolia - Hesperostipa comata Herbaceous Vegetation ................................................ 7

Carex pellita - Calamagrostis stricta Herbaceous Vegetation .............................................................. 8

Elymus lanceolatus - Hesperostipa comata Northern Great Plains Herbaceous Vegetation .................... 9

Elymus lanceolatus - (Koeleria macrantha) Herbaceous Vegetation .................................................. 11

Elymus lanceolatus - Elymus trachycaulus Herbaceous Vegetation ................................................... 12

Elymus lanceolatus - Nassella viridula Herbaceous Vegetation .................................................... 13

Eriogonum pauciflorum - Gutierrezia sarothrae Badlands Sparse Vegetation ..................................... 15

Hesperostipa curtiseta - (Elymus lanceolatus) Herbaceous Vegetation ............................................. 16

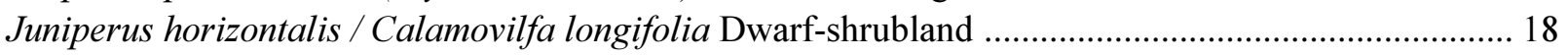

Juniperus horizontalis / Elymus lanceolatus Dwarf-shrubland ......................................................... 19

Juniperus horizontalis / Elymus trachycaulus Dwarf-shrubland ...................................................... 20

Juniperus horizontalis / Juncus balticus Dwarf-shrubland ........................................................... 21

Juniperus horizontalis / Schizachyrium scoparium Dwarf-shrubland .............................................. 22

Juniperus horizontalis / Hesperostipa curtiseta - (Elymus lanceolatus) Dwarf-shrubland ................... 24

Juniperus scopulorum / Piptatherum micranthum Woodland .............................................................. 24

Muhlenbergia cuspidata - Bouteloua gracilis Herbaceous Vegetation .................................................. 26

Pascopyrum smithii - Bouteloua gracilis Northern Plains Herbaceous Vegetation .............................. 27

Pascopyrum smithii - (Carex duriuscula) Herbaceous Vegetation ..................................................... 28

Pascopyrum smithii - Distichlis spicata Herbaceous Vegetation ......................................................... 29

Pascopyrum smithii - Eleocharis spp. Herbaceous Vegetation ............................................................ 29

Pascopyrum smithii - Nassella viridula Herbaceous Vegetation ........................................................ 31

Populus deltoides / Symphoricarpos occidentalis Woodland ............................................................. 32

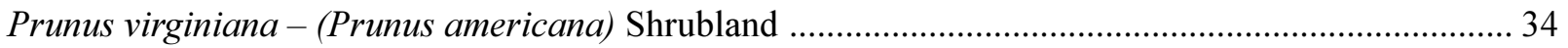

Rhus trilobata / Elymus lanceolatus - Nassella viridula Shrub Herbaceous ......................................... 35

Rhus trilobata / Schizachyrium scoparium Shrub Herbaceous Vegetation ............................................ 36

Spartina pectinata Western Herbaceous Vegetation ........................................................................ 37

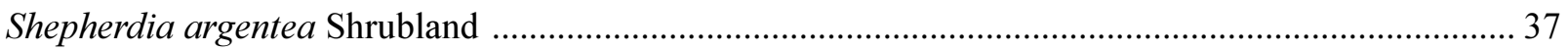

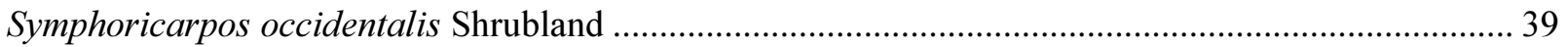


Artemisia cana / Elymus lanceolatus (Nassella viridula) Shrub Herbaceous

Silver Sagebrush / Thickspike Wheatgrass - (Green Needlegrass) Shrub Herbaceous

Global Rank: G2G3? State Rank: S2S3?

Element Code: CEGLMTHP48

\section{Element Concept}

Summary: This association has not been previously described however it appears to be common in northern Valley and Phillips Counties of Montana. It found on alluvial deposits on floodplains, terraces or benches, and alluvial fans. The soils are deep to moderately deep, largely without horizonation and primarily silt, sand or clay loams. The shrub component is dominated by Artemisia cana (silver sagebrush) but cover seldom is seen to exceed 20\% (hence the "shrub herbaceous" designation"; Symphoricarpos occidentalis (western snowberry), Chrysothamnus nauseosus (common rabbitbrush) and Rosa spp. (rose) occur scattered. Elymus lanceolatus (western wheatgrass) is both dominant and diagnostic with coverage of up to $70 \%$. Nassella viridula (green needlegrass) is usually present and well represented, depending on livestock impacts; other mesic graminoids regularly present include Elymus trachycaulus (bearded wheatgrass) and Carex duriuscula (needleleaf sedge). Achillea millefolium (common yarrow) and the introduced Melilotus officinalis (yellow sweetclover) are the only forbs consistently present.

Classification Comments: This association is currently based on limited sampling. This association shares many of the same features, both biotic and landscape settings, with Artemisia cana / Pascopyrum smithii (silver sagebrush / western wheatgrass). With further sampling the two types might be found to diverge in their soil parameters but currently we view them as ecological analogues with Artemisia cana / Elymus lanceolatus (Nassella viridula) occurring at the northern extreme of Montana whereas Artemisia cana / Pascopyrum smithii is more broadly distributed to the south and east (North Dakota, South Dakota, Wyoming). Within the Bitter Frenchman Creek study area the distributions of the two types is completely overlapping.

\section{Element Sources}

Authors: Cooper, S. V. \& C. Jean, MTNHP Confidence: 3

References: Cooper et al. 2001

Artemisia cana / Hesperostipa comata Shrub Herbaceous Vegetation

Silver Sagebrush / Needle-and-Thread Shrub Herbaceous Vegetation

Global Rank: G3 State Rank: S3

Element Code : CEGL001553

\section{Element Concept}

Summary: This prairie association, which generally occurs in small patches (less than one hectare), occurs in the northwestern Great Plains. In Montana, it is found on benches to gently inclined slopes (30\% maximum recorded) in the vicinity of breaklands. Similar habitats (old river terraces, badlands, ravine sideslopes and valley walls) support its occurrence in Alberta. Sites occur on various parent materials, but mostly well-drained, often sandy, glacial drift and sandy alluvium. Artemisia cana is decidedly the dominant shrub with canopy coverage to $50 \%$, but averaging around $25 \%$, which places it on the cusp of being a true shrub type. Artemisia frigida is the only shrub/subshrub with greater than $50 \%$ constancy and its cover seldom exceeds $3 \%$. A number of graminoids have high constancy 
including Bouteloua gracilis, Carex filifolia, Koeleria macrantha, and Poa secunda (= Poa sandbergii), but only Hesperostipa comata exhibits both $100 \%$ constancy and the highest cover values (averaging 38\%). Forbs constitute an insignificant component, virtually none occurring in greater than trace amounts. Those exceeding 50\% constancy are Sphaeralcea coccinea, Pediomelum argophyllum (= Pediomelum argophyllum), and Gaura coccinea. This association is hypothesized to represent the driest environment capable of supporting Artemisia cana. Occasional fire probably has reduced Artemisia spp. cover and density to low levels and maintains the shrub herbaceous community structure.

Environment: It is found on benches to gently inclined slopes (30\% maximum recorded value) of rolling prairie, steeper ravine slopes, and all manner of topography in the vicinity of breaklands. It occurs on various parent materials but mostly well-drained, often sandy, glacial drift. The ground cover is highly variable with some sites (putatively overgrazed) having a sward of Selaginella densa and lichens, while others have $70 \%$ litter and trace amounts of Selaginella densa; only one plot had as much as 10\% exposed soil, gravel and rock (combined cover).

Vegetation: Artemisia cana (probably Artemisia cana ssp. cana [Shultz 1984]) is decidedly the dominant shrub with canopy coverage ranging to $50 \%$ on heavily grazed sites, but averaging $27 \%$; Artemisia frigida is the only shrub/subshrub with greater than $50 \%$ constancy and its cover did not exceed 3\%. A number of graminoids have high constancy, Bouteloua gracilis, Carex filifolia, Koeleria macrantha, and Poa secunda (= Poa sandbergii), but only Hesperostipa comata exhibits both $100 \%$ constancy and the highest cover values (averaging 38\%). Muhlenbergia cuspidata and Calamovilfa longifolia had inexplicably high cover on some sites. Forbs constitute an insignificant component, occurring in trace amounts; those exceeding 50\% constancy are Sphaeralcea coccinea, Pediomelum argophyllum (= Pediomelum argophyllum) and Gaura coccinea. This association is hypothesized to represent the driest environment capable of supporting Artemisia cana; most often this association grades to upland range sites dominated by Hesperostipa comata and Bouteloua gracilis and to the Artemisia cana / Pascopyrum smithii association that occupies more mesic positions on lower floodplain terraces.

Comments: In the Bitter Creek / Frenchman Creek study area this is a very minor type probably owing to the relative paucity of coarse-textured substrates (sandstone derived); this association was not found on fissile shales that weather to coarse textures and in some ways mimic sandstone derived soils.

In their vegetation key to this type DeVelice et al. (1995) allow for the occasional dominance of Bouteloua gracilis and/or Calamovilfa longifolia, in lieu of Hesperostipa comata (which is by far the usual case), to be indicative of the association. The cover of Artemisia cana ranges widely, spanning the values defining shrub herbaceous and shrubland categories. The type is described as shrub herbaceous because the preponderance of stands had cover of less than $25 \%$, though the average cover just exceeded this value. This type could probably be combined with Artemisia cana / Calamovilfa longifolia Shrub Herbaceous Vegetation (CEGL001555) without compromising the ecological information embedded in either type. Within Artemisia cana / Pascopyrum smithii Shrub Herbaceous Vegetation (CEGL001556) rhizomatous wheatgrasses and/or Nassella viridula are dominant or of sufficient cover to indicate a moister habitat than Artemisia cana / Hesperostipa comata Shrub Herbaceous Vegetation (CEGL001553). In Wyoming's Cheyenne River Basin, stands of Artemisia cana / Bouteloua gracilis - Calamovilfa longifolia Shrub Herbaceous Vegetation (not in USNVC) (renamed Artemisia cana ssp. cana / Calamovilfa longifolia association by Thilenius et al. (1995), G. P. Jones pers. comm.) occur on well-drained sand dunes and lack, or have low coverage of, Pascopyrum smithii, but support Hesperostipa comata as 100\% constant; Hesperostipa comata coverages approach those of the named diagnostic grasses. At least two plots of the Artemisia cana / Hesperostipa comata Shrub Herbaceous Vegetation (CEGL001553) having Calamovilfa longifolia dominant, could be allocated to Artemisia cana ssp. cana / Calamovilfa longifolia Shrub Herbaceous Vegetation (CEGL001555). 
Grank \& Reasons: G3 (99-12-06).

This small patch type currently has a circumscribed geographic distribution, though its description from Saskatchewan and North Dakota would not be unexpected. Habitats with the potential to support this type appear to be relatively abundant, but the type itself is comparatively uncommon. This type's affinity for well-drained benches and gently inclined landforms in a primarily agricultural landscape puts it at a moderate risk for agriculture conversion. Fortunately, this landform also occurs in breakland and badland environments less desirable for agriculture, thus lessening the chances of this uncommon type being converted to agriculture. Its graminoid composition renders it only moderately attractive to cattle, and the scarcity of forbs decrease its value as sheep range.

\section{Element Distribution}

Range: This association is well documented from Montana and Alberta, Canada. The same or a closely analogous type occurs in Wyoming, and some permutation of the type is to be expected in northwestern North Dakota and Saskatchewan.

\section{Element Sources}

Authors: S.V. Cooper and C. Jean, WCS Confidence: 1

References: DeVelice et al. 1991, DeVelice et al. 1995, Thilenius et al. 1995

Artemisia cana / Pascopyrum smithii Shrubland

Silver Sagebrush - Western Wheatgrass Shrubland

Global rank: G4

State rank: S4

Element Code: CEGL001072

\section{Element Concept}

Summary: The silver sagebrush - western wheatgrass shrubland is found mainly in the western Great Plains on flat alluvial deposits on floodplains, terraces or benches, and alluvial fans. The soils are moderately deep to deep and either silt loam, clay loam, or sandy loam. Flooding may occur periodically and this tends to retard soil development. This community is dominated by a combination of shrubs and graminoids. The total vegetation cover is moderate. The tallest and most conspicuous stratum in this community is a shrub layer that is usually $0.6-1.2 \mathrm{~m}$. dominated by Artemisia cana. Grass cover is dominated by Pascopyrum smithii and typical forbs of this community are Achillea millefolium (yarrow) Gaura coccinea (scarlet gaura), Sphaeralcea coccinea (red globe-mallow), and Lactuca pulchella (blue lettuce). This plant association is uncommon in glaciated landscapes, though it was noted to be scattered along most major drainages within the study area, fairly confined to streambanks and their immediate vicinity. Cattle heavily utilize these bottomlands and often the Pascopyrum smithii is heavily grazed; in these conditions Iva axillaris (poverty-weed) and Plantago patagonica (indian-wheat) appear to be the increaser species. While this plant association is not restricted to riparian settings, those observed fit the wetland characterization for it as presented in Hansen et al. (1995). In the BCFC study area Artemisia cana canopy cover was usually considerably less than $25 \%$, which would qualify stands as shrub herbaceous vegetation (NVC Standards).

\section{Element Distribution}

Range: This silver or coaltown sagebrush shrubland is found in the northwestern Great Plains and Rocky Mountains of the western United States, ranging from Montana and North Dakota, south to 
Nebraska.

States/Provinces: MT:S4, ND:S2S3?, NE:S?, SD:SU

\section{Element Sources}

Authors: Drake, J. F., WCS mod. S.V. Cooper and C. Jean, MTNHP Confidence: 1

References: Hansen et al. 1984, Hansen et al. 1991, Hansen et al. 1995, Hanson and Whitman 1938, Hirsch 1985, Johnston 1987, Nelson 1961, Steinauer and Rolfsmeier 1997, U.S. Forest Service (USFS) 1992

Artemisia tridentata ssp. wyomingensis / Pascopyrum smithii Shrub Herbaceous Vegetation Wyoming Big Sagebrush / Western Wheatgrass Shrub Herbaceous Vegetation

Global Rank: G4 State Rank: S?

Element Code: CEGL001044

\section{Element Concept}

Environment: Artemisia tridentata ssp. wyomingensis / Pascopyrum smithii an extensive plant association in the western portion of the Northwestern Glaciated Plains but its coverage drops dramatically to the east and in northern Valley and Phillips Counties where only widely scattered, generally less than 5 acre stands are present. This association is typically found on gently rolling (slope inclination $<10 \%$ ), till-mantled surfaces; it is also found in breaklands and on well-drained alluvial terraces. Others (Hansen and Hoffman 1988, Hansen et al. 1984, Tisdale and Hironaka 1981, Jorgensen 1979, Mackie 1970) have described this type as an edaphic or topoedaphic climax, associated with heavy soils in southeastern MT or shallow, gravelly, or claypan surface soils in north-central MT. Lacking adequate soils information we can only speculate, based on landscape position, that most of our sites represent edaphically controlled conditions. The amount of exposed substrate is generally considerably higher (average $50 \%$, ranging to $80 \%$ ) than for adjacent communities.

Vegetation: This type is recognized (in part) by Artemisia tridentata spp. wyomingensis being well represented in the shrub layer, usually its cover does not exceed $50 \%$, averaging somewhere in the 20 $35 \%$ range. There are no other shrubs with high constancy but Chrysothamnus nauseosus, Artemisia frigida and Gutierrezia sarothrae are regularly present with low coverages. Well-represented Elymus lanceolatus is diagnostic for the herbaceous layer, though intensively grazed areas may have lower coverages (average cover approximately 20\%). Ease of livestock access makes these sites prone to overgrazing; none of the sampled sites were even close to pristine. Even in livestock exclosures weedy or invader species (e.g. Melilotus officinalis, Taraxacum officinalis, Bromus tectorum) are aggressively expanding (having gained a foothold prior to exclosure creation). Somewhat inexplicably Selaginella densa (compact clubmoss) does not seem to increase on these sites the way it does on grassland sites, but it can occur with high cover values under unexplained circumstances.

Graminoids with moderate to high constancy are Nassella viridula, Koeleria macrantha, Poa secunda, Carex filifolia (or Carex duriuscula) and Pseudoroegneria spicata. Of these, only Nassella viridula and Pseudoroegneria spicata were noted to be occasional layer co-dominants or present with greater than $10 \%$ cover, but never the two in the same stand. Hesperostipa comata was well represented on sandier sites (sandy loams). Forbs are a minor component; those occurring with greater than $50 \%$ constancy are Sphaeralcea coccinea and Vicia americana.

Comments: This association is apparently at its northern limits in Valley and Phillips Counties. This association is reported as extensive in Wyoming and present in Colorado. However, between the 
southern portion Petroleum, Fergus and Garfield Counties and the above cited states the great majority of the landscape is apparently occupied by Artemisia tridentata ssp. wyomingensis / Pascopyrum smithii. The Artemisia tridentata ssp. wyomingensis / Pascopyrum smithii type is distributed from central MT (Jorgensen 1979, Mackie 1971) east to southeastern MT and contiguous portions of North and South Dakota (Hansen and Hoffman 1988, Hansen et al. 1984) and south to Wyoming, Utah and Colorado. The answer as to why there should be a huge gap in its distribution between central Montana and Wyoming might be answered by critically distinguishing Elymus lanceolatus from Pascopyrum smithii. Neither association is present in far northeastern MT, nor reported for the Canadian prairies.

\section{Element Sources}

Authors: WCS, mod. S.V. Cooper and C. Jean, MTNHP Confidence: 2

References: Cooper et al. 2001, Giese 1975, Gross 1955, Leucite Hills Mine Application n.d., Lundberg 1977, Marr et al. 1979, Steger 1970, Terwilliger et al. 1979a

Atriplex gardneri / Endolepis dioica Dwarf-shrubland

(Gardner's Saltsage / Rillscale)

Global Rank: G? State Rank: S2?

Element Code: CEGLMTHP49

\section{Element Concept}

Summary: The Gardner's saltsage / rillscale association is broadly distributed across northern Valley County and abundantly represented in the Bitter Creek Badlands, associated primarily with bentonite deposits but also occurring on heavy soils, clay and silty clays, derived from shales or mudstone. Initial impressions are that factors such as slopes steepness and aspect govern the density/cover of dominant species but not their presence or absence. Soils have low infiltration rates and show the effects of sheet and rill erosion; the surfaces are often mantled with gravels weathered old shores or streambeds as well as salt deposits with the amount of exposed surface in excess of $95 \%$. The vegetative expression is highly variable by year and season due to the diagnostic species, Endolepis dioica (rillscale) an annual forb, responding to the vagaries of precipitation and summer drought; coverages may be as high as $40 \%$ one year and barely perceptible the next. Atriplex gardneri cover is highly variable by site, from 5 $\%$ in the most depauperate cases, to over $20 \%$ on sites with slightly more favorable soils. The shrub Sarcobatus vermiculatus (black greasewood) and subshrubs Gutierrezia sarothrae (broom snakeweed) and Eriogonum pauciflorum (fewflower buckwheat) are consistently present in trace amounts. Grass and forb cover and diversity is exceedingly low with only Elymus lanceolatus (thickspike wheatgrass) and Achnatherum hymenoides (indian ricegrass) occurring with regularity.

Comments: A number of Atriplex gardneri-dominated plant associations have been described for Montana, Wyoming, Colorado, and Utah. Three of the associations occurring in Montana (Atriplex gardneri / Achnatherum hymenoides, Atriplex gardneri / Monolepsis nuttalliana, Atriplex gardneri / Eriogonum pauciflorum) are structurally similar to Atriplex gardneri / Endolepis dioica; they are also notably depauperate in cover (approach being technically "sparse") and species, have considerable compositional overlap among types and occur under similar environmental conditions, including ostensibly substrate type. We hypothesize that subtle distinctions in substrate (soils) hold the key to understanding the differences among these types. Such stark sites generate little curiosity as to controlling variables, however, they have piqued the interest of wildlife biologists, who speculate as to their appropriateness as mountain plover habitat. 


\title{
Element Sources
}

\author{
Authors: Cooper, S. V. \& C. Jean, MTNHP Confidence: 3
}

References: Cooper et al. 2001

Calamovilfa longifolia - Carex inops ssp. heliophila Herbaceous Vegetation

Prairie Sandreed - Sun Sedge Herbaceous Vegetation

Global Rank: G3? State Rank: S3

Element Code: CEGL001471

\section{Element Concept}

Summary: The prairie sandreed - sun sedge association occurs in the northern Great Plains states and probably extends well into Canada's plains provinces (Coupland 1992). Stands occur on substrates with a significant component of sand, sandy loams or just sands, of colluvial or aeolian origin. This community tends to occur as small to large patches in gently rolling terrain. Calamovilfa longifolia dominates a tall and open canopy with scattered mid-grasses and a highly discontinuous to sometimes a thick mat of the short-graminoid and other diagnostic species, Carex filifolia (threadleaf sedge). Other graminoids commonly present include Bouteloua gracilis (blue grama), Koeleria macrantha (prairie junegrass), Muhlenbergia cuspidata (plains muhly) and Hesperostipa comata (needle-and-thread). Pediomelum argophyllum (silver-leaved scurf-pea) and Dalea purpurea (purple prairie-clover) are the commonest forbs, though their canopy cover tends to not much exceed trace amounts. The only shubs consistently present include Artemisia frigida (fringed sage) and Rosa arkansana (prairie rose), though their canopy cover seldom exceeds 5\%. As with other sandy-soil communities Selaginella densa (dense clubmoss) is sporadically present and expresses a fraction of the cover (usually less than 5\%) that it exhibits on finer-textured soils.

Environment: Stands are found on gently rolling uplands with little to moderate slopes (typically between 0 and 20\%, but occasionally as high as 39\%) (Hirsch 1985, Hansen and Hoffman 1988). The soils are sand, sandy loam, or loamy sand and there is rarely substantial soil horizon development (Hanson and Whitman 1938). The parent material is sandstone (USFS 1992). Moisture levels may be high deep in the profile.

Vegetation: The vegetation structure is somewhat open, with cover averaging $65 \%$ in parts of its range (USFS 1992). The vegetation is dominated by graminoids, with two strata, one of mid to tall grasses, the other of dense short sedges. In the taller grass layer, the most abundant species is Calamovilfa longifolia. Other species found in this layer include Koeleria macrantha, Schizachyrium scoparium, and Hesperostipa comata (= Stipa comata). Pascopyrum smithii may be present on some stands with finer soil textures. The short-graminoid layer is composed chiefly of Carex filifolia and Carex inops ssp. heliophila, which may have high cover values. Other upland Carices, such as Carex duriuscula (= Carex eleocharis), as well as Bouteloua gracilis and Muhlenbergia pungens, may also be present. Forb species diversity is moderate, but they do not contribute greatly to the cover (Hanson and Whitman 1938, USFS 1992). The forbs that are typical of this community include $\sim$ Artemisia dracunculus, Artemisia frigida (considered a shrub by some authors), Artemisia ludoviciana, Chenopodium album, Chenopodium leptophyllum, Lathyrus spp., Liatris punctata, Lygodesmia juncea, Phlox hoodii, and Psoralidium lanceolatum. Shrubs are uncommon. When shrubs are present they are short shrubs such as Yucca glauca, Rosa spp., and Artemisia frigida. 


\section{Element Distribution}

States/Provinces: MT:S3?, ND:SU, SD:S?, SK:S?

Range: This prairie sandreed grassland is found in the northwestern Great Plains of the United States and Canada, ranging from the western Dakotas to Montana and Saskatchewan.

\section{Element Sources}

Authors: K. Hirsch; mod. J. Drake \& D. Faber-Langendoen, MWCS; S. V. Cooper\& C. Jean, MTNHP Confidence: 2

References: 1992Cooper et al. 2001, Hansen 1985, Hansen and Hoffman 1988, Hansen et al. 1984, Hanson and Whitman 1938

Calamovilfa longifolia - Hesperostipa comata Herbaceous Vegetation

Prairie Sandreed - Needle-and-thread Herbaceous Vegetation

Global Rank: G3 State Rank: S?

Element Code: CEGL001473

\section{Element Concept}

Summary: The prairie sandreed - needle-and-thread association occurs in most abundantly where sandy substrates obtain, the central Great Plains and specifically the Nebraska Sandhills, and becomes less extensive to the north. Stands occur on stabilized sand dunes, interdunal swales and on colluvial sands. Soils are medium to fine sands originating from eolian or colluvial processes. The vegetation has an open canopy, dominate by mid- to tall grasses. Calamovilfa longifolia is usually the conspicuous dominant, ranging from 30 to $90 \%$ canopy cover, with the shorter Hesperostipa comata somewhat obscured and usually exhibiting less cover (10 to 40\%). Accessory graminoids include the high constancy-low coverage Bouteloua gracilis (blue grama), Koeleria macrantha (prairie junegrass) and Carex filifolia (threadleaf sedge) and those with occasionally high cover values, such as Pascopyrum smithii (western wheatgrass), Calamagrostis montanensis (plains reedgrass), Achnatherum hymenoides (indian ricegrass) and Carex inops (sun sedge). Forb diversity and cover is low; Thermopsis rhombifolia (round-leaved thermopsis) is the only forb present whose constancy exceeds $50 \%$. Shrubs cover is also notably depauperate with only Yucca glauca (yucca), Rosa arkansana (prairie rose) and Rhus trilobata (skunkbush sumac) having slightly greater than trace amounts in less than half the examined occurrences. This is one of several upland communities in which Selaginella densa (dense clubmoss) is both uncommon and exhibits low canopy cover as well.

Environment: Stands occur on stabilized sand dunes, as well as in interdunal valleys or draws, colluvial sands, and, less commonly, silty terraces of intermittent streams. Soils are medium to fine sands formed either from eolian or colluvial processes. For example, in Nebraska stands occur below sandstone outcrops and escarpments. More rarely, stands occur on floodplain terraces of intermittent streams, where soils are moderately deep, poorly drained, silty loams and loams (Heerwagen 1958, USDI 1979, Barnes et al. 1984, Steinauer and Rolfsmeier 2000).

Vegetation: The vegetation has an open canopy, dominated by mid to tall grasses. Calamovilfa longifolia is the most conspicuous grass. Other common grasses include Bouteloua gracilis, Bouteloua gracilis, Koeleria macrantha, Achnatherum hymenoides (= Oryzopsis hymenoides), Sporobolus cryptandrus, and Hesperostipa comata (= Stipa comata). Pascopyrum smithii (= Agropyron smithii) and Nassella viridula (= Stipa viridula) may occur on more level sites at the base of slopes (Barnes et al. 1984, Steinauer and Rolfsmeier 2000). Andropogon hallii may also be present. Sedges are rare but 
could include Carex inops ssp. heliophila. Forb diversity ranges from low to moderate, depending on the site. Dry valley sand prairies may be particularly forb-rich. Silty terraces of intermittent streams may contain Artemisia frigida, Artemisia ludoviciana, Gutierrezia sarothrae, Psoralidium tenuiflorum, and Yucca glauca (Steinauer and Rolfsmeier 2000). Shrubs are scattered and infrequent to absent, with Rhus trilobata the most common species. These areas are highly susceptible to invasion by exotic brome grasses (Bromus japonicus, Bromus squarrosus, Bromus tectorum) and may be quite weedy (Heerwagen 1958, USDI 1979, Steinauer and Rolfsmeier 2000).

Study Area Comments: This is a highly restricted plant association within the study area, occurring as small patches on colluvial sands in the Rock Creek Canyon vicinity and a few isolated sandy outcrops in the Bitter Creek Badlands vicinity. With a greater degree of soil genesis on sandy loam it appears that Carex longifolia - Hesperostipa comata gives way to Pascopyrum smithii - Hesperostipa comata or Elymus lanceolatus - Hesperostipa comata. Also found for the study area is the Calamovilfa longifolia - Carex filifolia association that appears to occur on identical substrates with closely similar environmental conditions to those supporting Calamovilfa longifolia-Hesperostipa comata. In southwestern Montana, also on sandy substrates, is found the Calamovilfa longifolia-Carex inops association. What condition(s)/factor(s) might lead to these differential expressions on essentially analogous sites is currently unknown.

\section{Element Distribution}

Range: This prairie sandreed grassland community type occurs in the central and northern Great Plains region of the United States, ranging from Colorado and Nebraska, north to Wyoming and South Dakota.

States/Provinces: AB?, CO?, MT:S3, NE:S?, SD:S?, WY:S3

\section{Element Sources}

Authors: G. Steinauer and S. Rolfsmeier; mod. D. Faber-Langendoen, WCS; mod. S.V. Cooper \& C. Jean, MTNHP Confidence: 2

References: Bureau of Land Management 1974, CDM Consultants n.d., Johnston 1987, Mine Reclamation Consultants 1977

Carex pellita - Calamagrostis stricta Herbaceous Vegetation

Woolly Sedge - Narrow-spiked Reedgrass Herbaceous Vegetation

Global rank: G3? State rank: S?

Element Code: CEGL002254

\section{Element Concept}

Summary: This sedge-bluejoint wet meadow is found in the northern tallgrass prairie region and in the northeastern Great Plains. Stands occur on level ground in shallow depressions and other lowlands on poorly drained sandy, loamy, or silty clay soils. Standing water may be present for a few to several weeks during most years. Soil $\mathrm{pH}$ is circumneutral to somewhat alkaline and organic content can be moderately high. The vegetation of this community provides approximately $100 \%$ cover and the dominant vegetation is graminoids, typically $0.5-1.0 \mathrm{~m}$ tall. Forbs can be common, but shrubs are rarely found in this type. The most abundant species are Calamagrostis stricta, Carex pellita $(=$ Carex lanuginosa), Carex sartwellii, Anemone canadensis, Apocynum cannabinum, Symphyotrichum lanceolatum (= Aster lanceolatus), Eleocharis compressa, Juncus balticus, Phalaris arundinacea, Polygonum amphibium, and Schoenoplectus americanus (= Scirpus americanus). Carex buxbaumii may be common, except in North Dakota. 
Environment: This community occurs on level ground in shallow depressions and other lowlands on poorly drained sandy, loamy, or silty clay soils. Standing water can be present for a few to several weeks a year (Dix and Smeins 1967, Smeins and Olsen 1970). Soil pH is circumneutral to somewhat alkaline, and organic content can be moderately high.

Vegetation: The vegetation of this community provides approximately $100 \%$ cover and the dominant vegetation is graminoids, typically $0.5-1.0 \mathrm{~m}$ tall. Forbs can be common, but shrubs are rarely found in this type. The most abundant species are Calamagrostis stricta, Carex pellita (=Carex lanuginosa), Carex sartwellii, Anemone canadensis, Apocynum cannabinum, Symphyotrichum lanceolatum (= Aster lanceolatus), Eleocharis compressa, Juncus balticus, Phalaris arundinacea, Polygonum amphibium, and Schoenoplectus americanus (= Scirpus americanus). Carex buxbaumii may be common, except in North Dakota.

Study Area Comments: This plant association appears to be closely related to the plant associations dominated by clustered field sedge (Carex praegracilis) and awned sedge (Carex atherodes), at least as expressed in Valley and Sheridan Counties, Montana (Heidel et al. 2001). All three sedge species are found in relatively fresh, low alkalinity conditions. Carex pellita is characterized as a "wet meadow" species (Stewart and Kantrud 1972), but in the wet year of 1999, was noted in wetland basins of similar mid-season depth (app. 1. ft) as the seasonally inundated Carex atherodes wetlands. Calamagrostis stricta (narrow-spiked reedgrass) is a codominant with wooly sedge elsewhere in the range of this plant association, but within the study area Calamagrostis stricta was decided a subordinate species; in a few observations from Sheridan County Carex pellita alone was present with no representation of Calamagrostis stricta. Further sampling is needed to describe the plant association as represented in Montana.

\section{Element Distribution}

Range: This sedge-bluejoint wet meadow is found in the northern tallgrass prairie region and in the northeastern Great Plains, ranging from northern Iowa, western Minnesota, the Dakotas west to central Montana and parts of the Canadian prairie provinces.

States/Provinces: IA:SU, MB:SU, MN:S?, MT:S3?, ND:S?, SD:S?, SK:S?

\section{Element Sources}

Authors: J. Drake; mod. D. Faber-Langendoen, MCS; mod. S. V. Cooper and C. Jean, MTNHP Confidence: 3

References: Dix and Smeins 1967, Nelson et al. 1981, Smeins and Olsen 1970

Elymus lanceolatus - Hesperostipa comata Northern Great Plains Herbaceous Vegetation

Thickspike Wheatgrass - Needle-and-Thread Great Plains Herbaceous Vegetation

Global Rank: G3? State Rank: S3?

Element Code: CEGLMTHP43

\section{Element Concept}

Summary: This is a productive plant association, highly characteristic of the northern Great Plains provinces and areas of adjoining states having glaciated landscapes. It is found on well-drained slopes and gently rolling uplands with fine-textured to loamy soils. Heidel et al. (2000), have advanced this as a "new" association while acknowledging it has been previously sampled and described, but as part of other associations. They speculated it may have been a prevalent association in the northeastern corner 
of Montana and the collapsed moraine of Saskatchewan and North Dakota. It owes its scarcity to its inherent productivity, having been put into cereal grain production. Just as in Montana's Sheridan County landscape this is a major type in the Bitter Creek / Frenchman Creek landscape and may have had a vastly greater extent prior to settlement.

Environment: The typical setting for this association in the BCFC landscape is well-drained rolling uplands with fine-textured or loamy soils. It also occurs on gentle to moderate slopes, particularly those with warmer aspects. It may extend to toeslopes where it gives way to Elymus lanceolatus Nassella viridula, if sufficient moisture is present.

Vegetation: Graminoid canopy cover usually exceeds $80 \%$; of the two diagnostic species Elymus lanceolatus usually has the greater cover, except where grazing has been intensive. Though midgrasses are strongly dominant, short graminoids, including Carex filifolia (threadleaf sedge), Carex duriuscula (needleleaf sedge) and Bouteloua gracilis (blue grama), occur in more than trace amounts, especially with increased grazing pressure. Artemisia frigida (fringed sage), Gutierrezia sarothrae (broom snakeweed) and diminutive specimens of Artemisia cana (silver sagebrush) are consistently present, the first two increasing as grazing intensifies. Commonly associated forbs include Phlox hoodii (Hood's phlox), Sphaeralcea coccinea (scarlet globemallow), Vicia americana (American vetch), and Anemone patens (Pasque-flower).

\section{GRank \& Reasons: G3?}

We propose this as a new association; there is a rare plant association, (CEGL001746) from Oregon and Washington with the same Latin binomials. We distinguish (with the Northern Great Plains descriptor) the association described herein because it is geographically, ecologically and compositionally (at least in subordinate vegetation) dissimilar to the type of similar name identified from the Northwest.

Comments: The documentation of this type as widespread in northern Valley County and adjacent Phillips County considerably expands the area to which the following statement applies "this cool season, mid-grass plant association is distinguished by Elymus lanceolatus (thickspike wheatgrass) as co-dominant, replacing Pascopyrum smithii (western wheatgrass) as the most widespread wheatgrass in the northern Missouri Coteau of northwestern North Dakota and northeastern Montana" (Heidel et al. 2000).

\section{Element Distribution}

Range: This grassland type is described from the U. S. portion of northwestern Great Plains and with appropriate crosswalking will undoubtedly be demonstrated from the Canadian Prairie Provinces.

Nations: CA, US

States / Provinces: MT:S3?

\section{Element Sources}

Author(s): Heidel, B., S. V. Cooper and C. Jean, MTNHP Confidence: 2

References: Heidel et al. 2000, Cooper et al. 2001 
Elymus lanceolatus - (Koeleria macrantha) Herbaceous Vegetation

Thick-spike Wheatgrass - Prairie Junegrass Herbaceous Vegetation

Global rank: G? State rank: S?

Element Code (state provisional): CEGLMTHP39

\section{Element Concept}

Summary: Thick-spike wheatgrass - prairie junegrass herbaceous vegetation is a productive prairie plant association found in the northern Great Plains provinces and northernmost areas of adjoining states in glaciated landscapes on fine textured soils. It is prevailing vegetation on clay deposits occupying the beds of former glacial lakes in the provinces, and otherwise a mosaic component on the finelytextured clay loam and silt loam soils on outwash channels and till deposits in both states and provinces. It is presented in this study as a "new" plant association, though it has been previously sampled and described in related Canadian vegetation classification systems.

Environment: The typical environment for this plant association type has been characterized as lacustrine clay soils that were deposited as glacial lakebeds (Coupland 1950,1960). It was prevalent in this habitat but the landscape has been extensively broken in the Canadian Provinces, and is poorly represented further south in Montana, where at one representative glacial lakebed site it appears that Pascopyrum smithii (western wheatgrass) achieves dominance with Nassella viridula (green needlegrass) (Cooper and Heidel 1999).

The typical Canadian plains environment, where this type is remarked to be prevalent, provides a context for understanding its environment at the southern limits of its range. In the Missouri Coteau of Sheridan County, is widespread in mosaic and large patch patterns on collapsed moraine, where it is consistently present at high points on the landscape. It encompasses the near-level upland segments of the silty and clayey range sites. It is consistently found on Zahill series soils derived from clay loam glacial till; often in mosaic patterns combined with the Williams series on steeply rolling collapsed moraine simply mapped as Zahill-Williams complex, hilly, 15-25\% slope (Richardson and Hanson 1977). Despite the rolling nature of the landscape, this plant association is restricted to nearly level (0$5 \%$ ) upland hilltop positions where its extent is determined in large part by the degree that the landscape includes level terrain.

Vegetation: This plant association has a graminoid cover of $70-100 \%$ with Elymus lanceolatus (thickspike wheatgrass) constituting at least half of total cover and is sometimes the sole dominant. Koeleria macrantha (prairie Junegrass) is present and variously comprises less than $1 \%$ to almost half of total cover. This is a midgrass plant association that has a minor component of short graminoids, most often including sedges, Carex duriuscula (needleleaf sedge) and Carex filifolia (thread-leaved sedge) and traces of Bouteloua gracilis (blue grama). This grassland usually appears dense and homogeneous, occasionally interrupted by relatively sparse pockets of forbs in patches. The number of different forb species and their abundance tend to be very low. The most common and characteristic associated species include Linum lewisii (blue flax), Machaeranthera pinnatifida (spiny goldenweed), and Sphaeralcea coccinea (scarlet globe-mallow). Total forb canopy cover is generally less than 5\%.

This is one of the more species-poor upland associations in the study area, as indicated by mean number of species per vegetation sampling plot, yet it is also one of the most productive, and lends itself to both landscape structural heterogeneity and mosaic richness. Intact prairie pothole tracts may represent some of the best-developed and most extensive examples in Montana.

Study Area Comments: This is an uncommon type within the study area landscape. We postulate most of this highly productive type is under cultivation as it occupies habitat that is generally among 
the most readily plowed in the landscape and if encompassed in turnback lands is slow to achieve its prior composition. In Sheridan County, it is an integral part of the prairie pothole landscape mosaic and scattered widely across the rest of the county on top of gentle hills and ridges, as well as on benches and terraces of glacial meltwater valleys. It has been plowed as it occurred on level terrain elsewhere.

The two major species of wheatgrasses have the highest productivity among dominant mixed grass prairie species (Coupland 1950). Elymus lanceolatus (thick-spike wheatgrass) achieves much higher density and canopy cover than Pascopyrum smithii (western wheatgrass) (Heidel pers. obs). Clipping studies have documented that the "wheatgrass-junegrass faciation" has the highest forage yield (tons acre) in the mixed grass prairie landscape (Coupland 1950). Where Elymus lanceolatus - (Koeleria macrantha) Herbaceous Vegetation makes up more than a trace of primary range, the task of maintaining or restoring its condition is important in planning livestock use while maintaining cover, productivity, and landscape diversity. This community is subject to heavy litter build-up and declines in forb numbers under idle conditions.

Comments: Elymus lanceolatus - (Koeleria macrantha) Herbaceous Vegetation corresponds with the "Agropyron-Koeleria Faciation" of the "Mixed Prairie Association" documented by Coupland (1950, 1960). The prevalence of Elymus lanceolatus over all other species may be basis for naming the association based on this species alone, but it is more widely known by the corresponding Coupland name. Koeleria macrantha is said to achieve its highest cover values in this type (Coupland 1950). If Koeleria macrantha is not consistently present, it should be noted parenthetically in the plant association name.

In earlier provisional Montana classifications, Elymus lanceolatus and Pascopyrum smithii (western wheatgrass) have been characterized as ecological equivalents. They do have similar stature and productivity relative to their cover measured in point transect methods (Coupland 1950), and are often present in the same landscape. However, Elymus lanceolatus favors lower temperatures, less droughty conditions, and assumes prevalence at higher latitudes (Coupland 1950). It was observed to form associations of much higher density and resulting net productivity than Pascopyrum smithii in Sheridan Co., MT (Heidel et al. 2000) and is the only one of the two that dominates upland associations with such high cover values. Where they are sympatric, and dominants in contiguous associations, they tend to sort out by slope position and aspect.

\title{
Element Sources
}

Author(s): Heidel, B. S. V. Cooper and C. Jean, MTNHP Confidence: 2

References: Cooper et al. 2001, Heidel et al. 2000

\author{
Elymus lanceolatus - Elymus trachycaulus Herbaceous Vegetation \\ Thickspike Wheatgrass - Bearded Wheatgrass Herbaceous Vegetation \\ Global Rank: G? State Rank: S2S3? \\ Element Code (state provisional): CEGLMTHP58
}

\section{Element Concept}

Summary: This putative association is found as small patches on lower slopes, toeslopes, and alluvial flats. Soils appear to be well developed and the predominant soil texture was silt loam. The cover of both Elymus trachycaulus (bearded wheatgrass) and Elymus lanceolatus (thickspike wheatgrass) varies widely, from just barely well-represented (5\%) to 50-70\% cover, however, either singly or in combination, they form a comparatively dense sward. Other graminoids regularly occurring, but with less than 
$10 \%$ cover, include Nassella viridula (green needlegrass), Carex duriuscula (needleleaf sedge), and Koeleria macrantha (prairie junegrass). The most commonly occurring forbs are Vicia americana (American vetch), Sphaeralcea coccinea (scarlet globe-mallow), and Pediomelum argophyllum (silverleaved scurf-pea). Artemisia frigida (fringed sage) is present, usually with less than 5\% cover, and on the alluvial settings Artemisia cana (silver sagebrush) is present as scattered, ragged individuals.

Comments: The cover of Elymus lanceolatus can approach low values (in the vicinity of 5\%) and that of Elymus trachycaulus is usually considerably higher. However, the name advanced for the type with Elymus lanceolatus paramount seeks to align this type with the myriad Elymus lanceolatus associations that are described from the northern Great Plains. This type may be similar to Pascopyrum smithii (Elymus trachycaulus) Clay Pan Herbaceous Vegetation described for the Dakotas and possibly occurring in Saskatchewan, though the environmental descriptors only partially overlap. Heidel et al. (2000) have tentatively identified in Sheridan County, MT situations where Elymus lanceolatus is dominant and Elymus trachycaulus is absent; these habitats appear to have a higher moisture status (as revealed in presence of Muhlenbergia richardsonis (mat muhly), Panicum virgatum (switchgrass), Distichlis spicata (inland saltgrass), etc.) than the type we are describing for the project area. Determining whether this species assemblage repeats across a greater extent can only be revealed by future inventory.

\section{Element Sources}

Author(s): B. Heidel, S. V. Cooper and C. Jean, MTNHP Confidence: 3

References: Cooper et al. 2001, Heidel et al. 2000

Elymus lanceolatus - Nassella viridula Herbaceous Vegetation

Thickspike Wheatgrass - Green Needlegrass Herbaceous Vegetation

Global Rank: G3G4? State Rank: S3S4?

Element Code: CEGLMTHP57

\section{Element Concept}

Summary: This community was almost certainly one of the highly productive grassland types of the Northern Glaciated Plains that have been largely put under the plow. It occurs on upland positions having fine-textured soils with a high moisture holding capacity as well as various slope positions with an augmented moisture supply or reduced evapotranspiration (northerly-facing slopes). Elymus lanceolatus (thick-spike wheatgrass) and Nassella viridula (green needlegrass) are dominant with a combined cover in excess of $80 \%$ on the best sites. The shrub, subshrub and forb components are usually of negligible contribution, except where overgrazing has altered composition, usually in favor of the subshrub Artemisia frigida (fringed sage).

Environment: Elymus lanceolatus - Nassella viridula (thick-spike - green needlegrass) is found on a broad variety of topographic positions, from rolling upland of low to moderate relief to swales, breaklands, and moderate to steep coulee slopes with cooler aspects. It occurs on protected exposures, moister or water receiving positions in the landscape that possess fine-textured soils, though frequently a thin mantle of glacial drift may cover the sedimentary substrates which provide the majority of the rooting medium. This type often grades to Hesperostipa comata - Bouteloua gracilis (needle-andthread - blue grama), Hesperostipa comata - Carex filifolia (thread-leaved sedge) on sites with greater moisture stress or Pascopyrum smithii - Bouteloua gracilis (western wheatgrass - blue grama) on adjacent flats with fine-textured soils and Artemisia cana (silver sagebrush)-dominated or 
Symphoricarpos occidentalis (western snowberry) communities on swales and other lowland, moisturereceiving positions.

Vegetation: Elymus lanceolatus and Nassella viridula occurring well represented are diagnostic for this type, however fenceline contrasts indicate that both species can be reduced to trace amounts and even extirpated by intensive grazing. Ascertain the intensity of grazing before relaxing cover criteria for type identification. On lightly grazed rolling terrain Elymus lanceolatus cover approaches 95\%. Nassella viridula was chosen as an indicator of "favorable habitats" being associated with "heavy soil, by protection from wind, or by extra moisture from runoff." (Coupland 1961); where not abusively grazed, Nassella viridula cover may approach 20\%. Bouteloua gracilis and Carex filifolia (Hesperostipa comata) on sites with better drainage) are capable of dramatic increase with grazing and prolonged drought (Coupland 1961). Various mixes of Carex (sedge) spp., Carex duriuscula (needleleaf sedge), Carex filifolia, Carex inops (sun or long-stolon sedge) and Koeleria macrantha (prairie junegrass) are highly constant and range widely in cover values.

Selaginella densa (compact clubmoss) cover is high (> 70\%) on some severely overgrazed lands; other overgrazed sites support only trace amounts. High constancy forbs include Phlox hoodii (Hood's phlox), Sphaeralcea coccinea (scarlet globe-mallow), Antennaria parvifolia (Nuttall's pussy-toes), Vicia americana (American vetch) and Pediomelum argophyllum (silver-leaved scurfpea). Artemisia frigida (fringed sage) is the only shrub with greater than $50 \%$ constancy; on overgrazed pastures its cover approaches $20 \%$.

Comments: We have recognized Elymus lanceolatus - Nassella viridula (thick-spike wheatgrass green needlegrass) as an entity separate from Pascopyrum smithii - Nassella viridula (western wheatgrass - green needlegrass) due to an increased understanding of the ecologies of the component species. Elymus lanceolatus - Nassella viridula was probably a major community type throughout the northwestern Great Plains (Coupland 1961) but has been put to the plow because of its favorableness for agriculture. Its occurrence is also much reduced and degraded because the gentle terrain affords ready access to livestock. Intensive grazing of this association has resulted in much conversion to Hesperostipa comata - Bouteloua gracilis and Pascopyrum smithii - Bouteloua gracilis plant associations or weed-dominated community types with a high percentage of introduced annual grasses, e.g. Bromus japonicus (Japanese brome), Bromus tectorum (cheatgrass), Festuca octoflora (six-weeks fescue).

Dynamics: Observation of postfire succession in northern Montana indicates that four years following a burn the dwarf-shrub component had yet to establish. Regarding response of grasses, lack of preburn inventory renders observations as mere conjecture, but rhizomatous grass cover of burned areas appeared more lush with greater biomass than unburned. There appeared to be no increased mortality for bunchgrasses, rather, they appeared taller and more robust. Native disturbance increasers, e.g. Collomia linearis (narrow-leaf collomia), Hedeoma hispidum (rough pennyroyal), Lepidium (pepperweed) spp, are a minor, non-threatening component, but Eurasian aliens, e.g. Camelina macrocarpa (littlepod falseflax), Melilotus officinalis (yellow sweetclover), Bromus japonicus, and Bromus tectorum, constitute a significant liability to community integrity and values. Bromus japonicus currently constitutes the greatest threat to native diversity due to its considerable presence in the landscape. If an analogy can be made between the ecology and disturbance response of Bromus japonicus and that of Bromus tectorum, then with successive fires (or continued abusive grazing practices) Bromus japonicus will markedly increase its cover relative to that of the native species component (Mack 1984). The aggressiveness of the biennial Melilotus officinalis is much greater than originally appreciated, when it was used indiscriminately to revegetate burns and other disturbances and planted as dense nesting cover. 


\section{Similar Associations:}

- Pascopyrum smithii - Nassella viridula Herbaceous Vegetation (CEGL001583)

\section{Synonymy:}

- Agropyron - Koeleria (macrantha) faciation (Coupland 1961)

-Agropyron smithii - Nassella viridula - Bouteloua gracilis community type (Whitman 1976)

Grank \& Reasons: G3?

The areal extent of this type has not been thoroughly documented however, given its landscape position and soils highly favorable for agriculture, it is highly probable that much of this community type has been plowed under.

Comments: Data presented by Quinnald and Crosby (1958) for ungrazed North Dakota mesas shows Nassella viridula to be an important component of Pascopyrum smithii- and Elymus lanceolatusdominated stands and Whitman (1976) documents a AGRSMI-STIVIR-BOUGRA c.t from southwestern ND occurring on silty clays, clay loams, and clays. For the prairies of Alberta the community closest in composition is wheatgrass dominated (predominantly Elymus lanceolatus) and known as the "Agropyron-Koeleria (macrantha) faciation" which Coupland (1961) describes as having a Nassella viridula component on the more mesic positions; it is described as occurring only on rolling terrain with lacustrine clay soils.

\section{Element Distribution}

Range: Though documented from only from Montana and Norh Dakota, this community is strongly speculated to be found across the northwestern Great Plains of the United States and Canada, ranging from Montana to Saskatchewan and possibly Manitoba.

States / Provinces: AB: S?, MB: S?, MT: S3S4?, ND: S?, SK: S?

Element Sources

Authors: S. V. Cooper \& C. Jean, MTNHP Confidence: 2

References: Coupland 1961, Quinnald \& Crosby 1958, Whitman 1976

Eriogonum pauciflorum - Gutierrezia sarothrae Badlands Sparse Vegetation

Few-flowered Wild Buckwheat - Broom Snakeweed Badlands Sparse Vegetation

Global rank: G4G5 State rank: S3S4?

Element Code: CEGL005270

\section{Element Concept}

Summary: The few-flowered wild buckwheat - broom snakeweed Badlands sparse vegetation represents an outcrop or scabland feature of the northern Great Plains in Montana, North Dakota and South Dakota. It occurs on unconsolidated or poorly consolidated sedimentary formations that are easily eroded, including siltstones, mudstones, and shales (particularly acid shales). Slopes that become stabilized revegetate to grassland with succession. This badlands plant association type rarely exceeds $10 \%$ vegetative cover and is often less than $5 \%$ hence it is technically placed in a sparse vegetation classification category rather than a grassland plant association. On level terrain, the vegetation is relatively evenly distributed, but on steeper slopes and cliffs the vegetation may grow in patches and in rows or seams. Plant species that are nearly always present include Eriogonum pauciflorum (few- 
flowered buckwheat), Gutierrezia sarothrae (broom snakeweed), Opuntia polyacantha (plains pricklypear), Chrysothamnus nauseosus (common rabbitbrush), Atriplex argentea (silverscale), a cryptantha (Cryptantha thyrsifolia), a characteristic plant at least in South Dakota), and the forb Grindelia squarrosa (gumweed). In the study area this community is restricted to the most exposed and rugged breaks of the Frenchman, Rock, Crow and Bitter Creek drainages and major tributaries cutting into bedrock and also occurs on low gradient outwash fans within the same drainages.

Environment: In Badlands National Park, South Dakota, this type is typically found on silty/sandy outwash fans newly deposited by eroding badlands formations. These formations include Cretaceous Pierre shale, Oligocene Brule siltstone and Chadron clayey mudstone and shale, and Miocene Arickaree sandstone. Soils are undeveloped, poor, loose, and easily eroded. The topography is typically flat, and stands occur on erosional outwash fans. One stand, comprised of four-wing saltbush, occupies a large badlands flat and erosion fan (Von Loh et al. 1999).

Vegetation: This badlands community type rarely exceeds $10 \%$ vegetative cover and is often less than $5 \%$. On level terrain, the vegetation is relatively evenly distributed, but on steeper slopes and cliffs the vegetation may grow in patches and in rows or seams. In Badlands National Park, plant species that are nearly always present include the dwarf-shrubs Eriogonum pauciflorum, Gutierrezia sarothrae, Opuntia polyacantha, Atriplex argentea, and Cryptantha thyrsiflora, and the forb Grindelia squarrosa. Atriplex canescens dwarf-shrubs were observed throughout the type, but were typically short-statured and scattered in distribution (Von Loh et al. 1999).

Comments: Few-flowered wild buckwheat is considered to be a "sub-shrub", thus, the plant association is included among shrub-dominated plant associations. This association encompasses the "Chrysothamnus nauseosus / Eriogonum pauciflorum plant association type" previously described in southeastern Montana where sparse badlands vegetation is more common (Vanderhorst et al. 1998)

\section{Element Distribution}

Range: This badlands type is found in the northwestern Great Plains in badlands topography.

States/Provinces: MT:S3S4?, ND:S?, SD:S?

\section{Element Sources}

Authors: D. Faber-Langendoen, MCS, mod. S.V. Cooper \& C. Jean, MTNHP Confidence: 2

References: Von Loh et al. 1999, Cooper et al. 2001, Vanderhorst et al. 1998

\section{Hesperostipa curtiseta - (Elymus lanceolatus) Herbaceous Vegetation}

Northern Porcupine Grass - (Thick-spike Wheatgrass)

Global Rank: G? State Rank: S2?

Element Code: CEGL002253

\section{Element Concept}

Summary: The northern porcupine grass- thickspike wheatgrass plant association is a highly productive prairie type of sheltered hillslopes in prairie pothole and prairie parkland regions and also occurs as matrix community of rolling prairie landscapes of the provinces and adjoining northern Great Plains states. It is quite likely that it occupied some of the richest agricultural land in the northern Great Plains (typified by deep Mollisols) and that virtually all of it has been put under the plow. A few remnant areas in northern Valley County show that given the proper soils it can occur on gently rolling 
to flat terrain; the same environment, termed the dark-brown soil zone, is occupied by this association, termed the Stipa - Agropyron community in the literature of the Canadian prairies (Coupland 1992). Generally it is rich in species numbers, particularly forbs, and includes grasses and forbs that are restricted to or reach their peak frequency in this association, compared with surroundings.

Environment: This association has been documented as occurring primarily on glacial till on which deep loamy soils have developed on cool, moist north-facing slopes or in swale positions that probably receive in excess of normal precipitation through snow deposition. However, there are a couple of Valley County landscapes where this association occurs on gently rolling to flat terrain, associated with silty loam Mollisols, also a till- and drift-mantled landscape. These occurrences probably represent how the majority of this association was distributed as a matrix type prior to settlement. Regardless of position in the landscape the soils are well drained and mantled by a deep and continuous litter layer with little or no soil and rock exposed.

Vegetation: Combined graminoid canopy cover of this association frequently exceeds $80 \%$ and Hesperostipa curtiseta (northern porcupine grass), the diagnostic graminoid with at least 5\% canopy cover, is also usually the herbaceous dominant. However, plots with both Elymus lanceolatus (thickspike wheatgrass) and Nassella viridula (green needlegrass) dominant have been recorded. The Bitter Creek / Frenchman Creek landscape of north-central Montana differs from some other sampled Montana locations in that Elymus lanceolatus or even Nassella viridula can be dominant and certainly they have higher constancy values here than in the type's Sheridan Co. expression. Koeleria macrantha (prairie junegrass), Carex duriuscula (needleleaf sedge), Carex filifolia (threadleaved sedge), Carex inops (sun sedge) and Bouteloua gracilis (blue grama) all have constancy values in excess of $40 \%$ and the sedges named may have cover values in excess of $10 \%$. The forb cover is diverse and varies by locality with Pediomelum argophyllum (silver-leaved scurfpea), Achillea millifolium (common yarrow), Geum triflorum (old man's whiskers) and Anemone patens (pasque flower) being particularly constant and occasionally having cover in excess of 5\%. Shrub cover may include scattered sprigs of Rosa arkansana (prairie rose) and Symphoricarpos occidentalis (western snowberry) and very limited amounts $(<2 \%)$ of Artemisia frigida (fringed sage), ostensibly where grazing has been intensive.

This is one of the few associations where Selaginella densa (compact clubmoss) does not form nearly continuous mat, in fact it was absent in over $30 \%$ of the plots and averaged only $25 \%$ cover in the plots in which it occurred. Redmann (1975) described a unique feature, an abundance of moss in the undergrowth, and this feature has been established by Heidel et al. (2000) to occur as well in Sheridan Co. and this study noted this phenomena as well, but the moss was obviously more abundant on north slopes.

Dynamics: The Juniperus horizontalis / Hesperostipa curtiseta - (Elymus lanceolatus) association develops on moderate to steep, north-facing slopes and general observation indicates that Juniperus horizontalis, the primary site colonizer and stabilizer, may slowly die out leaving an intact and stable Hesperostipa curtiseta - (Elymus lanceolatus) community.

\section{Synonymy:}

- Stipa - Agropyron Community (Coupland 1992)

- Hesperostipa curtiseta - Nassella viridula Association (DeVelice et al. 1995)

- Hesperostipa curtiseta - Elymus lanceolatus Association (Cooper and Heidel 1999; CEGL002253 from Midwest classification)

- Hesperostipa curtiseta Herbaceous Vegetation (Heidel et al. 2000)

GRank \& Reasons: G? 
Though this type (of ones of comparable synonymy) has been referenced in literature for some time it is being formally proposed, based on a considerable accumulation of detailed plots. Sampling in the mid to late 1990's has documented it across a few of the northern tier of Montana's counties and ranging into North Dakota and with but one known exception as a small patch community (in portions of landscape capable of being plowed only with difficulty). It is speculated to be a remnant type both here and in Canada. The rank should be re-evaluated following input from Canadian ecologists.

Comments: This association has been described from plots taken in Montana alone; clearly it occurs with greater abundance in the Alberta and Saskatchewan prairies and a more encompassing description awaits the analysis and incorporation of the Canadian observations.

The type we describe here corresponds with the Stipa spartea var. curtiseta - forb community of Redmann (1975) that was based on one north-facing plot in western North Dakota, north of the Missouri River. In Sheridan County this type has been previously described as both Hesperostipa curtiseta - Elymus lanceolatus (Cooper and Heidel 1999) and as Hesperostipa curtiseta Herbaceous Vegetation (Heidel et al. 2000) and for the northeastern corner of Montana. DeVelice et al. (1995), characterized a Hesperostipa curtiseta - Nassella viridula association that is essentially synonymous with the type described here. We determined that the ecological conditions subsumed under the various association names above are essentially constitute a distinct partition of the environmental gradient, possess a similar floristic assemblage and should be recognized by one name, Hesperostipa curtiseta - (Elymus lanceolatus). The parentheses are used to indicate that Elymus lanceolatus is not always present in a stand but still constitutes a useful descriptor of the association.

\section{Element Distribution}

Range: This midgrass prairie type is found in the western and northern Great Plains, ranging from Manitoba westward through eastern Alberta and south to North Dakota and Montana.

States/Provinces: AB:S?, MB:S?, MT:S2?, ND:S?, SK:S?

\section{Element Sources}

Authors: Heidel, B., S. V. Cooper \& C. Jean, MTNHP Confidence: 2

References: Cooper and Heidel 1999, Cooper et al. 2001, DeVelice et al. 1995, Heidel et al. 2000, Redman 1975

Juniperus horizontalis / Calamovilfa longifolia Dwarf-shrubland

Creeping Juniper / Prairie Sandreed Dwarf-shrubland

Global Rank: G? State Rank: S2?

Element Code: CEGLMTHP50

\section{Element Concept}

Summary: The creeping juniper / prairie sandreed association is a minor, small patch type associated with badland topography (principally within the Bitter Creek Badlands) northwest of Glasgow, MT but has also been documented from shale breaklands within the Charles M. Russell National Wildlife Refuge. It can probably be expected in similar settings with highly erosive shale-dominated substrates. Whether found on butte tops or slopes, toeslopes, colluvial flats, or even alluvial bottoms, erosion is the dominant process (mostly sheet and rill) producing up to $90 \%$ exposed substrate. Soils lack any horizonation and are predominantly single-grained. Even though derived from shales or siltstones are dominated by sand and larger-sized particles. We speculate that this type is a relatively early seral stage 
of other Juniperus horizontalis-dominated types (e.g. Juniperus horizontalis / Elymus lanceolatus or Juniperus horizontalis / Hesperostipa curtiseta) or possibly grassland associations. Though seemingly anomalous, we recorded at least one instance of this association occupying what we took to be a wetland site with gleyed and mottled soils! Juniperus horizontalis is well represented but coverages are on average not so high as in other Juniperus horizontalis-dominated types. Calamovilfa longifolia (prairie sandreed) and Calamagrostis montanensis (plains reedgrass) are both $100 \%$ constant and well represented whereas Schizachyrium scoparium (little bluestem) is highly constant but occurs in trace amounts. Forb composition and cover is depauperate with the highly constant Thermopsis rhombifolia (roundleaved thermopsis) and Solidago nemoralis (gray goldenrod) being most characteristic of the type.

\section{Element Source}

Author(s): Cooper, S. V. and C. Jean, MTNHP Confidence: 3

References: Cooper et al. 2001

Juniperus horizontalis / Elymus lanceolatus Dwarf-shrubland

Creeping Juniper / Thickspike Wheatgrass Dwarf-shrubland

Global Rank: G? State Rank: S3?

Element Code: CEGLMTHP44

\section{Element Concept}

Summary: Stands dominated by creeping juniper in association with thick-spike wheatgrass have been documented from the Big Muddy headwaters of Sheridan County westward to the upper Frenchman Creek drainage of Valley County but its most extensive expression has been noted on the coulees feeding into the Bitter Creek Badlands landscape. It generally occurs as small to large patch communities on sheltered, north-facing slopes on silt loam derived from shale or other fine-textured parent material. However it has been recorded alluvial terraces to all variety of slope features from toeslopes to slope shoulders, but never on warmer aspects. Ground cover characteristics varied widely, the most typical situation being a high percentage of exposed soil $(>60 \%)$ due to sheet and rill erosion or low gradient slopes and flats having a nearly continuous litter layer. Erosion has apparently impact all sites either stripping or depositing eroded materials. Sites notably lack a Selaginella densa (compact clubmoss) layer that might protect against erosion. Shrub cover ranges widely (from 10 to $70 \%$ ), averaging about $45 \%$ comprised almost wholly of Juniperus horizontalis (creeping juniper); Dasiphora fruticosa ssp. floribunda (shrubby cinquefoil), Symphoricarpos occidentalis (western snowberry), Rosa spp. (rose) and Artemisia cana (silver sagebrush) are all at least 50\% constant. Elymus lanceolatus (thickspike wheatgrass) is $100 \%$ constant, usually dominant and diagnostic at the well represented level, but in some areas shares dominance with Pascopyrum smithii (western wheatgrass). The diversity of graminoids present is high, the most constant being Koeleria macrantha (prairie junegrass, 100\%), Nassella viridula (green needlegrass) and Calamagrostis montanensis (plains reedgrass).

Though having lower constancy values than the previously cited graminoids, several sedges are capable of occurring in coverages up to $20 \%$ including Carex inops (sun sedge), Carex filifolia (threadleaf sedge) and Carex duriuscula (needleleaf sedge). Herbaceous species diversity is high; included among the more characteristic are Hedysarum boreale (northern hedysarum), Geum triflorum (old man's whiskers), Oxytropis campestris (slender crazyweed), Campanula rotundifolia (harebell), pasqueflower (Anemone patens), Phlox hoodii (Hood's phlox), Erigeron cespitosus (tufted fleabane) and Vicia americana (American vetch). 
Classification Comments: The forb component of this plant association resembles that for the Hesperostipa curtiseta - (Elymus lanceolatus) ( porcupine grass - (thickspike wheatgrass)) Herbaceous Vegetation, Juniperus horizontalis / Hesperostipa curtiseta - (Elymus lanceolatus) Dwarf-shrubland (creeping juniper / porcupine grass - western wheatgrass) and the Dasiphora fruticosa ssp. floribunda / Hesperostipa curtiseta Dwarf-shrubland (shrubby cinquefoil / northern porcupine grass) plant associations, confirming that all these types are characteristic of the most mesophytic of upland environments.

\section{Element Sources}

Author(s): Cooper, S. V. and C. Jean, MTNHP Confidence: 3

References: Cooper et al. 2001

Juniperus horizontalis / Elymus trachycaulus Dwarf-shrubland

Creeping Juniper / Bearded Wheatgrass Dwarf-shrubland

Global Rank: G? State Rank: S2S3?

Element Code: CEGLMTHP58

\section{Element Concept}

Summary: This is a minor, small patch forming dwarf-shrubland that has been documented from the badlands or highly erodible terrain in northern Phillips County, specifically from the Frenchman Creek and Crow Creek drainages and the Bitter Creek Badlands. This putative association is both in composition and environment very much like Juniperus horizontalis / Elymus lanceolatus; it occurs on protected, cool exposures usually on lower slope to toeslope positions where parent materials are shales and siltstones (with and without a mantle of glacial drift). Frequently there are erosion patches present where apparently the Juniperus horizontalis has died out and loss of rootmass integrity permits sheet and rill erosion. Pedicelling is also notable in some cases. Erosion rates are such that soils apparently do not develop. The cover of Juniperus horizontalis is highly variable, usually in excess of $60 \%$ but as low as 10\% and Rosa spp. (roses), Symphoricarpos occidentalis (western snowberry) and Artemisia frigida (fringed sage) are the only woody species consistently present. The graminoid component, which was not observed to exceed 30 to $40 \%$ cover, is dominated by Elymus trachycaulus; also present in much lesser amounts is a variable assemblage of Elymus lanceolatus (thickspike wheatgrass), Pascopyrum smithii (western wheatgrass), Carex duriuscula (needleleaf sedge), Carex filifolia (threadleaf sedge) and Koeleria macrantha (prairie junegrass). Forb diversity is low to moderate and cover of any one species seldom exceeds trace amounts; Thermopsis rhombifolia (prairie goldenbean) Galium boreale (northern bedstraw) and Antennaria parvifolia (Nuttall's pussytoes), all increasers with grazing, are the only forbs with high constancy.

\section{Element Sources}

Author(s): Cooper, S. V. and C. Jean, MTNHP Confidence: 3

References: Cooper et al. 2001 
Juniperus horizontalis / Juncus balticus Dwarf-shrubland

Creeping Juniper / Baltic Rush Dwarf-shrubland

Global Rank: G? State Rank: S2S3?

Element Code: CEGLMTHP53

\section{Element Concept}

Summary: Juniperus horizontalis / Juncus balticus is a minor community described only from the badlands northwest of Glasgow, MT. In this highly dissected landscape this type occurs as small patches on narrow alluvial benches intercalated between drainages and upslope positions; it frequently extends to toeslope positions of north-facing slopes. Substrates are alluvium (stream and slope-wash depositions) derived from shales, siltstones and may include contributions from eroded bentonite deposits. All plots had weakly mottled and gleyed soil (at approximately $20 \mathrm{~cm}$ downward) which points to there quite probably being wetland sites. These sites are subject to erosion through overland flow but due to cladding effect of high Juniperus horizontalis coverages the erosion amounts are minimal, less than $5 \%$ of the surface area. Adjacent sites are often part of a Juniperus horizontalisdominated complex, including Juniperus horizontalis / Schizachyrium scoparium (creeping juniper / little bluestem) and Juniperus horizontalis / Calamovilfa longifolia (creeping juniper / prairie reedgrass).

Vegetation: Juniperus horizontalis coverage generally exceeds $30 \%$ and is noted to completely blanket some sites. Rosa spp. (roses), are 100\% constant. Juncus balticus is at least well represented, often abundant. Calamagrostis montanensis (plains reedgrass), Calamovilfa longifolia and Schiachyrium scoparium (little bluestem) were 100\% constant and even occasionally more abundant than Juncus balticus. The combined cover of graminoids appears to be inversely related to Juniperus horizontalis cover. Thermopsis rhombifolia (roundleaved thermopsis), Achillea millifolium (common yarrow) and Antennaria neglecta (field pussytoes) are characteristic of a depauperate forb layer; only Thermopsis rhombifolia occurs well represented.

Comments: Juniperus horizontalis / Juncus balticus has not been previously described, nor has Juniperus horizontalis been previously identified as a wetland dominant. Juncus balticus is associated with anthropogenically modified wetlands (Hansen et al. 1995) but not even trace amounts of possibly displaced previous true wetland species (graminoids) could be found on sampled sites. Though other graminoids have been noted to have higher coverages within this association, it is recognized by and named for Juncus balticus based on the interpretation of its acknowledged indicator value as a facultative wetland species. Because the requisite soil and hydrological characterizations were not performed this type cannot be said to occupy wetland environments, except by implication from the presence of Juncus balticus.

\section{Element Sources}

Author(s): Cooper, S. V. and C. Jean, MTNHP Confidence: 3

References: Cooper et al. 2001 
Juniperus horizontalis / Schizachyrium scoparium Dwarf-shrubland

Creeping Juniper / Little Bluestem Dwarf-shrubland

Global Rank: G4 State Rank: S4

Element Code: CEGL001394

\section{Element Concept}

Summary: This creeping juniper community type is found in the northwestern Great Plains of the United States and Canada. Stands occur on moderate to steep slopes, usually on upper slopes. Soils are silty loam, sandy loam, or clay loam. In North Dakota, Montana, and South Dakota it occurs on northand, rarely, west facing slopes. In Manitoba it is thought to occur on dry south-facing slopes. Parent materials are sandstone, siltstone, claystone, and sandy glacial till. This community is dominated by short shrubs and graminoids. Vegetation cover is moderate to high. The dominant species is usually Juniperus horizontalis, a mat-forming shrub. Other low shrubs include Artemisia frigida, Dasiphora fruticosa ssp. floribunda, Symphoricarpos occidentalis, and Rosa arkansana. Rhus trilobata and Prunus virginiana are taller shrubs that may be present. The most abundant graminoid is Schizachyrium scoparium. Other common graminoids include Calamovilfa longifolia, Carex filifolia, Carex inops ssp. heliophila, Carex duriuscula, Koeleria macrantha, and Muhlenbergia cuspidata. Some of the forbs that are associated with this community are Anemone patens, Campanula rotundifolia, Comandra umbellata, Echinacea angustifolia, Dalea purpurea, Galium boreale, Senecio plattensis, and Linum perenne.

Environment: Stands occur on moderate to steep slopes, usually on upper slopes (Hansen et al. 1984, USFS 1992). Typically, in the northern plains, stands occur on north and, rarely, west-facing slopes (Johnston 1987), but in Manitoba it is thought to occur on dry south-facing slopes (Greenall 1995). Parent materials are sandstone, siltstone, claystone, and sandy glacial till (USFS 1992). Soil textures include shallow silty loam, sandy loam, or clay loam soil. Hirsch (1985) reported significant amounts of gravel and scoria near the surface.

Vegetation: This community is dominated by short shrubs and graminoids. Vegetation cover is moderate to high. The U.S. Forest Service (1992) found that in 11 stands in western North Dakota the average cover of shrubs was $44 \%$, graminoids covered $32 \%$, and forbs $2 \%$. The dominant species is usually Juniperus horizontalis, a mat-forming shrub. Other low shrubs include Artemisia frigida, Dasiphora fruticosa ssp. floribunda, Symphoricarpos occidentalis, and Rosa arkansana. Rhus trilobata and Prunus virginiana are taller shrubs that may be present. The most abundant graminoid is Schizachyrium scoparium. Other common graminoids include Calamovilfa longifolia, Carex filifolia, Carex inops ssp. heliophila, Carex duriuscula (= Carex eleocharis), Koeleria macrantha, and Muhlenbergia cuspidata. Some of the forbs that are associated with this community are Pulsatilla patens (= Anemone patens), Campanula rotundifolia, Comandra umbellata, Echinacea angustifolia, Dalea purpurea, Galium boreale, Senecio plattensis, and Linum perenne. Bare ground may occupy 25$45 \%$ of the surface (Hirsch 1985).

Comments: Preliminary analysis and classification recognized two plant associations dominated respectively by scoparium and Pseudoroegneria spicata. Subsequent analysis could not establish that their site parameters were different and continuous variations in relative dominance between the two diagnostic species resulted in a merging of the two types. The Schizachyrium scoparium name was chosen for the type because of this species' higher constancy and cover values. The examples of this type within northeastern Montana are compositionally intermediate between Juniperus horizontalis / Carex inops described for southeastern Montana and contiguous portions of North and South Dakota (Hansen and Hoffman 1988) and Juniperus horizontalis / Andropogon scoparius described for western North Dakota (Hansen et al. 1984). Both associations occur as topoedaphic climaxes on steep, north- 
facing slopes with sandy substrates. Miller's (1978) extensive Juniperus horizontalis study includes plots (identified as Juniperus horizontalis / Pseudoroegneria spicata and Juniperus horizontalis / Schizachyrium scoparium - Festuca idahoensis) that would be placed in the Juniperus horizontalis / Schizachyrium scoparium type as we have defined it herein. Juniperus horizontalis-dominated vegetation has been described for Alberta (Coupland) but not south of Montana. It is speculated Juniperus horizontalis / Carex inops ssp. heliophila Dwarf-shrubland may be an early seral stage of Juniperus horizontalis / Schizachyrium scoparium Dwarf-shrubland (D. Ode pers. comm.)

Study Area Comments: Within the study area this type occurs as small patches $(<1$ acre $)$, often as part of a Juniperus horizontalis-dominated complex in the midst of badlands or breaklands or less commonly gently rolling terrain. It develops mostly on benches (alluvial or outwash terraces) but positions included toeslopes, footslopes and backslopes (to the crest). Substrates are sedimentary, mostly shales and siltstones decomposed to gravelly sands composed of shale shards (fines outwashed?) or glacial drift. These sites are highly erosive and where Juniperus horizontalis cover is low extensive sheet, rill, and even gully erosion obtains. Even where sites are apparently stabilized by appreciable vegetative cover $(>70 \%)$ erosion yet encroaches from all sides due to alluvial/colluvial processes from below and wind-generated blowouts from about and the sides. Juniperus horizontalis / Schiachyrium scoparium is often found in a complex with Juniperus horizontalis / Juncus balticus (creeping juniper / Baltic rush) that occupies moister positions, Juniperu horizontalis / Elymus lanceolatus (creeping juniper / thickspike wheatgrass) on more stabilized positions, Juniperus horizontalis / Calamovilfa longifolia (creeping juniper / prairie sandreed) on ostensibly coarser substrates and it commonly grades to Elymus lanceolatus - Hesperostipa comata, Pascopyrum smithii - Hesperostipa comata, or Pascopyrum smithii - Boutelous gracilis that occupy more stabilized sites on the periphery of the badlands (or erodeable landscapes).

Study area vegetation generally accords with the general description; Juniperus horizontalis dominates the shrub layer, exhibiting widely varying coverages (10-80\%). Rosa arkansana (prairie rose), Artemisia frigida (fringed sage) and Gutierrezia sarothrae (broom snakeweed) are the only shrubs (subshrubs) having greater than $50 \%$ constancy though their cover seldom exceeds $3 \%$. The graminoid component is dominated by Schizachyrium scoparium and/or Pseudoroegneria spicata (bluebunch wheatgrass) with coverages of both running the gamut of 1 to $60 \%$; other graminoids with high constancy include Carex filifolia (threaleaf sedge), Calamovilfa longifolia (prairie sandreed) and Koeleria macrantha (prairie junegrass). Though poorly represented, the mere presence of Juncus balticus (Baltic rush) and Elymus lanceolatus (thickspike wheatgrass) indicates transitions to moister sites. The forb component is relatively depauperate and apparently lacks any characteristic species; Thermopsis rhombifolia was well represented in about $30 \%$ of the plots.

\section{Element Sources}

Authors: J. Drake, MCS; mod. S. V. Cooper \& C. Jean, MTNHP Confidence: 1

References: DeVelice et al. 1991, Greenall 1995, Hansen et al. 1984, Hirsch 1985, Johnston 1987, Montana Natural Heritage Program 1988, U.S. Forest Service (USFS) 1992 
Juniperus horizontalis / Hesperostipa curtiseta - (Elymus lanceolatus)

Dwarf-shrubland

Creeping Juniper / Northern Porcupine Grass - Western Wheatgrass)

Global Rank: G? State Rank: S3?

Element Code: CEGLMTHP54

\section{Element Concept}

Summary: This is a minor, small patch community that has been described only from northwestern Valley County, most commonly associated with the northerly-facing slopes of coulees and drainage headwaters feeding into the Bitter Creek Badlands and Frenchman Creek landscapes. It has also been found in swales and toeslope positions. This type has been found only on erosive shale or siltstone parent material; the moderately dense vegetative cover and dense network of Juniperus horizontalis prevents the extensive development of rills seen in some other Juniperus horizontalis-dominated stands on these types of parent materials. Where the type occurs on slopes sheet erosion is clearly present with pedicelling of stems and grass tussocks as well as downslope deposition tending to bury some stands. The vegetation composition is very similar to that of the Juniperus horizontalis / Elymus lanceolatus association, differing principally by the high coverage of Hesperostipa curtiseta $(>30 \%)$ and to a lesser degree by the relatively greater importance of Nassella viridula (green needlegrass) and Carex duriuscula (needleleaf sedge). Other graminoids with high constancy include, Koeleria macrantha (prairie junegrass), Carex inops (sun sedge), and Carex. filifolia (thread-leaved sedge). Forb diversity is high and seldom does one or more species tend to dominate; forbs characteristic of these sites (and ones comparably mesic) include Geum triflorum (prairie smoke), Galium boreale (northern bedstraw), Dalea purpurea (purple prairie clover), Antennaria parvifolia (Nuttall's pussy-toes) and Vicia americana (American vetch). Selaginella densa (compact clubmoss) is usually conspicuously absent but coverages as high as $60 \%$ have been noted.

Comments: Juniperus horizontalis / Hesperostipa curtiseta - (Elymus lanceolatus) has strong compositional similarity to Juniperus horizontalis / Elymus lanceolatus and Juniperus horizontalis / Elymus trachycaulus (creeping juniper / bearded wheatgrass); these three associations differ principally in the dominant graminoid. All three types have closely similar abiotic descriptors. These types are not adequately substantiated by plot sampling, even from within the core area from which they have been described. It would be presumptuous at this point to declare the dominant graminoids to be ecological equivalents and merge the types into one.

\section{Element Sources}

Author(s): Cooper, S. V. and C. Jean, MTNHP Confidence: 3

References: Cooper et al. 2001

Juniperus scopulorum / Piptatherum micranthum Woodland

Rocky Mountain Juniper / Little-seed Mountain Ricegrass Woodland

Global Rank: G3G4 State Rank: S3

Element Code: CEGL000747

\section{Element Concept}

Summary: This rocky mountain juniper community type is found in the western Great Plains of the United States. Stands occur almost exclusively on steep (30-70\%) north-facing slopes. The soils are 
shallow and poorly developed; loamy sands and sandy loams predominate. The vegetation structure and composition is an evergreen woodland with moderately open to dense cover of Juniperus scopulorum or less commonly Juniperus virginiana (red cedar), or introgressed hybrids of the two. Woody species other than Juniperus scopulorum or Juniperus virginiana occur sporadically, but none achieves prominence. Most of the trees are small $(10-20 \mathrm{~cm} \mathrm{dbh})$ and few exceed $6 \mathrm{~m}$. in height. Where the density of the tree canopy is high, the short-shrub and herbaceous strata are not well developed. In more open places Piptatherum micranthum is often abundant. Other common herbaceous species include Campanula rotundifolia (harebell), Galium boreale (northern bedstraw), and Maianthemum stellatum (starry Solomon's seal). Mosses and lichens can cover much of the ground.

Environment: This community typically occurs on moderate to steep (16-70\%), north-facing slopes, but can occur on a variety of aspects (Johnston 1987, Von Loh et al. 1999). The soils are poorly developed, shallow, loamy sands, sandy loams, and clay loams, sometimes with high gravel content. These woodlands are frequently associated with outcrops of sandstone (DeVelice et al. 1995) or scoria and clay slopes (Girard et al. 1989).

Vegetation: This woodland community is dominated by small Juniperus scopulorum trees through most of its range, and is replaced by Juniperus virginiana and introgressant hybrids in the eastern portion of its range in Nebraska and South Dakota (Kaul et al. 1983, Von Loh et al. 1999). Acer negundo and Fraxinus pennsylvanica saplings are sometimes found in depressions where soil and moisture accumulate. Most of the juniper trees are 10-20 cm dbh and 4-6 meters tall, but some trees can be up to 30-40 $\mathrm{cm}$ dbh. The basal area has been reported at 22-29 $\mathrm{m} 2 / \mathrm{ha}$ in North Dakota and up to 22-41 m2/ha in southeastern Montana and northwestern South Dakota (Nelson 1961, Hansen et al. 1984, Hansen and Hoffman 1988). Tree canopy is moderate to dense, e.g., in North Dakota, Girard et al. (1989) measured densities of 975 trees/ha. Where the canopy is dense the shrub and herbaceous strata are poorly developed. Where the canopy is less full, shrubs and herbaceous species are more abundant, e.g. on 7 stands in southwest North Dakota mosses and lichens covered $72 \%$ of the ground surface, shrubs covered 17.4\%; graminoids 69.1\%, and forbs 9.4\% (Hansen et al. 1984). Among the shrubs that may be found in this community are Juniperus communis (common juniper), Juniperus horizontalis (creeping juniper), small Juniperus scopulorum (Rocky Mountain juniper) or Juniperus virginiana (red cedar), Mahonia repens (Oregon grape), Dasiphora fruticosa ssp. floribunda (shrubby cinquefoil), Prunus virginiana (common chokecherry), Rhus trilobata (skunkbush sumac), Ribes aureum (golden current), Ribes cereum (squaw current), Rosa woodsii (Wood's rose), Symphoricarpos albus (common snowberry), and Symphoricarpos occidentalis (western snowberry). Typical herbaceous species include Anemone patens (pasqueflower), Antennaria microphylla (rosy pussytoes), Campanula rotundifolia (harebell), Carex inops ssp. heliophila (sun sedge), Chenopodium fremontii (Fremont's goosefoot), Elymus lanceolatus (thickspike wheatgrass), Elymus trachycaulus (bearded wheatgrass), Galium boreale (northern bedstraw), Geum triflorum (prairie smoke), Koeleria macrantha (prairie junegrass), Piptatherum micranthum (littleseed ricegrass), Maianthemum stellatum (starry Solomon's seal), Parietaria pensylvanica (Pennsylvania pellitory), and Taraxacum officinale (common dandylion) (Hansen et al. 1984, Hansen and Hoffman 1988).

Comments: This description includes stands with both Juniperus scopulorum and Juniperus virginiana over a herbaceous layer dominated by Piptatherum micranthum. Pinus ponderosa (ponderosa pine), if present is less than 25\% tree canopy cover. Within the Bitter Creek/ Frenchman Creek study area the canopy is comprised almost exclusively of Juniperus scopulorum.

\section{Element Distribution}

Range: This rocky mountain juniper community type is found in the western Great Plains of the United States. It is found in the Black Hills and the Badlands of North and South Dakota and in 
Montana as far west as Phillips County, and from the High Plains of eastern Wyoming eastward to central Nebraska.

States/Provinces: MT:S3, ND:S3, NE:S4S5, SD:SU

Element Sources

Author(s): P.L. Hansen, G.R. Hoffman, and A.J. Bjugstad, mod. J. Drake and S. Rolfsmeier

Confidence: 1

References: DeVelice et al. 1995, Girard et al. 1989, Godfread 1994, Hansen 1985, Hansen and Hoffman 1988, Hansen et al. 1984, Johnston 1987, Kaul et al. 1983, Nelson 1961, Von Loh et al. 1999

Muhlenbergia cuspidata - Bouteloua gracilis Herbaceous Vegetation

Plains muhly - Blue Grama Herbaceous Vegetation

Global Rank: G? State Rank: S?

Element Code (state provisional): CEGLMTHP60

\section{Element Concept}

Summary: This provisionally defined association is found as a small patch community along gently to abruptly rounded slope shoulders of all but northerly aspects and upper slope positions with south- to west-facing aspects. Regardless of whether slopes are actively eroding, apparently the predominant condition as revealed in pedicelling and slope wash evidence, or are stabilized, they have a high degree of exposed soil and rock ( $80 \%$ or more combined cover). This community is found on drift mantled shales, mudstone, and siltstone. The vegetation composition and low cover values reflect the harsh nature of these sites. Muhlenbergia cuspidata is frequently the dominant graminoid though numerous instances of Bouteloua gracilis dominance were noted. Other high constancy, low cover graminoids adapted to these xeric, excessively-drained sites include Pseudoroegneria spicata (bluebunch wheatgrass), Hesperostipa comata (needle-and-thread), Calamagrostis montanensis (plains reedgrass), and Carex filifolia (threadleaved sedge). Either of the rhizomatous wheatgrasses (Pascopyrum smithii or Elymus lanceolatus, determination not possible) were consistently present with tillers widely spaced. Somewhat inexplicably Nassella viridula (green needlegrass) was noted frequently on these most moisture-stressed sites. The only forbs consistently noted are Lygodesmia juncea (rushlike skeletonweed), Pediomelum argophyllum (silverleaved scurfpea), Phlox hoodii (Hood's phlox), Penstemon (beardtongue) spp. and Sphaeralcea coccinea (scarlet globemallow). Combined shrub cover may exceed 5\% but individual cover does not; Artemisia filifolia (fringed sage), Gutierrezia sarothrae (broom snakeweed) and Artemisia cana (silver sagebrush) occur with consistency.

Comment: This association is quite similar in composition and landscape position to Muhlenbergia cuspidata - Schizachyrium scoparium of the Yellow Water Triangle (Jorgensen1979) and Pseudoroegneria spicata - Bouteloua gracilis of western Montana and beyond (Mueggler and Stewart 1980) and Pseudoroegneria spicata / Carex filifolia and Pseudoroegneria spicata - Bouteloua curtipendula of greater southeastern Montana and adjacent states. It is somewhat puzzling that Schizachyrium scoparium was not found consistently within this community, because this species is found distributed throughout the area and is well known to be associated with erodible substrates (White 1971). Pseudoroegneria's relative lack of importance may relate to excessive erosion. With more inventory across eastern Montana counties the essential equivalence of some of the above types may be established and their merger will follow. 


\section{Element Sources}

Author(s): Cooper, S. V. and C. Jean, MTNHP Confidence: 3

References: Cooper et al. 2001

\section{Pascopyrum smithii - Bouteloua gracilis Northern Plains Herbaceous Vegetation}

Western Wheatgrass - Blue Grama Herbaceous Vegetation

Global Rank: G? State Rank: S?

Element Code (state provisional): CEGLMTHP64

\section{Element Concept}

Summary: The western wheatgrass - blue grama Herbaceous Vegetation is provisionally identified as a northern Great Plains plant association of hot alluvial settings and thin soil settings overlying shale that are saturated in spring but dry for most of the growing season. It was also found at toeslope and footslope positions that presumably dry quickly following a saturated spring condition. It corresponds with the Bouteloua-Agropyron Faciation of Coupland (1960). Western wheatgrass comprises at least $20 \%$ cover and blue grama cover can be as much as twice that of western wheatgrass cover. Species diversity is low, and the characteristic forbs include Opuntia polyacantha (plains pricklypear), Linum rigidum (yellow flax), Hedeoma hispida (pennyroyal) and Sphaeralcea coccinea (scarlet globemallow). The subshrubs Gutierrezia sarothrae (broom snakeweed) and Artemisia frigida (fringed sage) are consistently present with low cover $(<5 \%)$ and a somewhat depauperate form of Artemisia cana (silver sagebrush) is also occurs scattered at low densities.

This association was noted to be common in northern Valley County in valleybottom settings of Buggy, South Fork Rock Creek, Crow Creek; presumably it is comparably distributed in drainages of other study area creeks. Heidel et al. (2000), first documented this association for Sheridan County; examples were documented in valleybottom settings along the Big Muddy Creek and in small areas of Sand Creek. It was also found to be locally common on the rolling uplands above alkali lakes. Though the latter is an upland setting, the soils are Ustifluvents.

Classification comments: There is also a Pascopyrum smithii-Bouteloua gracilis plant association recognized from foothill and lower-montane valleys of southwestern states. The northern Great Plains examples are treated separately because of non-overlapping climate and setting. However, intervening examples and additional vegetation comparison may link these plant associations that are provisionally treated as distinct. The Pascopyrum smithii - Bouteloua gracilis Northern Plains Herbaceous Vegetation plant association grades into the Pascopyrum smithii - Distichlis spicata plant association with an increase in salinity (and flooding). It grades into the Pascopyrum smithii or Pascopyrum smithii-

(Carex duriuscula) plant associations on sites experiencing intermittent flooding or that are subirrigated early in the growing season. This plant association is typical of the clayey range site. Additional vegetation sampling is needed to document and describe it.

\section{Element Sources}

Author(s): Cooper, S. V., C. Jean \& B. Heidel, MTNHP Confidence: 3

References: Cooper et al. 2001 
Pascopyrum smithii - (Carex duriuscula) Herbaceous Vegetation

Western Wheatgrass - (Needleleaf Sedge) Herbaceous Vegetation

Global Rank: G? State Rank: S?

Element Code: CEGLMTHP61

\section{Element Concept}

Summary: This small patch association was sampled and observed numerous times within a two county area in north-central Montana. This community is associated with shallow depressions that in "normal" years probably have standing water for a few days to a month or more at the beginning of the growing season, i. e. they are seasonally flooded (Cowardin et al. 1979). This type usually constitutes an encircling, though often discontinuous, vegetation band about these depression and ponds. The dominant visual aspect of a dense rhizomatous grassland is contributed by Pascopyrum smithii (western wheatgrass) with a lower layer of much more discontinuous coverage of Carex duriuscula (needleleaf sedge).

Environment: This association characteristically occurs in deeper swales and as one of mostly concentric zones around prairie potholes; it was noted only infrequently to be associated with the riparian zone. Because the bulk of these sites were surveyed in the droughty year of 2000 there was no standing water at the time of visitation (even the depression centers often were not flooded) and thus the water regime was difficult to determine. However, old wrack lines and silt deposits were sometimes noted, indicating that flooding had occurred. The soils most often were silt loams, silts, and silty clays. The next wetter zone often is occupied by following herbaceous wetland types, Pascopyrum smithiiEleocharis spp., Eleocharis palustris or Eleocharis acicularis. Drier positions on this gradient are often characterized as true upland sites with Elymus lanceolatus - Nassella viridula (or Pascopyrum smithii - Nassella viridula) and Elymus lanceolatus - Hesperostipa comata being the dominant vegetation types.

Vegetation: The vegetation is generally species poor, consisting of a thick sward of Pascopyrum smithii with a highly variable cover of Carex duriuscula. We noted that cattle appeared to preferentially graze the Carex duriuscula, even with healthy Pascopyrum smithii present. Occasionally these sites had scattered Distichlis stricta and Hordeum jubatum. The most constant forb was Aster falcatus.

Comments: There is a Pascopyrum smithii Habitat Type described by Hansen et al. (1995) for Montana that apparently occurs throughout the Intermountain West but neither their description nor their constancy-cover tables allude to the vegetation condition we have encountered in Valley and Phillips Counties. That is, none of these studies describe a co-dominance by Carex duriuscula and it is unclear just what landscapes they sampled to arrive at their classification but clearly the Pascopyrum smithii plant association from Idaho, Utah, and Washington would not have a Great Plains floristic component as does Pascopyrum smithii-Carex duriuscula.

\section{Element Sources}

Author(s): Cooper, S. V. and C. Jean, MTNHP Confidence: 3

References: Cooper et al. 2001, Hansen et al. (1995) 
Pascopyrum smithii - Distichlis spicata Herbaceous Vegetation

Western Wheatgrass - Inland Saltgrass Herbaceous Vegetation

Global Rank: G4 State Rank: S3S4

Element Code: CEGL001580

\section{Element Concept}

Summary: The Pascopyrum smithii - Distichlis spicata association has been described for mainly unglaciated landscapes in Wyoming, North Dakota and Nebraska where it is found typically in depressions and on steam terraces on deep, moderately saline soils. It is also present in the alkali lake systems of the prairie pothole region. It can be considered a wetland type when it occurs on soils that are saturated for part of the year and may flood periodically. This community is graminoid dominated with Pascopyrum smithii usually the more abundant of the two diagnostic grasses. Forbs seldom exceed 5\% canopy cover in the aggregate with the most constant being Aster falcatus (white-prairie aster), Plantago patagonica (Indian-wheat), Iva axillaris, and Helianthus petiolaris (prairie sunflower). Woody species constitute a very minor component, the most characteristic being Gutierrezia sarothrae (broom snakeweed) and Artemisia cana (silver sagebrush).

Within the $\mathrm{BCFC}$ area this association was most frequently associated with glacial depressions and stream terraces on soils of silty clay or clay loams. It was also found as very small pockets in saltaffected glacial outwash in what were hypothesized to be upland sites, though soils and hydrology information was lacking. In depression sites this association occurs on positions slightly drier than typified by the Pascopyrum smithii - Eleocharis spp. association. Salt efflorescence is occasionally visible in the stream terrace sites.

\section{Element Sources}

Authors: J. Drake, mod. D. Faber-Langendoen, WCS Confidence: 2

References: Hanson and Whitman 1938, Harner-White Consultants n.d., Hirsch 1985, Johnston 1987, Jones 1992, NVS Corporation n.d., Steinauer and Rolfsmeier 1997, Stoecker-Keammerer Consultants n.d. (a), Stoecker-Keammerer Consultants n.d.(a), Western Resources Development Corporation n.d., Western Resources Development Corporation n.d. (b)

Pascopyrum smithii - Eleocharis spp. Herbaceous Vegetation

Western Wheatgrass - Spikerush species Herbaceous Vegetation Global Rank: G1 State Rank: S1?

Element Code: CEGL001581

\section{Element Concept}

Summary: This association includes stands of herbaceous vegetation growing in periodically inundated, small playas on the northern Great Plains. The sites supporting this association are closed basins (playas) of $<1$ ha with fine-textured soils that impede drainage; consequently the playas are flooded periodically. The small basins supporting this association have standing water during "the wet seasons," presumably meaning mainly in the spring and also after heavy summer rains. Pascopyrum smithii and Eleocharis spp. (Eleocharis acicularis or Eleocharis palustris or both) dominate the vegetation, and Hordeum brachyantherum, Juncus balticus, and Alopecurus spp. often are present. Stands of this type typically include two zones, resulting from differences in the period of inundation. The lowest part of the stand, which is inundated most often and for the longest time, is dominated by 
Eleocharis acicularis, and may contain Hordeum brachyantherum, Juncus balticus, and Alopecurus aequalis or Alopecurus carolinianus, and bare soil accounts for about $75 \%$ of the ground surface; the higher part of the stand is dominated by Pascopyrum smithii and may contain substantial amounts of Carex douglasii and Vulpia octoflora var. octoflora (=Festuca octoflora). The species common in the surrounding vegetation are absent from stands of this type, or contribute little cover.

Vegetation: This type includes low herbaceous vegetation growing in closed basins. Pascopyrum smithii and Eleocharis acicularis generally dominate, and the plants common in the surrounding steppe generally are absent or contribute very little cover. Stands of this type typically include two zones, resulting from differences in the period of inundation. The following information is from two stands surveyed by Jones (1997): the lowest part of the stand, which is inundated most often and for the longest time, is dominated by Eleocharis acicularis and may contain Hordeum brachyantherum, Juncus balticus, and Alopecurus aequalis or Alopecurus carolinianus, and bare soil accounts for about $75 \%$ of the ground surface; the higher part of the stand is dominated by Pascopyrum smithii and may contain substantial amounts of Carex douglasii and Vulpia octoflora (= Festuca octoflora). According to Thilenius et al. (1995), Hordeum jubatum occurs on the margins of the stands.

Similar Associations: Pascopyrum smithii - Hordeum jubatum Herbaceous Vegetation (CEGL001582) — stands are dominated or co-dominated by Pascopyrum smithii, but Eleocharis acicularis is absent and Hordeum jubatum is a major species. Stands occur in playas where the subsoils contain higher concentrations of sodium (Paris and Paris 1974, Bergman and Marcus 1976). Holpp (1977) described vegetation from 10 playas in Campbell County, Wyoming that seem very similar to the playas containing this association. His stands generally were dominated by Pascopyrum smithii and contained some wetland species (Juncus balticus, Alopecurus carolinianus), but they showed no consistency in species composition and none contained Eleocharis acicularis.

Synonymy: Clayey overflow range site (Soil Conservation Service 1986) B. Stands of this association occur on the clayey overflow range site.

Agropyron smithii - Carex filifolia habitat type (Hansen et al. 1984) B. Hansen and Hoffman (1988) apparently include two stands of this association in their Agropyron smithii / Carex filifolia habitat type (Table A-5, pp. 42-43, stands 61 and 136) that contain only Pascopyrum smithii, Eleocharis acicularis, and Hordeum jubatum.

Agropyron smithii concentrations of sodium (Thilenius et al. 1995) B. The description of the Agropyron smithii sodgrass steppe (Thilenius et al. 1995) suggests that it is the same association, but the summary table, which shows low constancy of Eleocharis and high constancy or coverage of Poa secunda, Hesperostipa comata, and Koeleria macrantha, suggests that Thilenius et al. (1995) included vegetation on drier sites in their sodgrass steppe type.

Agropyron smithii - Eleocharis acicularis vegetation type (Bergman and Marcus 1976) =. See also U74PAR01MTUS (Paris and Paris 1974); their stands (Table E-6, pp. IX-E-18 \& 19) included Carex eleocharis.

Playa $($ Holpp 1977) $=$. Holpp described vegetation from 10 playas in Campbell County, Wyoming, that seem very similar to the playas containing this association. His stands generally were dominated by Pascopyrum smithii and contained some wetland species (Juncus balticus, Alopecurus carolinianus), but they showed no consistency in species composition and none contained Eleocharis acicularis.

GRank \& Reasons: G1 (98-11-30).

This association has been described from a small area (about 250 square miles) in northeastern Wyoming, mainly on the divide between the Belle Fourche River drainage and the Cheyenne River drainage. The range of the type extends into eastern Montana and may extend into western South Dakota, 
but further inventory and classification work are needed to confirm this. The area covered by stands of this association is estimated to be $<100$ acres because the playas are each 2 acres or smaller, and less than 50 occur in northeastern Wyoming where the association is best known. Enough additional stands may exist in other Northern Great Plains states (eastern Montana and the western Dakotas) to increase the estimated area to 100-1000 acres. The rank has been changed from G2G3 to G1 to reflect the very limited known distribution, the small number of stands, and the small proportion of stands that are undisturbed.

Comments: Species composition varies among stands of this type depending on the degree of inundation, but the degree of variation is unknown. More stand data might indicate that this association and Pascopyrum smithii - Hordeum jubatum Herbaceous Vegetation (CEGL001582) should be combined as it also occupies small playas.

\section{Element Distribution}

Range: This association has been described from a small area (ca. 250 square miles) in northeastern Wyoming, mainly on the divide between the Belle Fourche River drainage and the Cheyenne River drainage. Two stands apparently have been described from the area of the Montana - South Dakota border as well (Hansen and Hoffman 1988, Table A-5, stands 61 and 136), suggesting that the range of the type may extend into southeastern Montana and western South Dakota. It has been confirmed from northcentral Montana, just south of the Saskatchewan border.

States/Provinces: MT:S1?, SD:S?, SK:S? WY:S1

\section{Element Sources}

\section{Authors: G.P. Jones, WCS Confidence: 2}

References: Bergman and Marcus 1976, Bureau of Land Management 1979, Caballo Rojo Mine Application n.d., Hansen and Hoffman 1988, Hansen et al. 1984, Holpp 1977, Jones 1997, Mine Reclamation Consultants 1977, Paris and Paris 1974, Soil Conservation Service 1986, Thilenius et al. 1995, Western Resources Development Corporation n.d.

\section{Pascopyrum smithii - Nassella viridula Herbaceous Vegetation}

Western wheatgrass - Green needlegrass Herbaceous Vegetation

Global Rank: G4 State Rank: S4

Element Code: CEGL001583

\section{Element Concept}

Summary: This association is widespread across most of the northern Great Plains. Stands occur in narrow valleys, stream terraces, and on some upland positions (Jones 1992, USFS 1992). Soils are generally fine-textured, including clays, silts, silty clays, clay loams, or more unusually loams, and are moderately drained. The soil profile is typically well developed. Parent materials usually are siltstone and mixed sedimentary rock (USFS 1992). This association conventionally occurs on level or near level terrain but sometimes may occur on moderate slopes of all aspects. Most of the documentation of this association comes from unglaciated landscapes; its distribution and environmental parameters in glaciated settings need more work.

In the BCFC area this type was documented from several of the landscapes, usually in valleybottom settings representing highly productive "overflow" range sites. Pascopyrum smithii (western wheatgrass) is the dominant herb, often approaching a sward-like development. The cover for the diagnostic 
species Nassella viridula (green needlegrass) is highly variable, depending perhaps on past or ongoing grazing regimes. If this species had at least 3\% canopy cover we interpreted this to be a significant amount denoting the presence of this association.

\section{Element Distribution}

Range: This western wheatgrass - needlegrass community is common across much of the northern Great Plains of the United States and possibly Canada, ranging from Colorado and possibly Nebraska, north to Montana and North Dakota, and possibly Saskatchewan.

States/Provinces: CO?, MT:S4, ND:S3?, NE?, SD:S4, SK?, WY:S3?

\section{Element Sources}

Authors: K.J. Hirsch, mod. J. Drake and D. Faber-Langendoen, WCS Confidence: 1 Identifier: CEGL001583

References: Bear Creek Uranium Mine Application n.d., DeVelice et al. 1991, Hirsch 1985, Johnston 1987, Jones 1992, Redmann 1975, Stoecker-Keammerer Consultants n.d., U.S. Forest Service (USFS)

1992, Western Resources Development Corporation n.d. (a)

Populus deltoides / Symphoricarpos occidentalis Woodland

Plains Cottonwood / Western Snowberry Woodland

Global Rank: G2G3 State Rank: S3

Element Code: CEGL000660

\section{Element Concept}

Summary: This riparian woodland community is found in the northwestern Great Plains of the United States on medium to coarse-textured alluvial soils on the floodplains of major rivers. The floodplains are both seasonally inundated and subirrigated. It is found more rarely at higher elevations in the mountains of eastern Wyoming and western South Dakota. This community is dominated by a single deciduous tree species, Populus deltoides. In some stands other species, such as Acer negundo (box elder) and Fraxinus pennsylvanica (green ash), may contribute to the canopy. The tallest trees exceed 15 meters. The shrub layer is typically 0.5-1 m tall. It is dominated by Symphoricarpos occidentalis and commonly includes Juniperus scopulorum (Rocky Mountain juniper) and Rosa (rose) spp. In Wyoming, Ericameria nauseosa (= Chrysothamnus nauseosus, common rabbitbrush) is present and increases with heavy grazing. The herbaceous layer usually includes Pascopyrum smithii (western wheatgrass). Weedy species such as Melilotus officinalis (yellow sweet clover), Taraxacum officinale (common dandylion), and Poa secunda (Sandberg's bluegrass) are very common, especially in the presence of grazing. Maianthemum stellatum (starry Solomon's seal) is abundant only where grazing is absent.

Environment: This community is found on medium to coarse-textured alluvial soils on the floodplains of major rivers. The floodplains are both seasonally inundated and subirrigated (Thilenius et al. 1995). The meandering erosional and depositional pattern of rivers maintains and influences this community along rivers (Hanson 1990). It is rarely found at higher elevations in the mountains of eastern Wyoming and western South Dakota (Johnston 1987).

Vegetation: This community is typically dominated by a single deciduous tree species, Populus deltoides. In some stands other species, such as Acer negundo and Fraxinus pennsylvanica, may contribute to the canopy. The tallest trees exceed 15 meters. Populus deltoides is a pioneer species that 
requires moist, sparsely vegetated alluvium to become established from seed; therefore stands of this community may be considered seral, but the stage is long persistent (up to 100 years) (Girard et al. 1989). The shrub layer is typically 0.5-1 $\mathrm{m}$ tall. It is dominated by Symphoricarpos occidentalis and commonly includes Juniperus scopulorum and Rosa spp. In Wyoming, Ericameria nauseosa is present and increases with heavy grazing (Thilenius et al. 1995). The herbaceous layer usually includes Pascopyrum smithii and Elymus trachycaulus. Weedy or increaser species such as Cirsium arvense, Melilotus officinalis, Taraxacum officinale, Bromus inermis (smooth brome), Poa pratensis (Kentucky bluegrass), Agropyron repens (quackgrass) and Poa secunda are very common, especially in the presence of grazing (Jones and Walford 1995, Thilenius et al. 1995). Maianthemum stellatum is abundant only where grazing is absent.

Dynamics: This type is found closest to the river on young, unstabilized floodplains, where it colonizes the freshly deposited alluvial substrates on the meanders of the streams and rivers. From extreme eastern Montana and further eastward the following successional model is operative: Proceeding away from the river, later successional stages may include a Populus deltoides - Fraxinus pennsylvanica community type (CEGL000658) and a Fraxinus pennsylvanica - (Ulmus americana) / Symphoricarpos occidentalis Forest (CEGL002088). As the stream continues to move away from the more recent deposits, the stand may eventually succeed to the Fraxinus pennsylvanica type, a process that could take 100 years (Girard et al. 1989). Within the Bitter Creek / Frenchman Creek study west of the distribution of Fraxinus pennsylvanica and Ulmus americana (American elm) these Populus deltoides stands do not succeed to the these more shade tolerant trees. Rather, the Populus deltoides component tends to slowly die out until a Symphoricarpos occidentalis-dominated stand is the consequence.

Comments: Concept of the type may have come from Thilenius and Smith (1990). In eastern Montana, Hanson et al. $(1990,1995)$ describe a Populus deltoides / Symphoricarpos occidentalis type as a grazing-induced stage of the Populus deltoides / Cornus sericea type. This contrasts with information from Wyoming, where Thilenius et al. (1995) found that Symphoricarpos occidentalis decreases with grazing and Ericameria nauseosa (=Chrysothamnus nauseosus) increases.

\section{Element Distribution}

Range: This riparian woodland community is found in floodplains of the northwestern Great Plains of the United States, ranging from eastern Montana to North Dakota and south to Colorado.

States/Provinces: CO:S2, MT:S3, ND:S1S2?, SD?, WY:S2

\section{Element Sources}

Author(s): Drake, J., MWCS; modified Cooper, S.V. and C. Jean, MTNHP Confidence: 1

References: Girard et al. 1989, Hansen et al. 1990, Hansen et al. 1995, Johnson et al. 1990a, Johnston 1987, Jones and Walford 1995, Kartesz 1999, Kittel et al. 1999, Thilenius 1970, Thilenius and Brown 1990, Thilenius and Smith 1985, Thilenius et al. 1995 
Prunus virginiana - (Prunus americana) Shrubland

Common Chokecherry - (American Plum) Shrubland

Global Rank: G4Q State Rank: S4?

Element Code: CEGL001108

\section{Element Concept}

Summary: This community has a wide distribution, being reported from states primarily in the northwestern United States, including the northwestern Great Plains, but also in Nevada. In Colorado, this riparian shrubland occurs as small pockets on higher terraces or as narrow bands along the highwater mark of steep banks and incised channels. It can also grow at the base of cliffs adjacent to rivers and streams where it forms impenetrable thickets. Stands have a dense, medium-tall (1.5-2 m) shrub canopy that is almost impossible to walk through. This vegetation is dominated by Prunus virginiana and grows at the interface between the riparian areas and the adjacent upland. Shrub cover is generally greater in drainage bottoms and on lowermost slopes, and less on slopes. Prunus virginiana may be the dominant shrub species, but often other species are codominant or dominant, especially on slopes, including Rhus trilobata (skunkbush sumac), Amorpha canescens (lead plant), Symphoricarpos occidentalis (western snowberry) and Toxicodendron pubescens (poison ivy). Stands dominated by Prunus americana may be a variant of this type. In drainage bottom situations, herbaceous cover is usually sparse, less than $10 \%$. On slopes, the shrubs typically occur in some grassland type, and graminoid cover can be greater than $75 \%$.

Environment: In Colorado, this association grows at the interface between the riparian areas and the adjacent upland. Stands usually occur as small pockets on higher terraces or as narrow bands along the high water mark of steep banks and incised channels. It can also grow at the base of cliffs adjacent to rivers and streams where it forms impenetrable thickets (Colorado NHP pers. comm. 1998). In southwestern South Dakota, stands are found in a variety of habitats. Slope varies from flat to very steep, with variable aspect. Stands are commonly found in the bottoms of draws and drainages. This type also occurs associated with rock outcrops (H. Marriott pers. comm. 1999, Von Loh et al. 1999).

Vegetation: In Colorado, this community type is a medium-height (1.5-2 m) shrubland with dense vegetation that is almost impossible to walk through. (Colorado NHP pers. comm., 1998). In southwestern South Dakota, this type is characterized by moderate to dense shrub cover, typically in the 25$75 \%$ range. Shrub cover is generally greater in drainage bottoms and on lowermost slopes, and less on slopes. Prunus virginiana may be the dominant shrub species, but often other species are codominant or dominant, especially on slopes, including Prunus americana, Rhus trilobata, Amorpha canescens, Symphoricarpos occidentalis and Toxicodendron pubescens. In drainage bottom situations, herbaceous cover is usually sparse, less than $10 \%$. On slopes, the shrubs typically occur in some grassland type, and graminoid cover can be greater than $75 \%$.

Study Area Comments: Within the project area this association occurs as very small patches, often linear, of dense (nearly impenetrable) Prunus stems. These patches occur at the heads of coulees feeding into the Bitter Creek Badlands or toeslope and drainage bottom positions within these same coulees; almost certainly other habitat favorable for this association exists throughout this landscape but the type was not recorded. Prunus has been severely hedged by browsing ungulates. Heidel et al. (2000), also noted intensely browsed stands in the Medicine Lake vicinity of Sheridan County. The undergrowth is very depauperate obstenibly due to the density of the Prunus canopy; Symphoricarpos occidentalis, Rosa arkansana, Shepherdia argentea, and Ribes spp. were noted to be consistently associated with this community, usually at the periphery of the patches. How these sites differ from those supporting the Shepherdia argentea (thorny buffaloberry) association, other than the dominant shrub, is not obvious. Though Hansen et al. (1995) consider this a grazing disclimax (of Fraxinus 
pennsylvanica (green ash) and Acer negundo (box elder)), we saw no evidence that these trees had, or would, necessarily occupy these sites within the project area. The paucity of seed sources for these trees also renders this point moot.

Dynamics: Hansen et al. (1995), consider the stands in central and eastern Montana to be grazing (browsing) disclimax, potentially climax in Fraxinus pennsylvanica or Acer negundo. Some stands on slopes are the result of recent fire that killed the overlying canopy, converting a Pinus ponderosa / Prunus virginiana Forest (CEGL000192) to this Prunus virginiana shrubland type.

\section{Element Distribution}

Range: This association has a wide distribution, reported chiefly from the northwestern United States, including the northwestern Great Plains, with an outlier in Nevada.

\section{Element Sources}

Authors: D. Faber-Langendoen, WCS Confidence: 2

References: Caicco and Wellner 1983n, Copeland 1980a, Evans 1989a, Hansen et al. 1991, Hansen et al. 1995, Jones and Walford 1995, Kittel et al. 1996, Kittel et al. 1999, Von Loh et al. 1999

Rhus trilobata / Elymus lanceolatus - Nassella viridula Shrub Herbaceous

Skunkbush Sumac / Thickspike Wheatgrass - Green Needlegrass

Global Rank: G? State Rank: S2S3?

Element Code: CEGLMTHP55

\section{Element Concept}

Summary: This provisional association is documented by only two plots, both occurring in the Frenchman Creek breaklands, but it has been observed on other locations within greater northeastern Montana. It is found as small patches, chiefly occurring in linear forms along the convex shoulders and short slopes that descend form the sedimentary benchlands or terraces above the ephemeral tributaries of the Frenchman and Rock Creeks. Slope aspect ranged from northwest to east. Soils are typically developed from sandstone or sandstones mixed with finer textured materials. Some stem pedicelling is evident and the percentage of exposed soil surface is usually in excess of $60 \%$, suggesting sheet erosion to be common. Rhus trilobata (skunkbush sumac) is generally the dominant shrub with $15 \%$ or higher cover but, Juniperus horizontalis (creeping juniper) may exhibit comparably high coverages. A number of other shrub species, generally associated with mesic sites including Prunus virginiana (common chokecherry), Symphoricarpos occidentalis (western snowberry), Artemisia cana (silver sagebrush) and Shepherdia argentea (thorny buffaloberry) are variously present with low canopy cover values. The graminoid component is diverse in both species number and their indicator values; dominance is shared between varying combinations of Elymus lanceolatus (thickspike wheatgrass) and Elymus trachycaulus (bearded wheatgrass) whose combined cover is generally in excess of $40 \%$. Other important graminoids include those expected for erosive, coarse-textured soils, such a Hesperostipa comata (needle-and-thread), Muhlenbergia cuspidata (plains muhly), and Calamagrostis montanensis (plains reedgrass) as well as Nassella viridula (green needlegrass), which generally reflects mesic habitats. Forbs occur in trace amounts; Ratibida columnifera (prairie coneflower) was the only one present on all sites. 
Comments: This provisional plant association has not been previously described, but it bears a similarity, in both its position in the landscape and to a limited degree in its composition, to Rhus trilobata / Festuca idahoensis (skunkbush sumac / Idaho fescue, which occurs at the western margin of the Great Plains).

\section{Element Sources}

Authors: S.V. Cooper Confidence: 3

References: Cooper et al. 2001, Culwell and Scow 1982

\section{Rhus trilobata / Schizachyrium scoparium Shrub Herbaceous Vegetation}

Skunkbush Sumac / Bluebunch Wheatgrass

Global Rank: G3? State Rank: S3?

Element Code: CEGL001506

\section{Element Concept}

Environment: Rhus trilobata / Schizachyrium scoparium is a minor type described only for eastern Montana landscapes, occurring as small patches on gently to steeply sloping breaklands, mostly on slope shoulders but capable of extending to footslopes. Exposures are generally the warmest in a local mosaic. Substrates included calcareous sandstones and shales and a lone instance on an extrusive volcanic; all soils are shallow and coarse-textured. Surface coverage varied between high coverages of soil/gravel (>50\%) and swards of Selaginellla densa (compact clubmoss, on overgrazed land). Adjacent community types are often of the Artemisia tridentata series or Hesperostipa comata - Bouteloua gracilis (needle-and-thread - blue grama grass, on uplands).

Vegetation: Well-represented Rhus trilobata is diagnostic for the type; coverage ranges to $20 \%$. Other shrubs include Artemisia frigida (fringed sage), Gutierrezia sarothrae (broom snakeweed) and Yucca glauca (yucca). Schizachyrium scoparium (blue grama) and usually Pseudoroegneria spicata (bluebunch wheatgrass) are well represented, but due to site severity (and grazing), they do not exhibit high cover values. Hesperostipa comata (needle-and-thread) and Muhlenbergia cuspidata (plains muhly) have $100 \%$ constancy and Hesperostipa comata tends to have relatively higher coverage on accessible sites with grazing pressure; rhizomes of Pascopyrum smithii (western wheatgrass) ramify throughout the stands but with few tillers. Phlox hoodii (Hood's phlox) and Liatris punctata (blazingstar) were present in all plots.

Study Area Comments: Within the Bitter / Frenchman Creek study area Yucca glauca was not encountered and Pseudoroegneria spicata was a very minor associate. Culwell and Scow (1982) first described this type in the vicinity of Roundup, MT. Brown (1971) described this, or a similar type, for slope shoulders in southeastern MT badlands (porcellanite substrates). Mueggler and Stewart (1980) described a Rhus trilobata / Pseudoroegneria spicata association, a close analogue of Rhus trilobata / Schizachyrium scoparium, from the breaklands of the Missouri River's major tributaries, especially in the vicinity of the Yellowstone River drainage; though floristic composition differs slightly, their type is essentially the same in landscape position and environmental variables as described herein. Hansen and Hoffman (1988) extended the known distribution of Mueggler and Stewart's Rhus trilobata / Pseudoroegneria spicata type and referenced it as having appreciable Schizachyrium scoparium, especially in early seral conditions. 


\section{Element Sources}

Authors: S.V. Cooper Confidence: 3

References: Cooper et al. 2001, Culwell and Scow 1982

Spartina pectinata Western Herbaceous Vegetation

Prairie Cordgrass Western Herbaceous Vegetation

Global Rank: G3? State Rank: S3?

Element Code: CEGL001476

\section{Element Concept}

Summary: This is a small patch, tallgrass meadow comprised entirely of Spartina pectinata. Stands occur in small swales on the plains as well as on floodplains of larger rivers. Stands of this grass have been included in other tallgrass prairie plant associations. On large river floodplains, this type occurs as distinct patches and is distinguished from adjacent riparian types by micro-topography and degree of soil saturation. Weaver (1965) reports that historically, large stands of Spartina pectinata occurred on mud flats of the Missouri River. Large stands have been observed south of Denver, now threatened by housing and golf course developments (Steve Kettler pers. comm.).

\section{Similar Associations:}

Spartina pectinata - Carex spp. Herbaceous Vegetation (CEGL001477)

\section{Synonymy:}

Spartina pectinata Dominance Type (Evans 1989a) =. (p.32)

GRank \& Reasons: G3? (96-02-01).

Comments: Compare this association with Spartina pectinata - Carex spp. Herbaceous Vegetation (CEGL001477).

\section{Element Distribution}

States/Provinces: CO:S1, MT:S3?, WA:S1, WY:S?

\section{Element Sources}

Authors: WCS Confidence: 2 Identifier: CEGL001476

References: Evans 1989a, Hansen and Hoffman 1988, Hansen et al. 1989, Hansen et al. 1991, Hansen et al. 1995, Kittel et al. 1996, Weaver 1965

\section{Shepherdia argentea Shrubland}

Thorny buffaloberry Shrubland

Global rank: G3G4 State rank: S3?

Element Code: CEGL001128

\section{Element Concept}

Summary: The thorny buffaloberry shrubland is a mesic shrubland plant association found in the northern Great Plains from North Dakota and Saskatchewan to Colorado occurring on stream terraces, 
rolling uplands, and badlands. It is found where moisture is more plentiful than on the surrounding landscape, such as in swales, ravines, near streams, and on northwest- to east-facing slopes. This plant association is dominated by a moderate to dense canopy of medium-tall shrubs. The most abundant of these and diagnostic for the vegetation type, Shepherdia argentea, is typically $1.5-3 \mathrm{~m}$ tall. Other common shrub species are Prunus virginiana (common chokecherry), Rhus trilobata (skunkbush sumac), Rosa woodsii (Wood's rose), and Symphoricarpos occidentalis (western snowberry). Graminoids and forbs may have only half the coverage of the shrub layer. Predictably present graminoids include Pascopyrum smithii (western wheatgrass) and invasion by Poa pratensis (Kentucky bluegrass). Common forbs are Achillea millefolium (yarrow), Artemisia ludoviciana (prairie sagewort), Geum triflorum (prairie smoke) and Parietaria pennsylvanica (common pellitory).

Environment: This community is found on stream terraces, rolling uplands, and badlands. It occurs where moisture is more plentiful than on the surrounding landscape, such as in swales, ravines, near streams, and on northwest- to east-facing slopes (Hansen and Hoffman 1988, DeVelice et al. 1995). This trend is more pronounced in Wyoming where Jones and Walford (1995) only found this community near streams, and it may be less pronounced in Saskatchewan and northern Montana. Soils are loamy sand, sandy loam, silty loam, or loam and are derived from glacial drift, siltstone, or sandstone (USFS 1992, DeVelice et al. 1995). This community does not flood often, but some sites show evidence of a high water table (DeVelice et al. 1995).

Vegetation: The vegetation is dominated by a moderate to dense canopy of medium-tall shrubs. The most abundant of these, Shepherdia argentea, is typically 1.5-3 $\mathrm{m}$ tall. Other species commonly found in the shrub layer are Juniperus horizontalis, Prunus virginiana, Ribes spp., Rhus aromatica, Rosa woodsii, and Symphoricarpos occidentalis. Herbaceous species are not important in this community. Graminoids and forbs may have only half the coverage of the shrub layer (Hansen and Hoffman 1988, USFS 1992). Graminoids include Poa pratensis, Pascopyrum smithii, and Bromus spp. Common forbs are Achillea millefolium, Artemisia ludoviciana, and Parietaria pensylvanica. Litter may accumulate in this community (DeVelice et al. 1995).

Study Area Comments: The Shepherdia argentea plant association is uncommon within the study area as a whole, with the exception of the Bitter Creek Badlands where the type occurred somewhat predictably on steep north slopes and highly protected positions at drainage heads. All study area observations were of small patch stands almost invariably less than an acre in size. A number of occurrences in the Bitter Creek vicinity occur as stingers in riparian settings (classified as seasonally flooded wetland by Thompson (1994)) as is more common for the type to the east in Roosevelt County. In a departure from the general conception of the type, study area stands consistently had 1) Ribes setosum (Missouri gooseberry) and Juniperus horizontalis (creeping juniper) present and often well represented in the shrub layer, 2) Nassella viridula (green needlegrass), Calamagrostis montanensis (prairie reedgrass), Koeleria macrantha (prairie junegrass), Galium boreale (northern bedstraw), Geum triflorum (prairie smoke) as consistently present, often well represented, herbaceous components. These moist sites, often with appreciable open ground have proved to be prime habitat for Euphorbia esula (leafy spurge), which is dispersed to the widely separated sites via bird droppings (mainly doves?). Cirsium arvense (Canada thistle), another noxious weed, was also observed on these sites and not in immediately adjacent terrain. The BLM has an aerial spraying program in effect for leafy spurge, unfortunately wind drift has caused inadvertent mortality in associated species, particularly the Shepherdia.

\section{Element Distribution}

Range: This mesic buffaloberry shrubland community is found in the northern Great Plains of the United States and Canada, extending from Colorado northward to the Dakotas and Saskatchewan. This 
mesic shrubland community is found in the northern Great Plains on stream terraces, rolling uplands, and badlands.

States/Provinces: CO:S1, MT:S3?, ND:S?, SD:S?, SK:S?, WY:S?

\section{Element Sources}

Authors: J. Drake, WCS; mod. S. V. Cooper \& C. Jean, MTNHP Confidence: 2

References: DeVelice et al. 1995, Cooper et al. 2001, Hansen et al. 1984, Hansen et al. 1991, Hansen et al. 1995, Jones and Walford 1995, Kittel and Lederer 1993, Kittel et al. 1994, Kittel et al. 1999, U.S. Forest Service (USFS) 1992

\section{Symphoricarpos occidentalis Shrubland}

Western Snowberry

Global Rank: G4G5 State Rank: S4S5

Element Code: CEGL001131

\section{Element Concepts}

Summary: The western snowberry shrubland is found as a small to large patch type in mesic depressions, swales, ravines and floodplains, typically surrounded by upland grassland associations and occasionally forming a mosaic with Artemisia cana-dominated polygons. The soils are silts, loams and sandy loams. Some stands are occasionally flooded whereas others are just very moist. Thus it tends to fall on both sides of the upland/wetland division. It has been classified in both temporarily and seasonally flooded wetland classes elsewhere in northeastern Montana, where it is among the most extensive of flooded wetland plant associations (Thompson 1994). This type has a shrub layer (app. $80 \mathrm{~cm}$ tall) with high canopy cover (averages $>50 \%$ ), sometimes with well-developed graminoid- and forb-layers. Symphoricarpos occidentalis is the predominant species in the shrub layer and at times forms almost monospecific stands. Rosa woodsii (Wood's rose) and sometimes Artemisia cana (silver sage) occur interspersed with the Symphoricarpos occidentalis. Stands that have not been excessively grazed may have a strong component of Pascopyrum smithii (western wheatgrass), Elymus lanceolatus (thickspike wheatgrass), Nassella viridula (green needlegrass) and Carex duriuscula (needle-leaved sedge); with increasing grazing pressure the Poa secunda (Sandberg's bluegrass) complex, Poa pratensis (Kentucky bluegrass) and annual grasses (especially Bromus japonicus (Japanese brome)) become more prevalent. The most commonly occurring forbs can be categorized as increasers with disturbance including Achillea millifolium (common yarrow), Melilotus officinalis (yellow sweetclover), Artemisia ludoviciana (prairie sagewort), Glycyrrhiza lepidota (American licorice).

This association is present throughout the study area, including shallow prairie potholes, valley margins, and widely scattered elsewhere. This type is often invaded and not infrequently dominated by Poa pratensis (Kentucky bluegrass); less often, at least within the study area, Bromus inermis (smooth brome) expands to dominate within the swale environments (attaining greater cover than Symphoricarpos occidentalis) and then is capable of expanding to upslope, drier habitats as well.

Comments: It corresponds with the Symphoricarpos occidentalis - Rosa woodsii association encroaching on sandhill flats and swales as described by Lesica (1987a) for Sheridan County. The same type was found in the Missouri Coteau prairie potholes in concave areas of lee slopes where snow accumulates (Lesica 1987b). Symphoricarpos occidentalis is also recognized as a major component of the mixed grass prairie region in Saskatchewan (Riparian and Wetland Research Program 2000). Hansen et al. (1995), view this community as purely a mid-seral disturbance type but don't indicate to what it will 
succeed. We view these as long-term stable sites, though with overgrazing the graminoid component will almost certainly be permanently altered.

\section{Element Sources}

Authors: Drake, J. F., WCS Confidence: 3

References: Christy 1973, Clark 1977b, Clark et al. 1980, Hansen et al. 1984, Hansen et al. 1991, Hansen et al. 1995, Johnston 1987, Jones 1992, Jones and Walford 1995, Kittel et al. 1994, Kittel et al. 1999, McAdams et al. 1998, Meyer 1985, Steinauer and Rolfsmeier 1997 


\section{Appendix D: Plant Community Summary Matrix}

Summary matrix of Plant Communities described from Bitter Creek - Frenchman Creek study area (arranged alphabeticallywithin lifeform; new vegetation types are distinguished by shading)

\begin{tabular}{|c|c|c|c|c|c|c|c|c|c|}
\hline Plant Associations (Scientific \& Common Name) & $\begin{array}{l}\text { Global } \\
\text { Rank }\end{array}$ & $\begin{array}{l}\text { State } \\
\text { Rank }\end{array}$ & 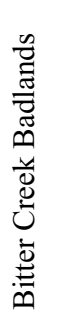 & 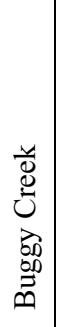 & 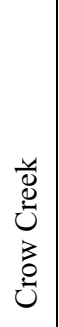 & 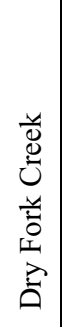 & 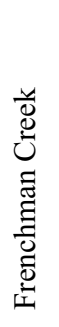 & 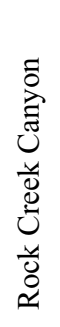 & 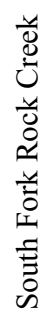 \\
\hline \multicolumn{10}{|l|}{ FORESTS / WOODLANDS } \\
\hline $\begin{array}{l}\text { Juniperus scopulorum / Piptatherum micranthum Woodland } \\
\text { (Rocky Mountain juniper / Small-seeded ricegrass) }\end{array}$ & G3G4 & S3 & & & & & & $\mathrm{x}$ & \\
\hline $\begin{array}{l}\text { Populus deltoides / Symphoricarpos occidentalis Woodland } \\
\text { (Plains cottonwood / Western snowberry) }\end{array}$ & G2G3 & S2S3 & & $\mathrm{x}$ & & & $\mathrm{x}$ & $\mathrm{x}$ & \\
\hline \multicolumn{10}{|l|}{$\begin{array}{l}\text { Populus tremuloides Alliance } \\
\text { (Trembling aspen Alliance) }\end{array}$} \\
\hline \multicolumn{10}{|c|}{ SHRUBLANDS (INCLUDING DWARF-SHRUBLANDS \& SHRUB HERBACEOUS) } \\
\hline $\begin{array}{l}\text { Artemisia cana / Elymus lanceolatus - (Nassella viridula) Shrub Herbaceous Vegetation } \\
\text { (Silver sagebrush / Thickspike wheatgrass - (Green needlegrass)) }\end{array}$ & G? & S3? & $\mathrm{x}$ & $\mathrm{x}$ & $\mathrm{x}$ & $\mathrm{x}$ & $\mathrm{x}$ & & \\
\hline $\begin{array}{l}\text { Artemisia cana / Pascopyrum smithii Shrubland } \\
\text { (Silver sagebrush / Western wheatgrass) }\end{array}$ & G4 & S4 & $\mathrm{x}$ & $\mathrm{x}$ & $\mathrm{x}$ & & $\mathrm{x}$ & $\mathrm{x}$ & $\mathrm{x}$ \\
\hline $\begin{array}{l}\text { Artemisia cana / Hesperostipa comata Shrub Herbaceous Vegetation } \\
\text { (Silver sagebrush / Needle-and-thread) }\end{array}$ & G3 & S3 & & & & & & $\mathrm{x}$ & \\
\hline $\begin{array}{l}\text { Atriplex gardneri / Endolepis dioica Dwarf-shrubland } \\
\text { (Gardner's saltsage / Rillscale) }\end{array}$ & G? & S2? & $\mathrm{x}$ & & & & & & $\mathrm{x}$ \\
\hline $\begin{array}{l}\text { Artemisia tridentata ssp. wyomingensis / Elymus lanceolatus ssp. albicans Shrubland } \\
\text { (Wyoming big sagebrush / Thickspike wheatgrass) }\end{array}$ & G4 & S4? & & & & & & & \\
\hline
\end{tabular}




\begin{tabular}{|c|c|c|c|c|c|c|c|c|c|}
\hline Plant Associations (Scientific \& Common Name) & $\begin{array}{l}\text { Global } \\
\text { Rank }\end{array}$ & $\begin{array}{l}\text { State } \\
\text { Rank }\end{array}$ & 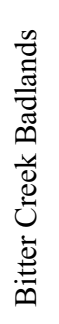 & 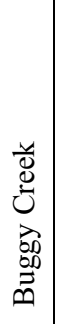 & 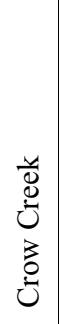 & 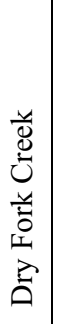 & 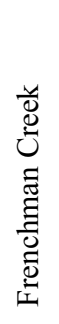 & 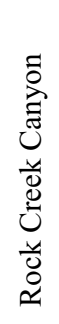 & 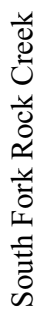 \\
\hline $\begin{array}{l}\text { Eriogonum pauciflorum - Gutierrezia sarothrae Badlands Sparse Vegetation } \\
\text { (Few-flowered wild buckwheat - Broom snakeweed) }\end{array}$ & G4G5 & S3S4? & $\mathrm{x}$ & & $\mathrm{x}$ & & & & $\mathrm{x}$ \\
\hline $\begin{array}{l}\text { Juniperus horizontalis / Calamovilfa longifolia Dwarf-shrubland } \\
\text { (Creeping juniper / Prairie sandreed) }\end{array}$ & G? & $\mathrm{S} 2 ?$ & $\mathrm{x}$ & & & & $\mathrm{x}$ & $\mathrm{x}$ & \\
\hline $\begin{array}{l}\text { Juniperus horizontalis / Elymus lanceolatus Dwarf-shrubland } \\
\text { (Creeping juniper /Thickspike wheatgrass) }\end{array}$ & G? & S3? & $\mathrm{x}$ & & $\mathrm{x}$ & & $\mathrm{x}$ & $\mathrm{x}$ & \\
\hline $\begin{array}{l}\text { Juniperus horizontalis / Elymus trachycaulus Dwarf-shrubland } \\
\text { (Creeping juniper / Bearded wheatgrass) }\end{array}$ & G? & S2S3? & $\mathrm{x}$ & & $\mathrm{x}$ & & $\mathrm{x}$ & & \\
\hline $\begin{array}{l}\text { Juniperus horizontalis / Juncus balticus Dwarf-shrubland } \\
\text { (Creeping juniper / Baltic rush) }\end{array}$ & G? & $\mathrm{S} 2 \mathrm{~S} 3 ?$ & $\mathrm{x}$ & & & & & & \\
\hline $\begin{array}{l}\text { Juniperus horizontalis / Schizachyrium scoparium Dwarf-shrubland } \\
\text { (Creeping juniper / Little bluestem) }\end{array}$ & G4 & S4 & $\mathrm{x}$ & & & & $\mathrm{x}$ & & \\
\hline $\begin{array}{l}\text { Juniperus horizontalis / Hesperostipa curtiseta - (Elymus lanceolatus) Dwarf-shrubland } \\
\text { (Creeping juniper / Northern porcupine grass - (Thickspike wheatgrass)) }\end{array}$ & G? & S3? & $\mathrm{x}$ & & & $\mathrm{x}$ & & & \\
\hline $\begin{array}{l}\text { Prunus virginiana - (Prunus americana) Shrubland } \\
\text { (Common chokecherry - (American plum)) }\end{array}$ & G4? & S4? & $\mathrm{x}$ & & & & & $\mathrm{x}$ & \\
\hline $\begin{array}{l}\text { Rhus trilobata / Elymus lanceolatus - Nassella viridula Shrub Herbaceous } \\
\text { (Skunkbush sumac / Thickspike wheatgrass - Green needlegrass) }\end{array}$ & G? & S2S3? & & & $\mathrm{x}$ & & $\mathrm{x}$ & & \\
\hline $\begin{array}{l}\text { Rhus trilobata / Schizachyrium scoparium Shrub Herbaceous } \\
\text { (Skunkbush sumac / Little bluestem) }\end{array}$ & G3? & S3? & & & & & $\mathrm{x}$ & $\mathrm{x}$ & \\
\hline $\begin{array}{l}\text { Salix exigua Temporarily Flooded Shrubland } \\
\text { (Coyote willow) }\end{array}$ & G5 & S5 & & $\mathrm{x}$ & & & $\mathrm{x}$ & & $\mathrm{x}$ \\
\hline $\begin{array}{l}\text { Sarcobatus vermiculatus / Pascopyrum smithii - (Elymus lanceolatus) Shrub Herbaceous } \\
\text { (Black greasewood / Western wheatgrass (Thickspike wheatgrass) }\end{array}$ & G4 & S4 & $\mathrm{x}$ & & & & & & \\
\hline
\end{tabular}




\begin{tabular}{|c|c|c|c|c|c|c|c|c|c|}
\hline Plant Associations (Scientific \& Common Name) & $\begin{array}{l}\text { Global } \\
\text { Rank }\end{array}$ & $\begin{array}{l}\text { State } \\
\text { Rank }\end{array}$ & 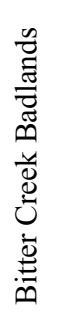 & 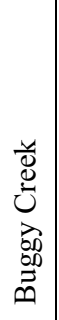 & 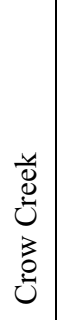 & 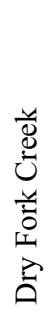 & 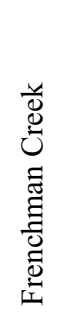 & 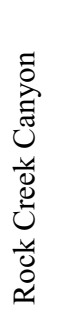 & 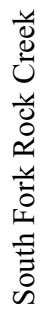 \\
\hline $\begin{array}{l}\text { Shepherdia argentea Shrubland } \\
\text { (Thorny buffaloberry) }\end{array}$ & G3G4 & S3? & $\mathrm{x}$ & & & & & $\mathrm{x}$ & \\
\hline $\begin{array}{l}\text { Symphoricarpos occidentalis Shrubland [Provisional] } \\
\text { (Western snowberry) }\end{array}$ & G4G5 & S4S5 & $\mathrm{x}$ & $\mathrm{x}$ & $\mathrm{x}$ & $\mathrm{x}$ & $\mathrm{x}$ & $\mathrm{x}$ & $\mathrm{x}$ \\
\hline \multicolumn{10}{|c|}{ HerbaCeous Vegetation } \\
\hline $\begin{array}{l}\text { Artemisia longifolia Badlands Sparse Vegetation } \\
\text { (Longleaf sagewort) }\end{array}$ & G? & $\mathrm{S} 2 \mathrm{~S} 3$ & $\mathrm{x}$ & & $\mathrm{x}$ & & & $\mathrm{x}$ & $\mathrm{x}$ \\
\hline $\begin{array}{l}\text { Calamagrostis montanensis Herbaceous Vegetation } \\
\text { (Plains reedgrass) }\end{array}$ & G? & S2S3? & & $\mathrm{x}$ & & & & & \\
\hline $\begin{array}{l}\text { Calamovilfa longifolia - Carex inops ssp. heliophila Herbaceous Vegetation } \\
\text { (Prairie sandreed - Sun sedge) }\end{array}$ & G3 & S3? & $\mathrm{x}$ & $\mathrm{x}$ & & & & $\mathrm{x}$ & \\
\hline $\begin{array}{l}\text { Calamovilfa longifolia - Hesperostipa comata Herbaceous Vegetation } \\
\text { (Prairie sandreed - Needle-and-thread) }\end{array}$ & G3 & S3 & & & & & $\mathrm{x}$ & $\mathrm{x}$ & \\
\hline $\begin{array}{l}\text { Carex aquatilis Herbaceous Vegetation } \\
\text { (Water sedge - Tufted hairgrass) }\end{array}$ & G5 & S4 & & & & $\mathrm{x}$ & & & \\
\hline $\begin{array}{l}\text { Carex pellita - Calamagrostis stricta Herbaceous Vegetation } \\
\text { (Woolly sedge - Narrow-spiked reedgrass) }\end{array}$ & G3 & S3? & & & & $\mathrm{x}$ & & & \\
\hline $\begin{array}{l}\text { Carex praegracilis Herbaceous Vegetation } \\
\text { (Clustered field sedge) }\end{array}$ & G3G4 & S3S4 & $\mathrm{x}$ & & & $\mathrm{x}$ & & $\mathrm{x}$ & \\
\hline $\begin{array}{l}\text { Deschampsia caespitosa Herbaceous Vegetation } \\
\text { (Tufted hairgrass) }\end{array}$ & G4 & S4 & $\mathrm{x}$ & $\mathrm{x}$ & $\mathrm{x}$ & $\mathrm{x}$ & & $\mathrm{x}$ & $\mathrm{x}$ \\
\hline $\begin{array}{l}\text { Eleocharis palustris Herbaceous Vegetation } \\
\text { (Common spikerush) }\end{array}$ & G5 & S5 & & & & $\mathrm{x}$ & & $\mathrm{x}$ & $\mathrm{x}$ \\
\hline
\end{tabular}




\begin{tabular}{|c|c|c|c|c|c|c|c|c|c|}
\hline Plant Associations (Scientific \& Common Name) & $\begin{array}{l}\text { Global } \\
\text { Rank }\end{array}$ & $\begin{array}{l}\text { State } \\
\text { Rank }\end{array}$ & 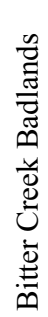 & 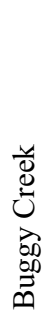 & 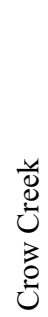 & 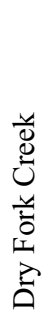 & 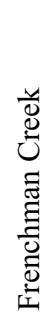 & 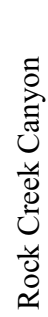 & 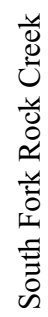 \\
\hline $\begin{array}{l}\text { Eleocharis quinqueflora Herbaceous Vegetation } \\
\text { (Few-flowered spike-rush) }\end{array}$ & G4 & S3 & & & & $\mathrm{x}$ & & & \\
\hline $\begin{array}{l}\text { Elymus lanceolatus - Koeleria macrantha Herbaceous Vegetation } \\
\text { (Thickspike wheatgrass - Prairie junegrass) }\end{array}$ & G? & S? & & & & & $\mathrm{x}$ & & \\
\hline $\begin{array}{l}\text { Elymus lanceolatus - Nassella viridula Herbaceous Vegetation } \\
\text { (Thickspike wheatgrass - Green needlegrass) }\end{array}$ & G4? & G4? & $\mathrm{x}$ & $\mathrm{x}$ & $\mathrm{x}$ & $\mathrm{x}$ & $\mathrm{x}$ & $\mathrm{x}$ & $\mathrm{x}$ \\
\hline $\begin{array}{l}\text { Elymus lanceolatus - Hesperostipa comata Northern Great Plains Herbaceous Vegetation } \\
\text { (Thickspike wheatgrass - Needle-and-thread) }\end{array}$ & G3? & S3? & $\mathrm{x}$ & $\mathrm{x}$ & $\mathrm{x}$ & $\mathrm{x}$ & $\mathrm{x}$ & $\mathrm{x}$ & $\mathrm{x}$ \\
\hline $\begin{array}{l}\text { Elymus lanceolatus - Elymus trachycaulus Herbaceous Vegetation } \\
\text { (Thickspike wheatgrass - Bearded wheatgrass) }\end{array}$ & $\mathrm{G} ?$ & S2S3? & & & $\mathrm{x}$ & & & & \\
\hline $\begin{array}{l}\text { Elymus trachycaulus - Nassella viridula Herbaceous Vegetation } \\
\text { (Bearded wheatgrass -- Green needlegrass) }\end{array}$ & G1G3? & S1S3? & & & $\mathrm{x}$ & & & & \\
\hline $\begin{array}{l}\text { Hesperostipa comata - Bouteloua gracilis - Carex filifolia Herbaceous Vegetation } \\
\text { (Needle-and-thread - Blue grama - Threadleaved sedge) }\end{array}$ & G5 & S5 & $\mathrm{x}$ & $\mathrm{x}$ & & $\mathrm{x}$ & $\mathrm{x}$ & $\mathrm{x}$ & \\
\hline $\begin{array}{l}\text { Hesperostipa curtiseta - (Elymus lanceolatus) Herbaceous Vegetation } \\
\text { (Northern Porcupine grass - Thickspike wheatgrass) }\end{array}$ & G? & S2S3? & $\mathrm{x}$ & $\mathrm{x}$ & $\mathrm{x}$ & $\mathrm{x}$ & & & \\
\hline $\begin{array}{l}\text { Hordeum jubatum Herbaceous Vegetation } \\
\text { (Foxtail barley) }\end{array}$ & G4 & S4 & $\mathrm{x}$ & $\mathrm{x}$ & $\mathrm{x}$ & $\mathrm{x}$ & & $\mathrm{x}$ & $\mathrm{x}$ \\
\hline $\begin{array}{l}\text { Muhlenbergia cuspidata - Bouteloua gracilis Herbaceous Vegetation } \\
\text { (Plains muhly - Blue grama) }\end{array}$ & G2G3? & S2S3? & $\mathrm{x}$ & $\mathrm{x}$ & $\mathrm{x}$ & & $\mathrm{x}$ & & \\
\hline $\begin{array}{l}\text { Pascopyrum smithii - Bouteloua gracilis Northern Plains Herbaceous Vegetation } \\
\text { (Western wheatgrass - Blue grama grass) }\end{array}$ & G5 & S5? & $\mathrm{x}$ & $\mathrm{x}$ & $\mathrm{x}$ & $\mathrm{x}$ & $\mathrm{x}$ & $\mathrm{x}$ & $\mathrm{x}$ \\
\hline $\begin{array}{l}\text { Pascopyrum smithii - (Carex duriuscula) Herbaceous Vegetation } \\
\text { (Western wheatgrass - (Needleleaf sedge)) }\end{array}$ & G3? & S3? & $\mathrm{x}$ & $\mathrm{x}$ & $\mathrm{x}$ & $\mathrm{x}$ & $\mathrm{x}$ & & $\mathrm{x}$ \\
\hline
\end{tabular}




\begin{tabular}{|c|c|c|c|c|c|c|c|c|c|}
\hline Plant Associations (Scientific \& Common Name) & $\begin{array}{l}\text { Global } \\
\text { Rank }\end{array}$ & $\begin{array}{l}\text { State } \\
\text { Rank }\end{array}$ & 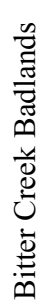 & 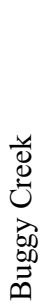 & 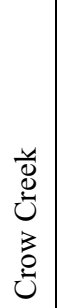 & 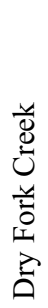 & 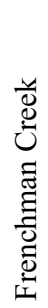 & 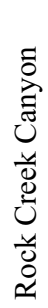 & 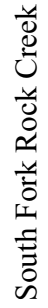 \\
\hline $\begin{array}{l}\text { Pascopyrum smithii - Distichlis spicata Herbaceous Vegetation } \\
\text { (Western wheatgrass - Inland saltgrass) }\end{array}$ & G4 & S3S4 & $\mathrm{x}$ & $\mathrm{x}$ & $\mathrm{x}$ & $\mathrm{x}$ & & & \\
\hline $\begin{array}{l}\text { Pascopyrum smithii - Eleocharis spp. Herbaceous Vegetation } \\
\text { (Western wheatgrass - Spike-rush) }\end{array}$ & G1 & S1S2? & & & $\mathrm{x}$ & $\mathrm{x}$ & & $\mathrm{x}$ & $\mathrm{x}$ \\
\hline $\begin{array}{l}\text { Pascopyrum smithii - Nassella viridula Herbaceous Vegetation } \\
\text { (Western wheatgrass - Green needlegrass) }\end{array}$ & G3G4 & $\mathrm{S} 4 ?$ & $\mathrm{x}$ & $\mathrm{x}$ & $\mathrm{x}$ & $\mathrm{x}$ & $\mathrm{x}$ & & $\mathrm{x}$ \\
\hline $\begin{array}{l}\text { Pascopyrum smithii - Poa secunda Herbaceous Vegetation } \\
\text { (Western wheatgrass - Sandberg's bluegrass) }\end{array}$ & G2G3? & S2S3? & $\mathrm{x}$ & $\mathrm{x}$ & & $\mathrm{x}$ & & & $\mathrm{x}$ \\
\hline $\begin{array}{l}\text { Pascopyrum smithii - Hesperostipa comata Northern Plains Herbaceous Vegetation } \\
\text { (Western wheatgrass - Needle-and-thread grass) }\end{array}$ & G4? & S4? & & $\mathrm{x}$ & & $\mathrm{x}$ & $\mathrm{x}$ & $\mathrm{x}$ & $\mathrm{x}$ \\
\hline $\begin{array}{l}\text { Phalaris arundinacea Western Herbaceous Vegetation } \\
\text { (Reed canary grass) }\end{array}$ & G5 & $\mathrm{S} 4$ & $\mathrm{x}$ & & & & & & \\
\hline $\begin{array}{l}\text { Poa secunda - Koeleria macrantha Herbaceous Vegetation } \\
\text { (Sandberg's bluegrass - Prairie junegrass) }\end{array}$ & $\mathrm{G} ?$ & S2S3? & $\mathrm{x}$ & $\mathrm{x}$ & & & & & $\mathrm{x}$ \\
\hline $\begin{array}{l}\text { Pseudoroegneria spicata - Bouteloua gracilis Herbaceous Vegetation } \\
\text { (Bluebunch wheatgrass - Plains muhly) }\end{array}$ & G4 & S3 & & $\mathrm{x}$ & & & $\mathrm{x}$ & $\mathrm{x}$ & \\
\hline $\begin{array}{l}\text { Puccinellia nuttalliana Herbaceous Vegetation } \\
\text { (Nuttall's alkaligrass) }\end{array}$ & G3? & S3? & & $\mathrm{x}$ & & & & & \\
\hline $\begin{array}{l}\text { Schizachyrium scoparium - Carex inops ssp. heliophila Herbaceous Vegetation } \\
\text { (Little bluestem - Sun sedge) }\end{array}$ & G3 & S3 & $\mathrm{x}$ & & & & & & \\
\hline $\begin{array}{l}\text { Schizachyrium scoparium-Bouteloua (gracilis, curtipendula) - Carex filifolia } \\
\text { Herbaceous Vegetation } \\
\text { (Little bluestem - Grama grass (Blue or sideoats) -Threadleaved sedge) }\end{array}$ & G3G4 & S3 & $\mathrm{x}$ & $\mathrm{x}$ & & & & & \\
\hline $\begin{array}{l}\text { Schoenoplectus acutus Herbaceous Vegetation } \\
\text { (Hardstem bulrush) }\end{array}$ & G5 & S5 & & & & $\mathrm{x}$ & & $\mathrm{x}$ & \\
\hline
\end{tabular}




\begin{tabular}{|c|c|c|c|c|c|c|c|c|c|}
\hline Plant Associations (Scientific \& Common Name) & $\begin{array}{c}\text { Global } \\
\text { Rank }\end{array}$ & $\begin{array}{l}\text { State } \\
\text { Rank }\end{array}$ & 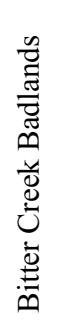 & 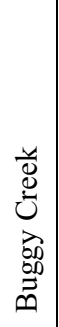 & 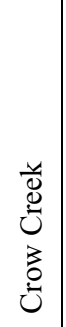 & 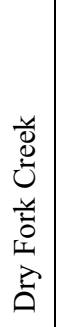 & 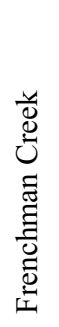 & 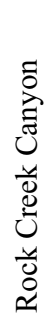 & 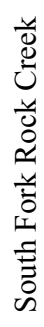 \\
\hline $\begin{array}{l}\text { Spartina gracilis Herbaceous Vegetation } \\
\text { (Alkali cordgrass) }\end{array}$ & GU & S1S3? & $\mathrm{x}$ & $\mathrm{x}$ & & & & & $\mathrm{x}$ \\
\hline $\begin{array}{l}\text { Spartina pectinata Western Herbaceous Vegetation } \\
\text { (Prairie cordgrass) }\end{array}$ & G3? & S3? & $\mathrm{x}$ & & & $\mathrm{x}$ & & $\mathrm{x}$ & \\
\hline $\begin{array}{l}\text { Typha latifolia Western Herbaceous Vegetation } \\
\text { (Common cattail) }\end{array}$ & G5 & S5 & & $\mathrm{x}$ & & $\mathrm{x}$ & & $\mathrm{x}$ & $\mathrm{x}$ \\
\hline
\end{tabular}




\section{Appendix E: Natural Community Photographs}

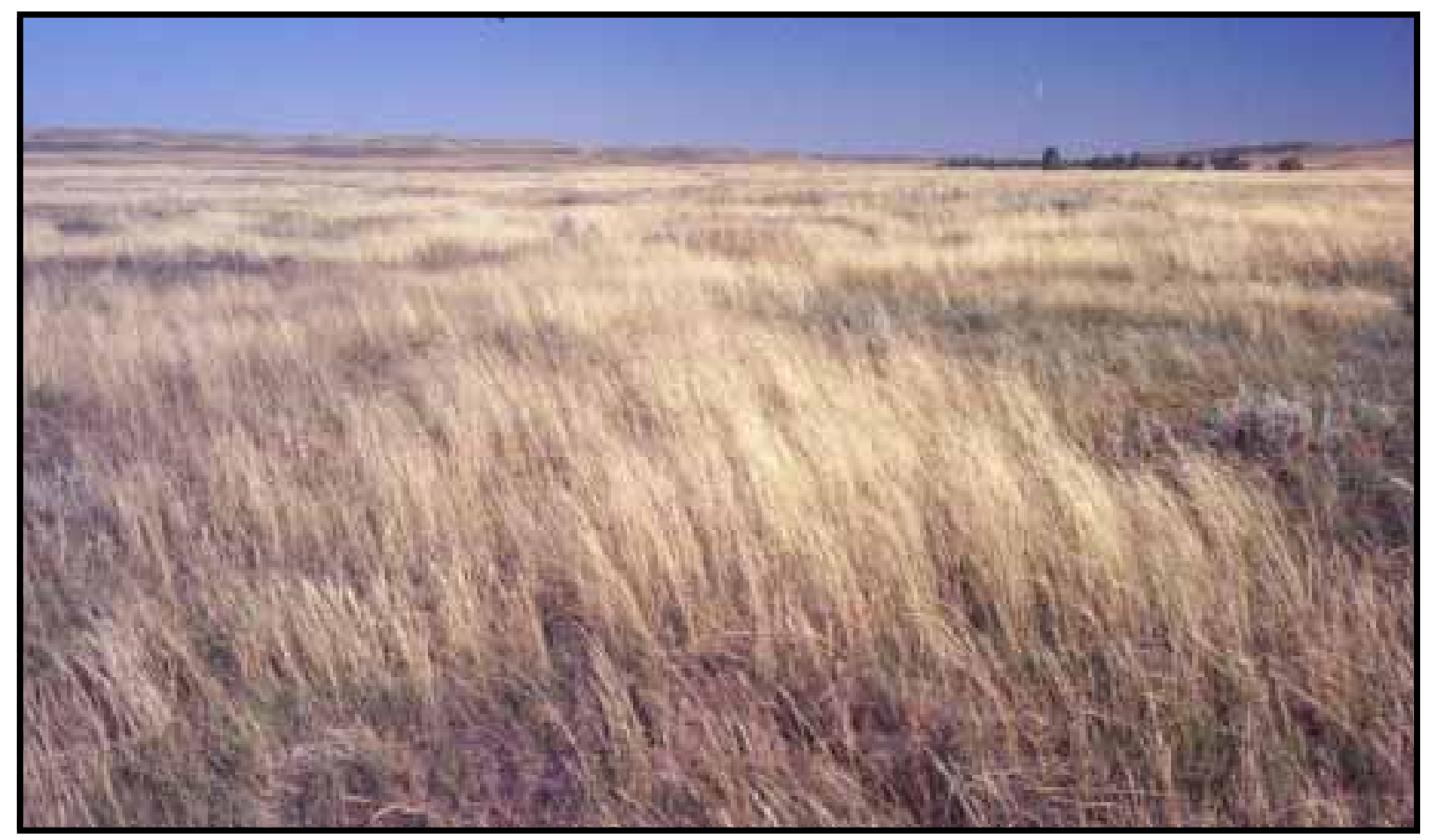

Western wheatgrass - Inland saltgrass Herbaceous Vegetation

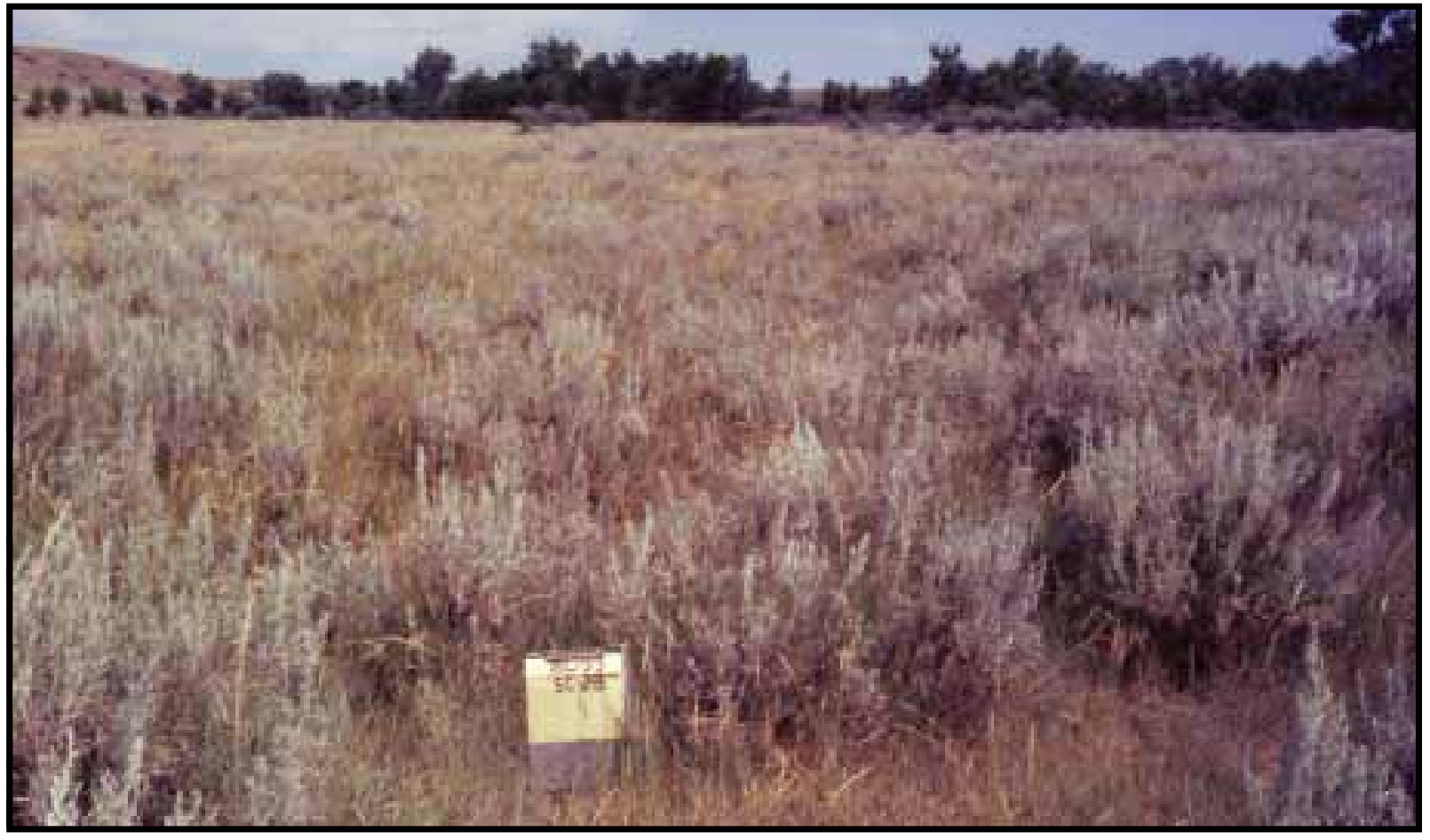

Silver sagebrush / Western wheatgrass Shrubland 


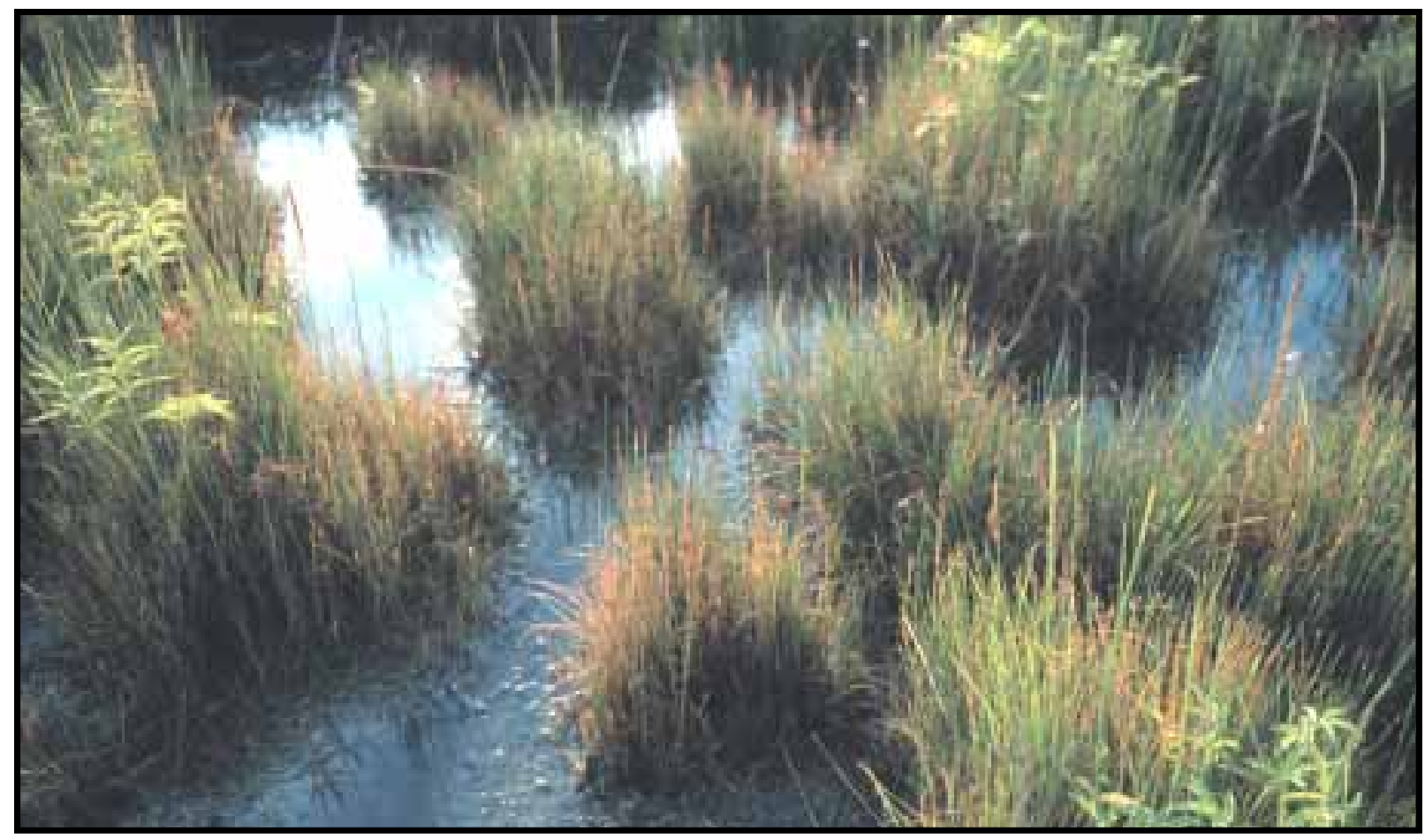

Few-flowered spike-rush Herbaceous Vegetation

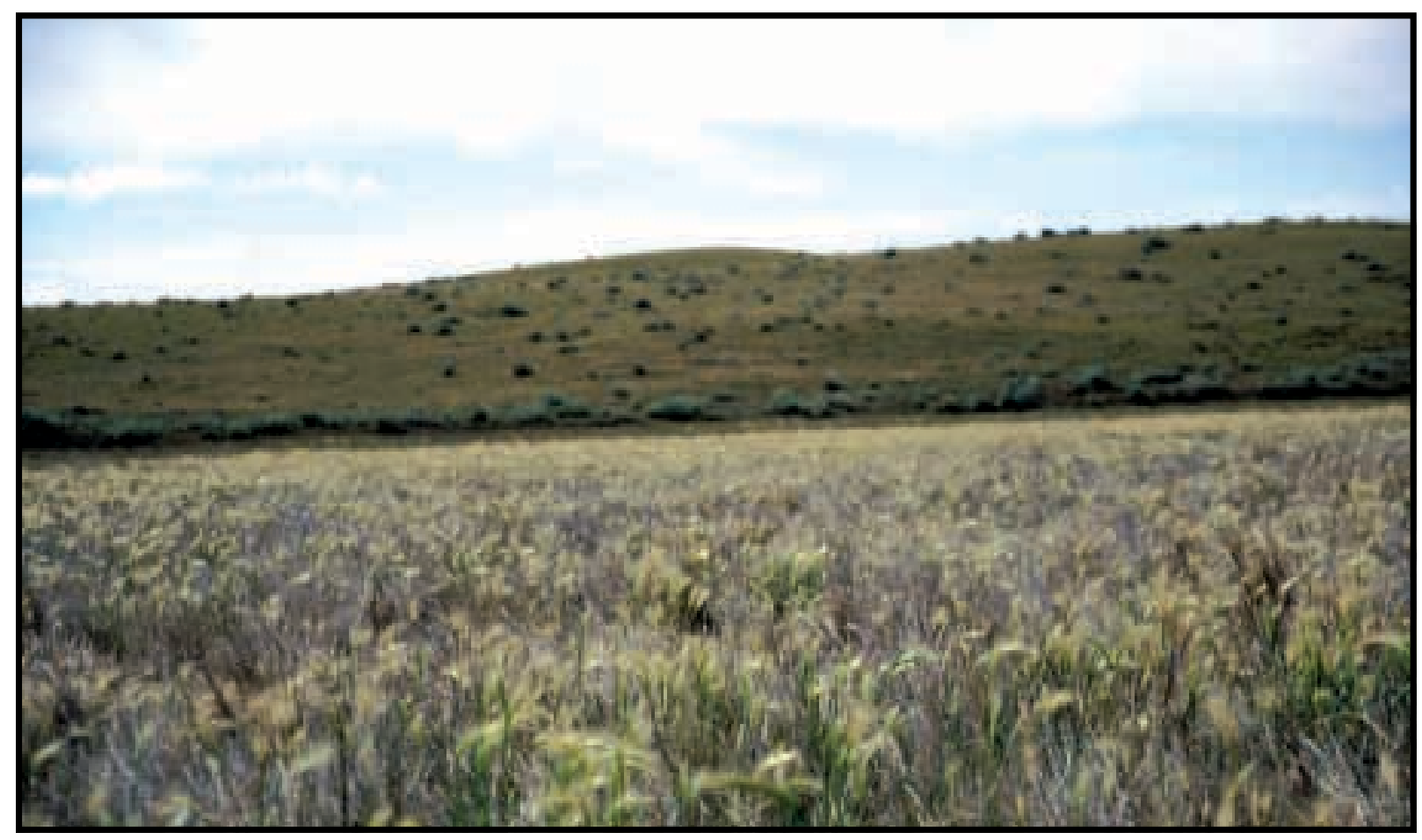

Foxtail barley Herbaceous Vegetation 


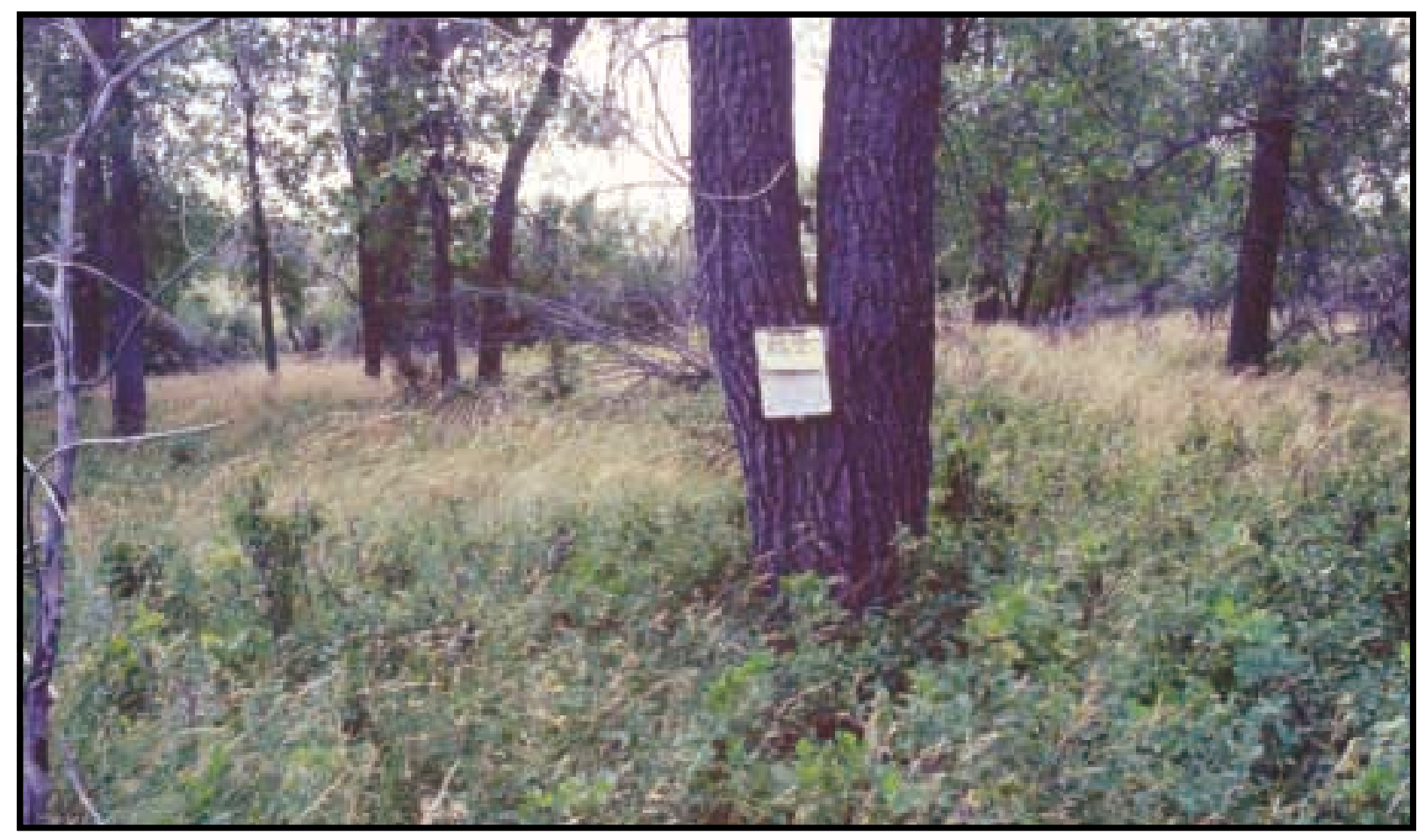

Plains Cottonwood / Western snowberry Woodland

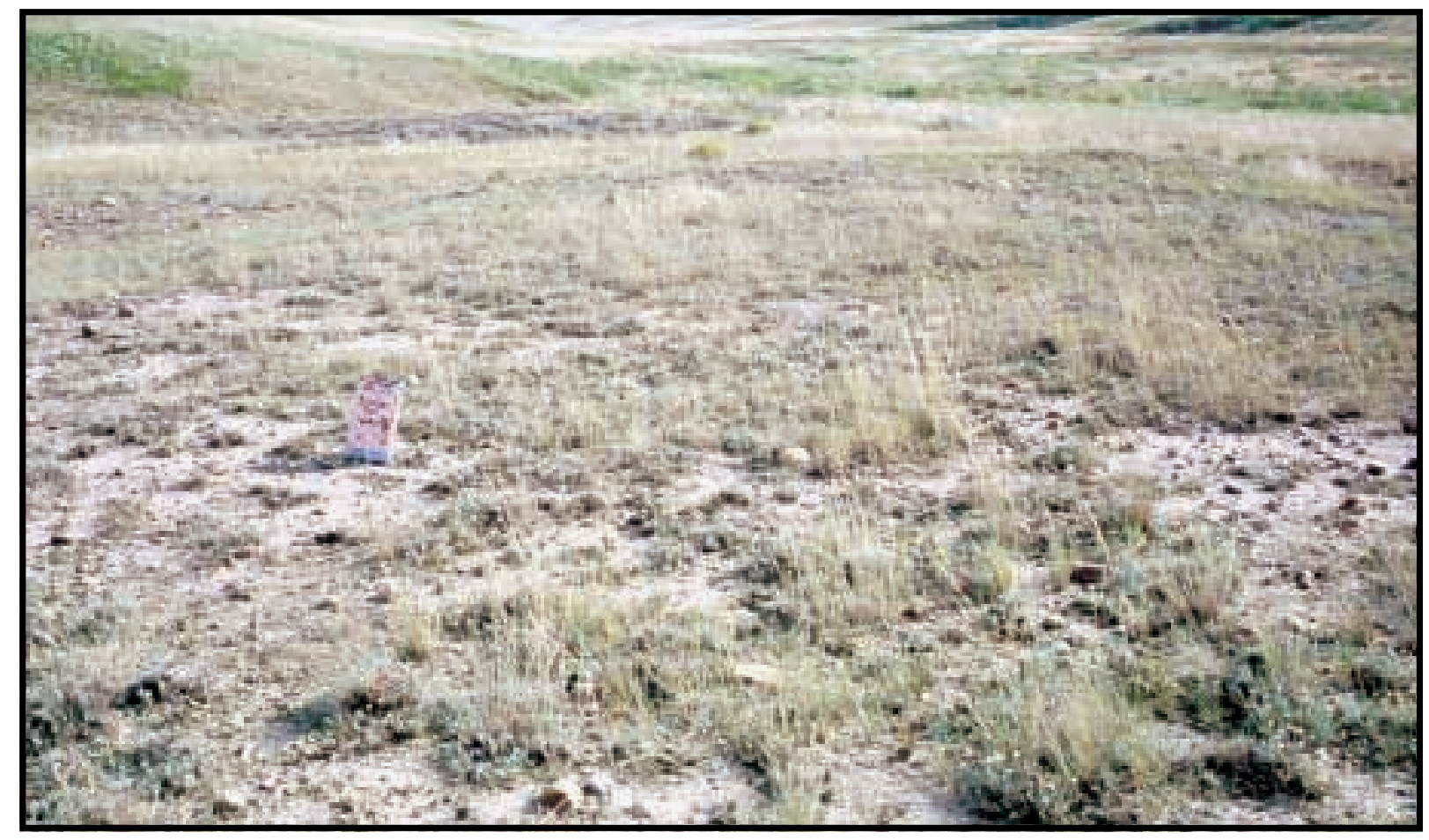

Few-flowered wild buckwheat - Broom snakeweed Badlands Sparse Vegetation 


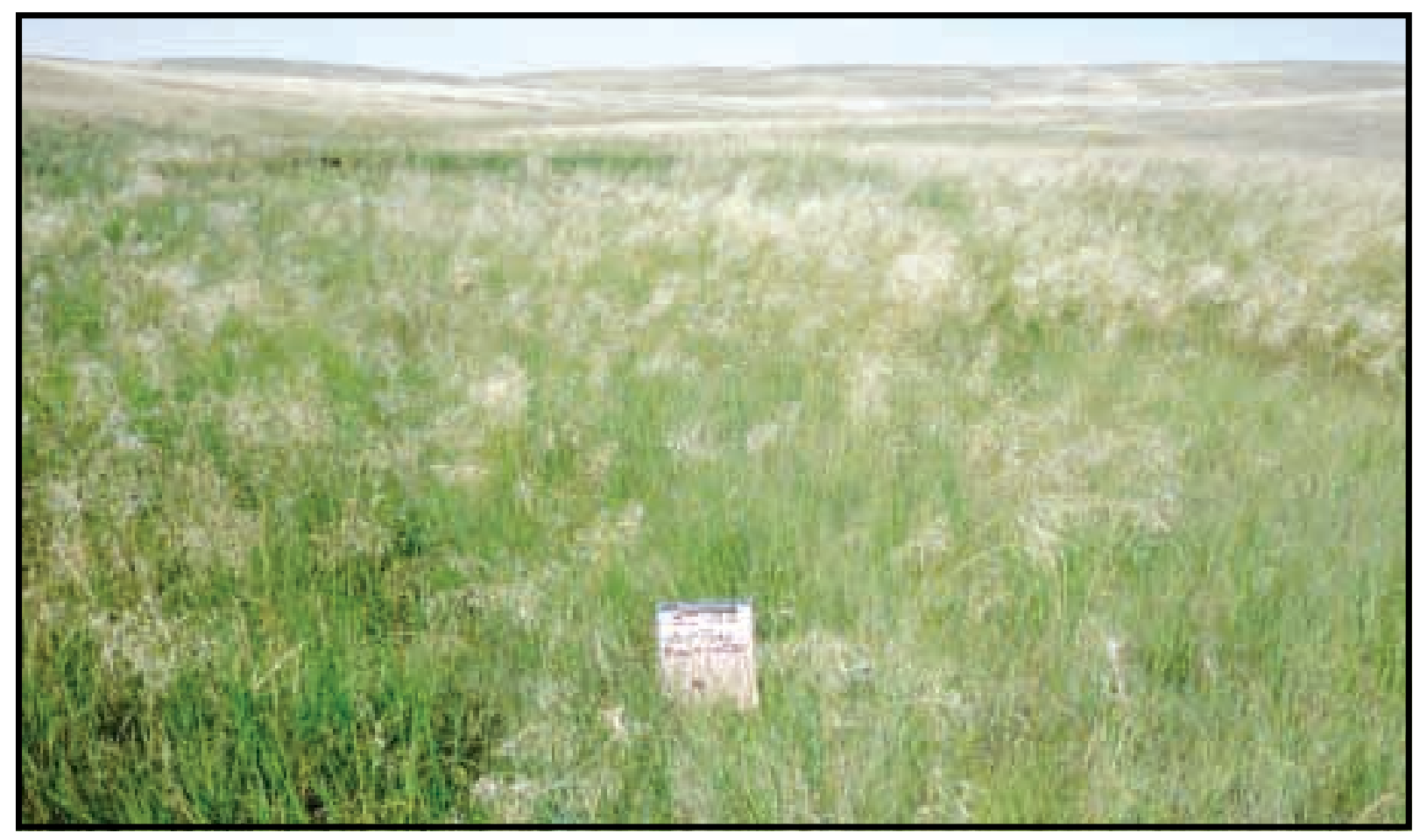

Clustered field sedge Herbaceous Vegetation

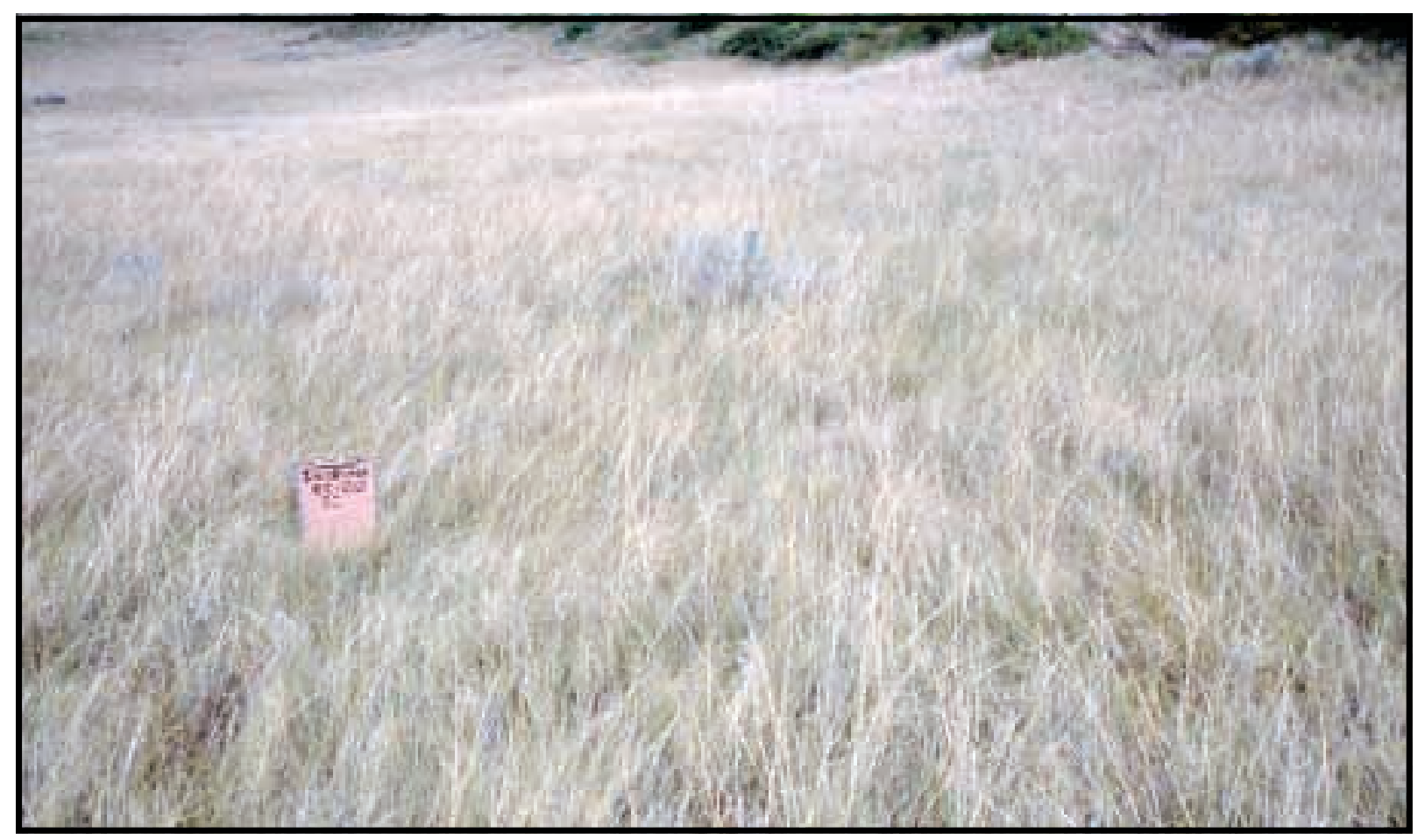

Bearded wheatgrass - Green needlegrass Herbaceous Vegetation 


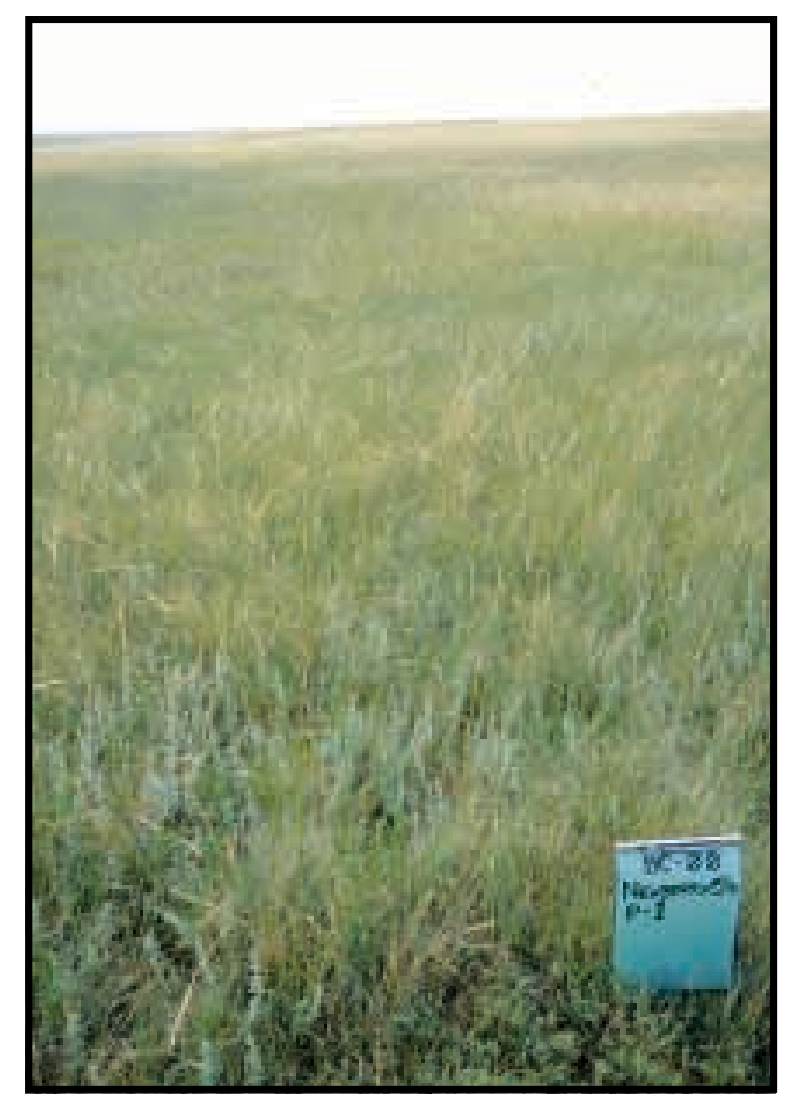

Thickspike wheatgrass - Green needlegrass Herbaceous Vegetation

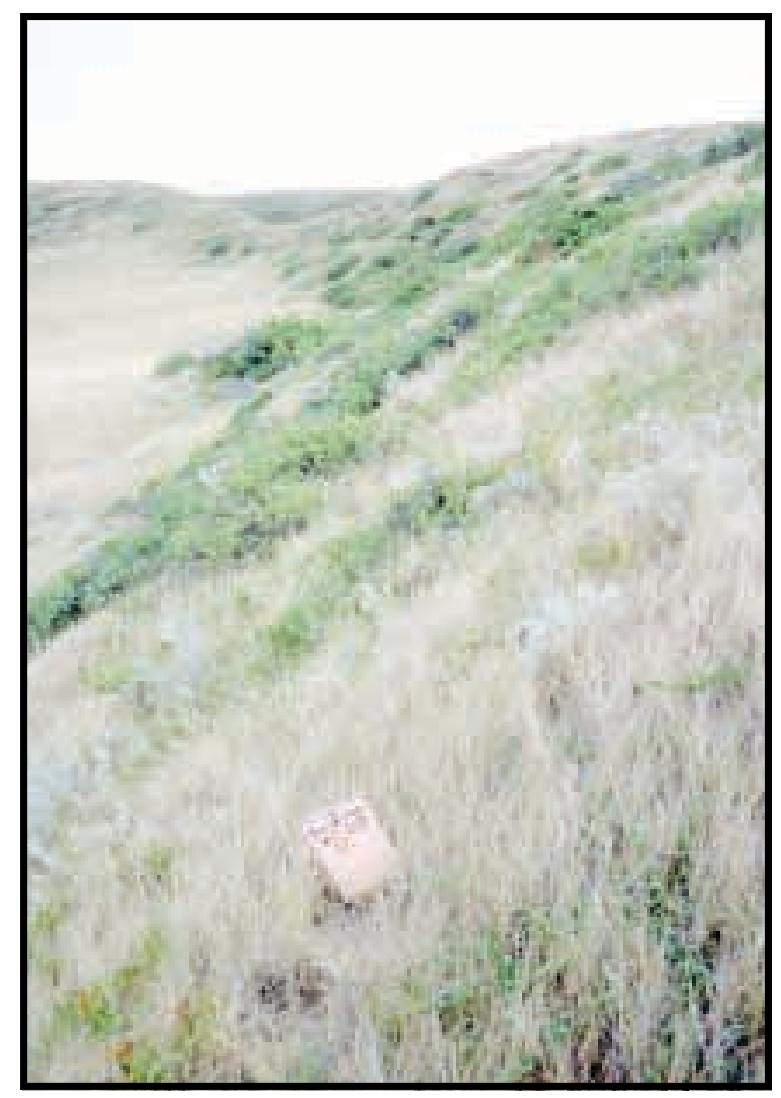

Skunkbush sumac / Thickspike wheatgrass Green needlegrass Shrub Herbaceous

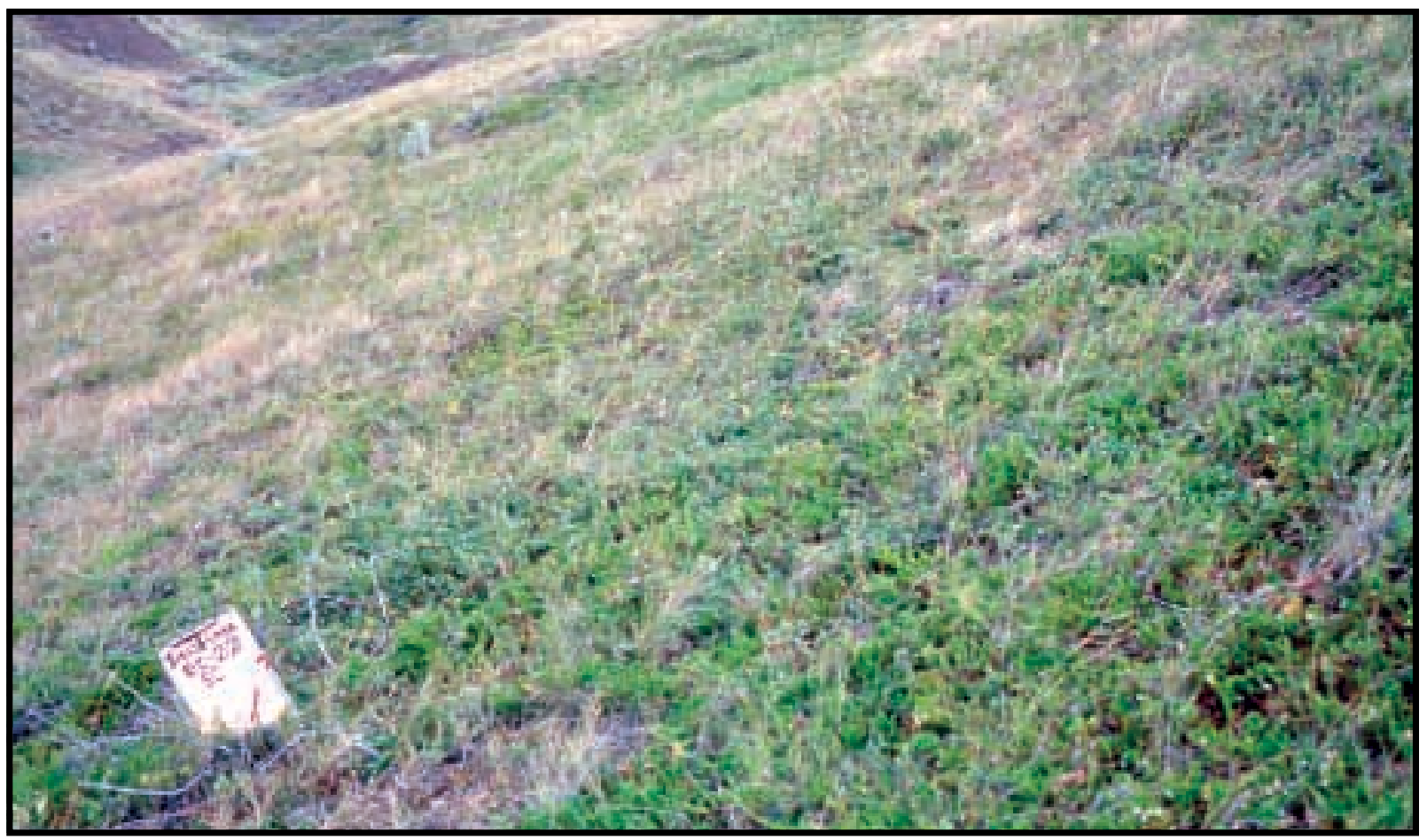

Creeping juniper / Bearded wheatgrass Dwarf-shrubland 


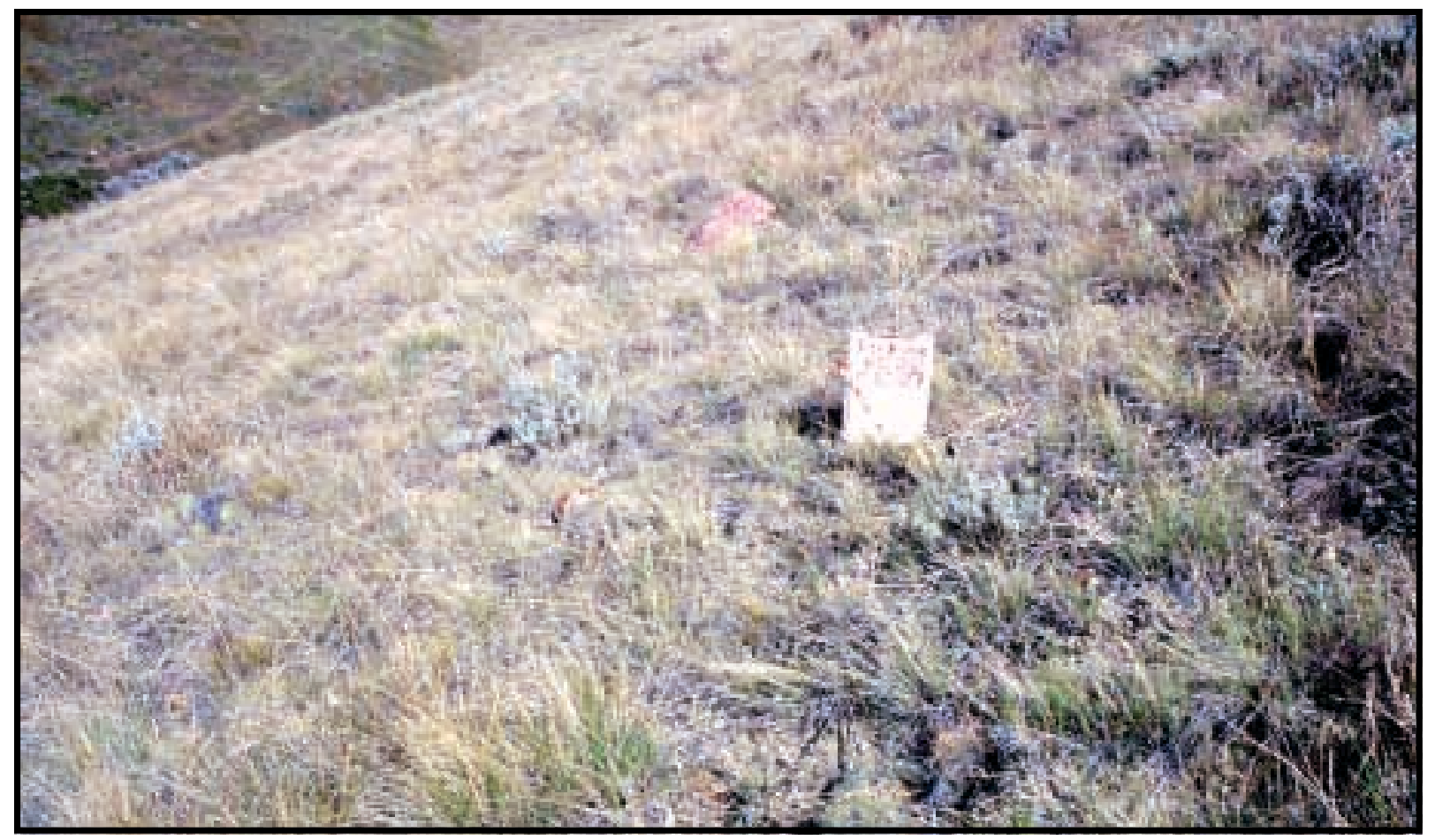

Plains muhly - Blue grama grass Herbaceous Vegetation

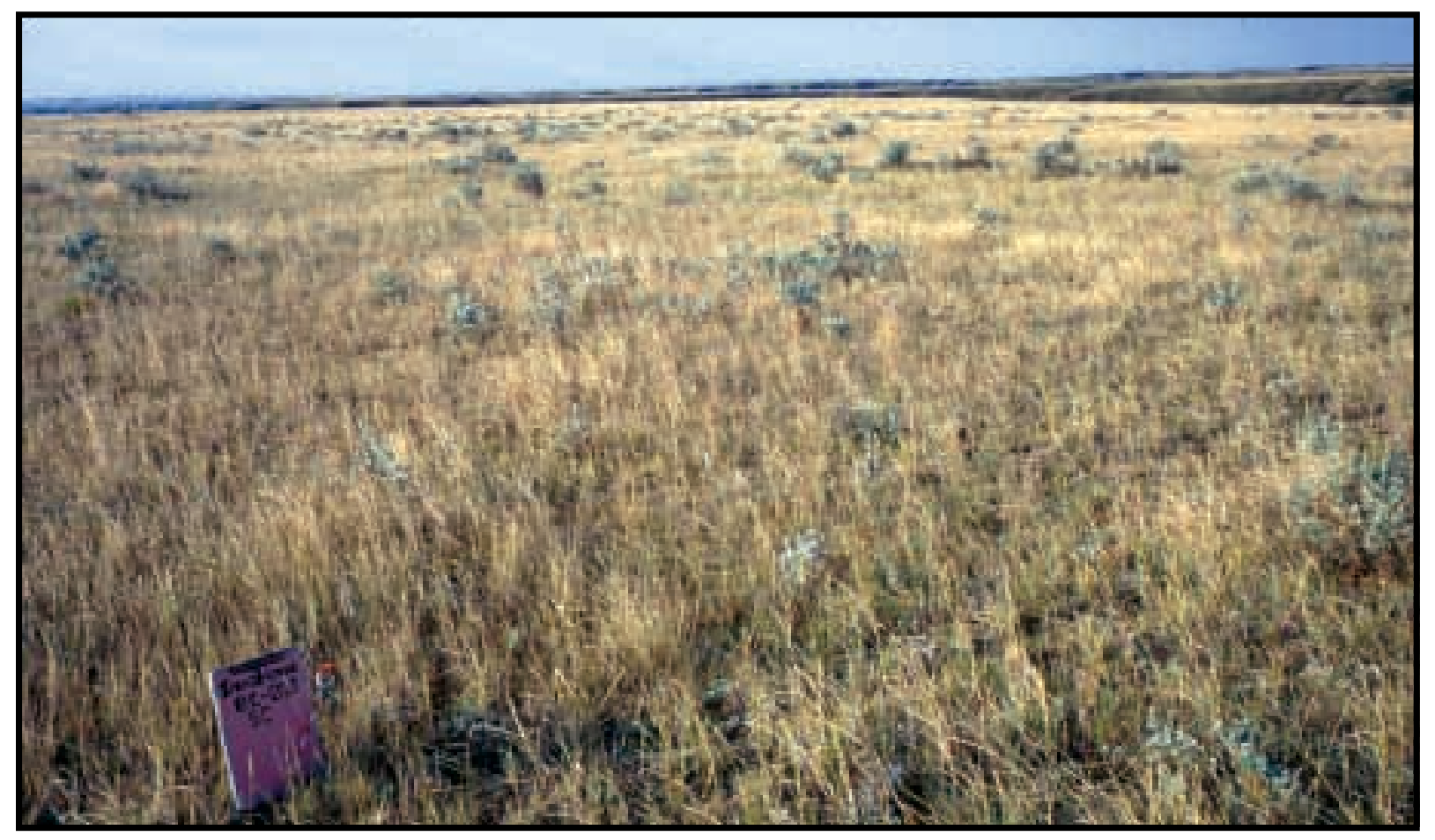

Thickspike wheatgrass - Needle-and-thread Northern Great Plains Herbaceous Vegetation 


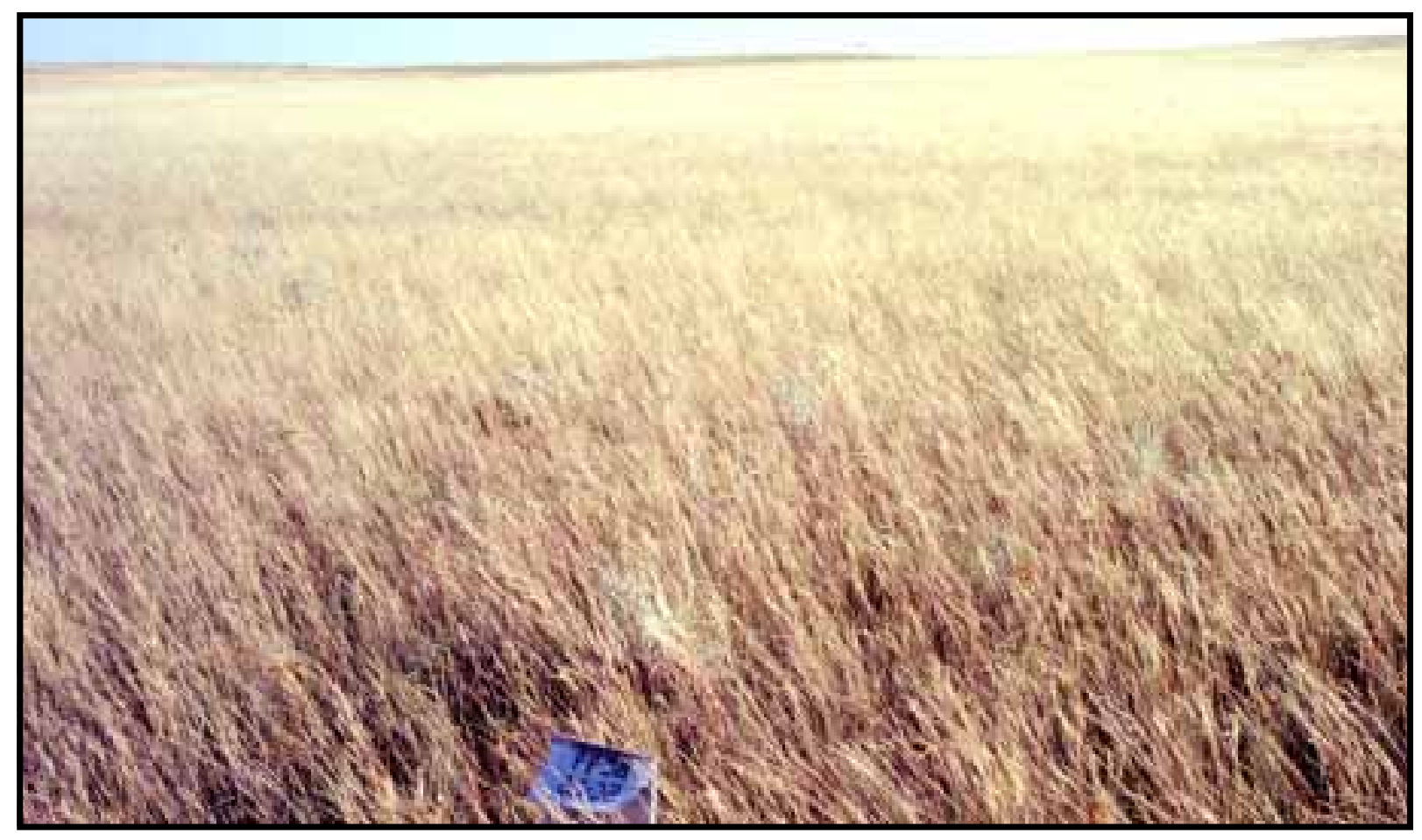

Western wheatgrass Herbaceous Vegetation

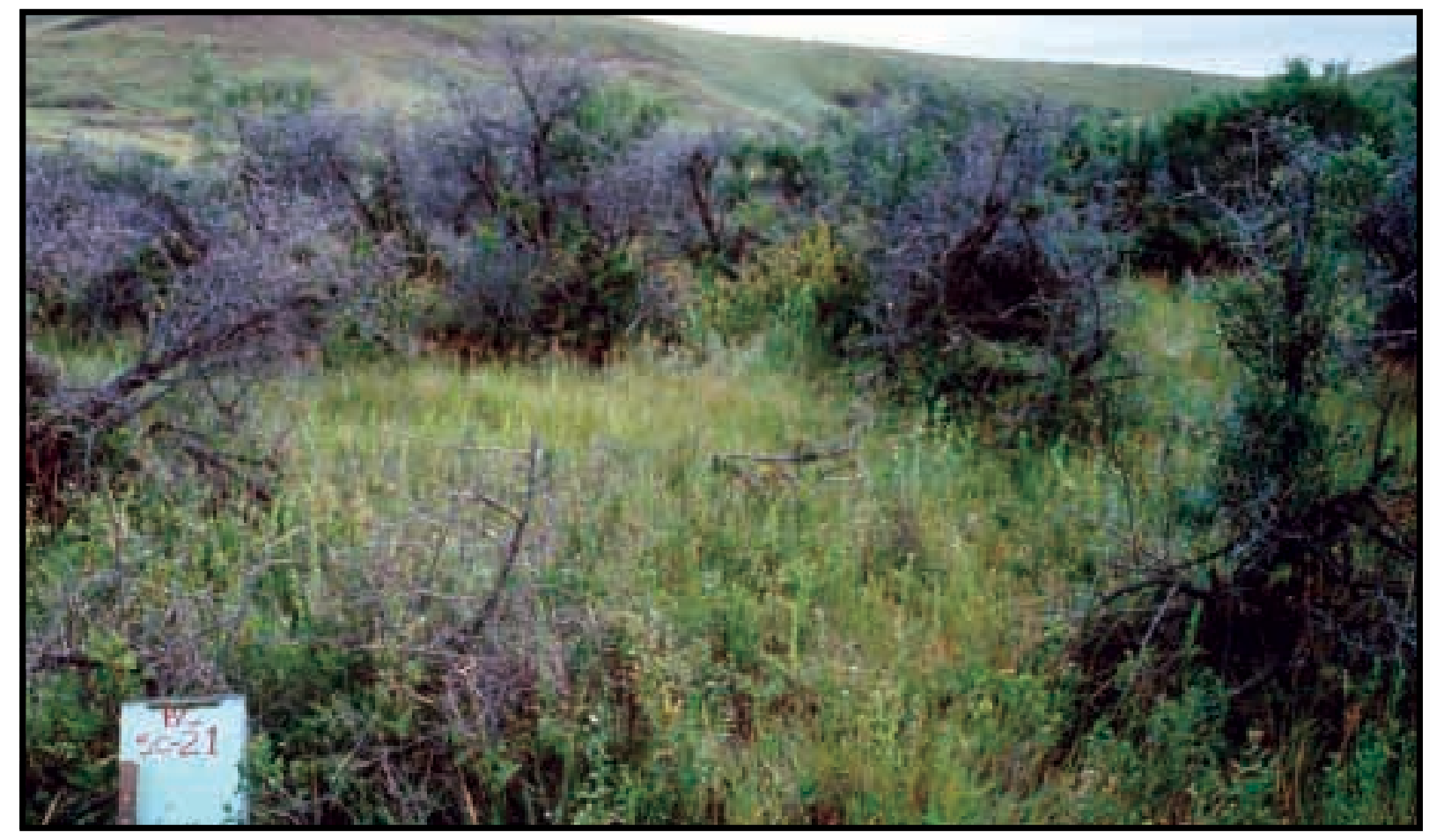

Thorny Buffaloberry Shrubland 


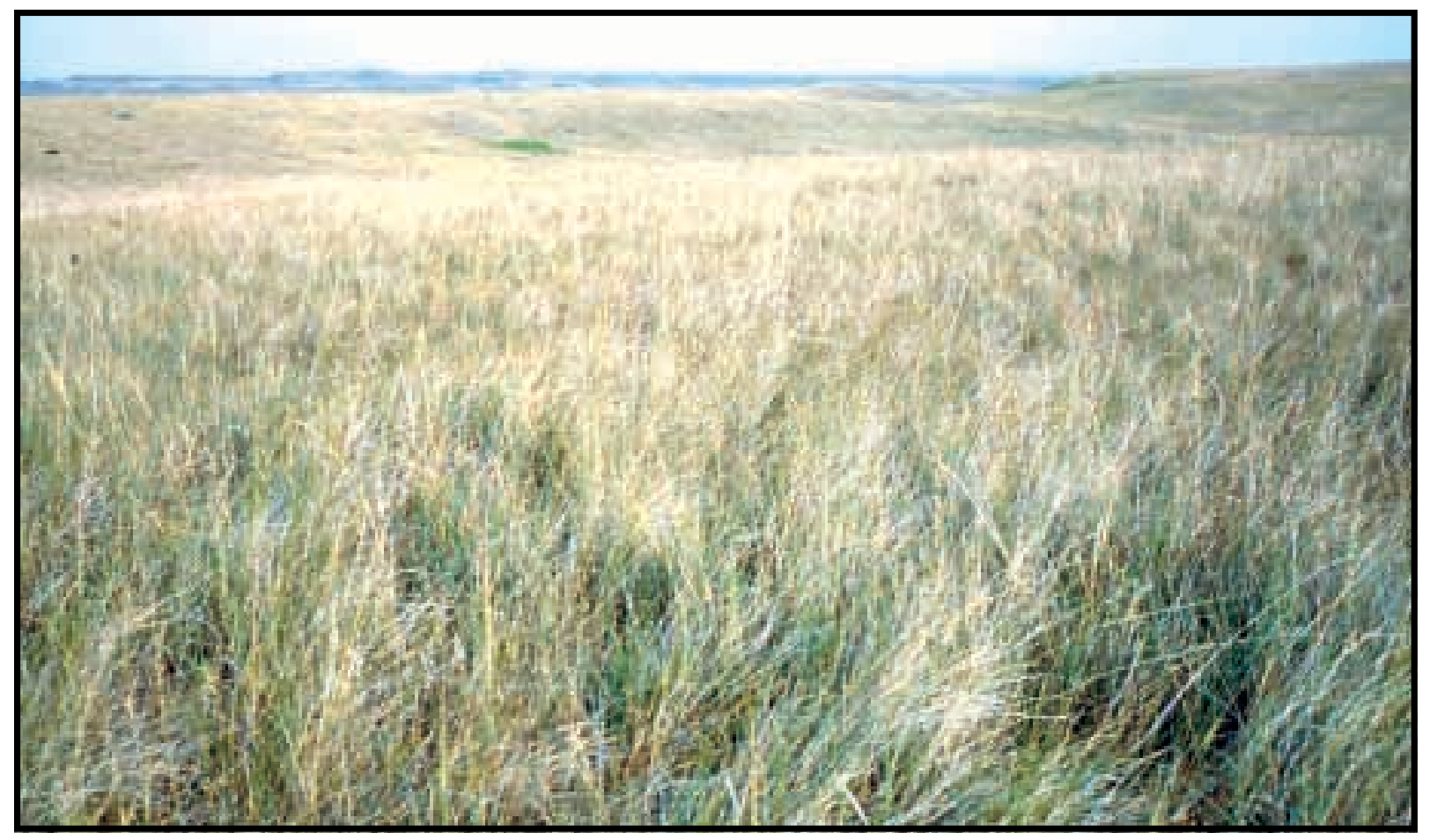

Thickspike wheatgrass - Bearded wheatgrass Herbaceous Vegetation

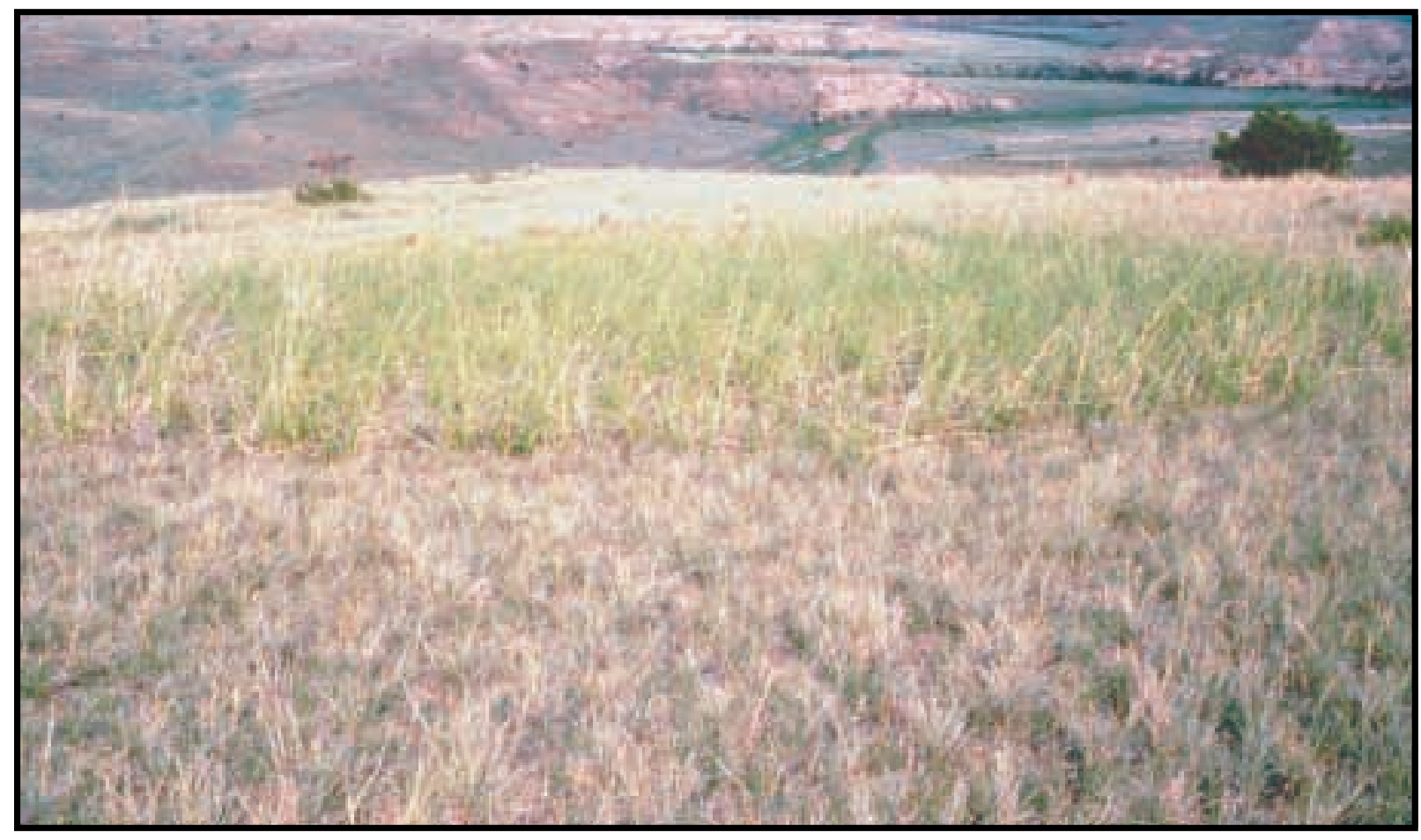

Western wheatgrass - Needle-and-thread Herbaceous Vegetation 


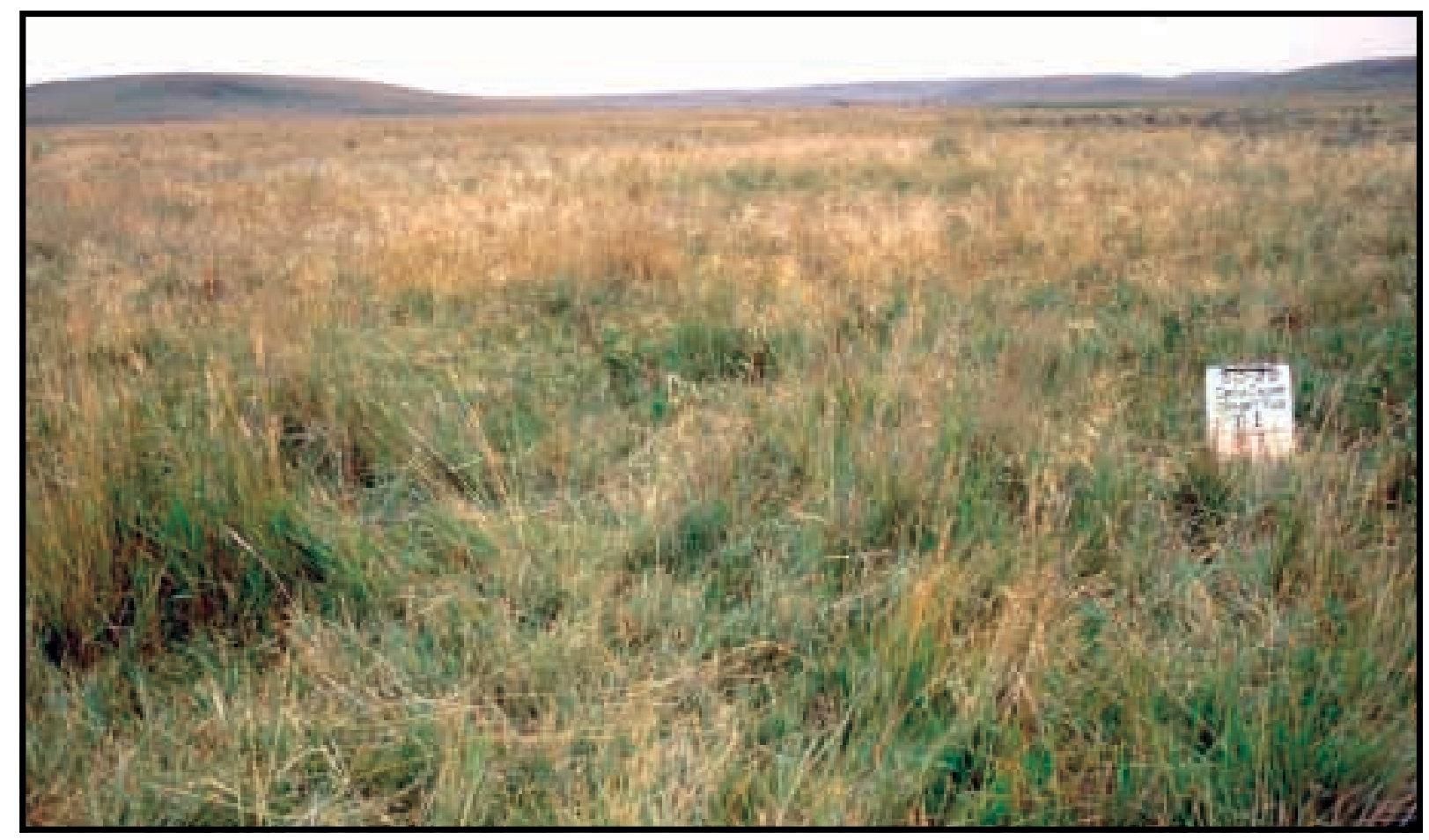

Tufted hairgrass Herbaceous Vegetation

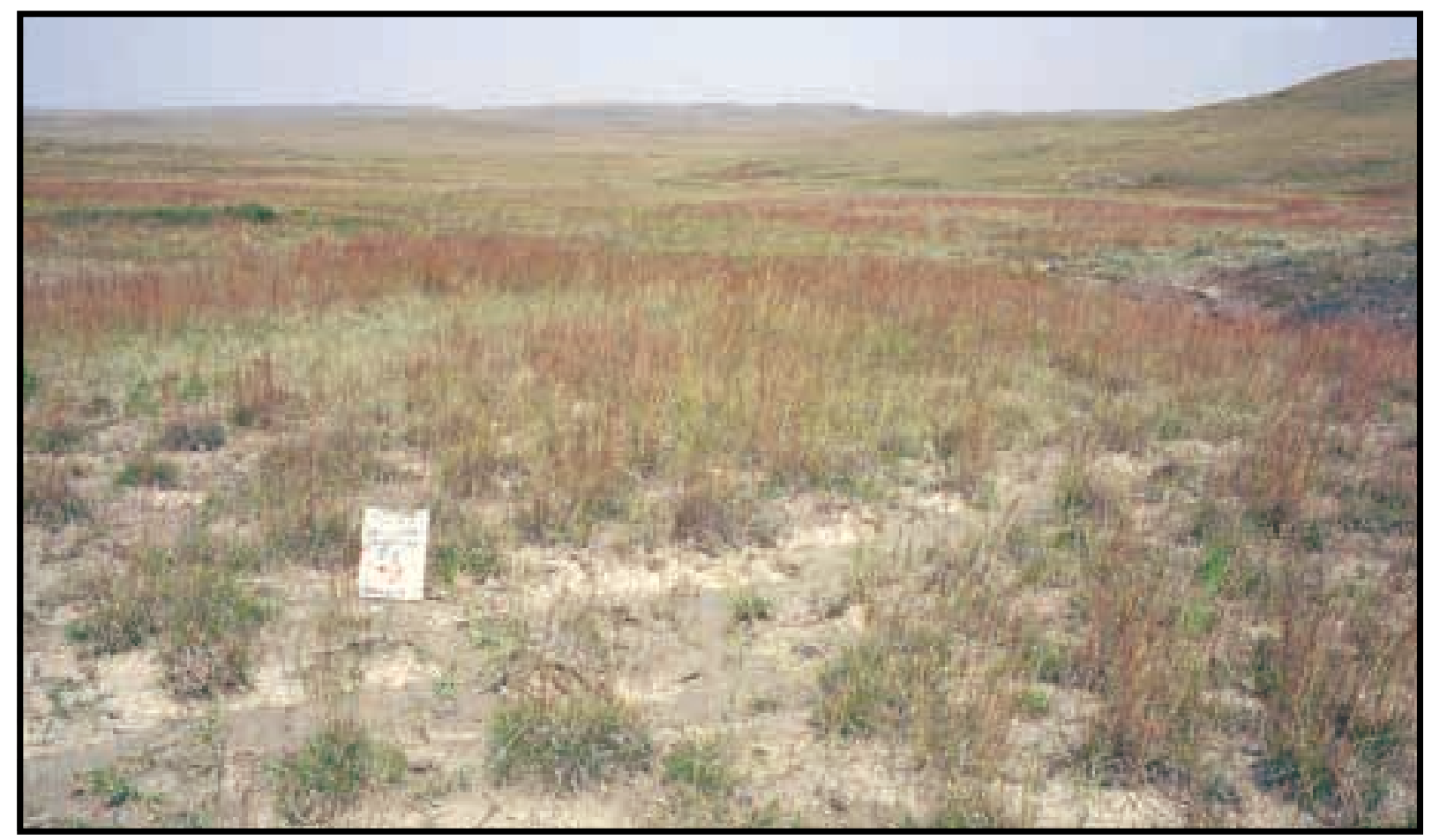

Little bluestem - Sun sedge Herbaceous Vegetation 


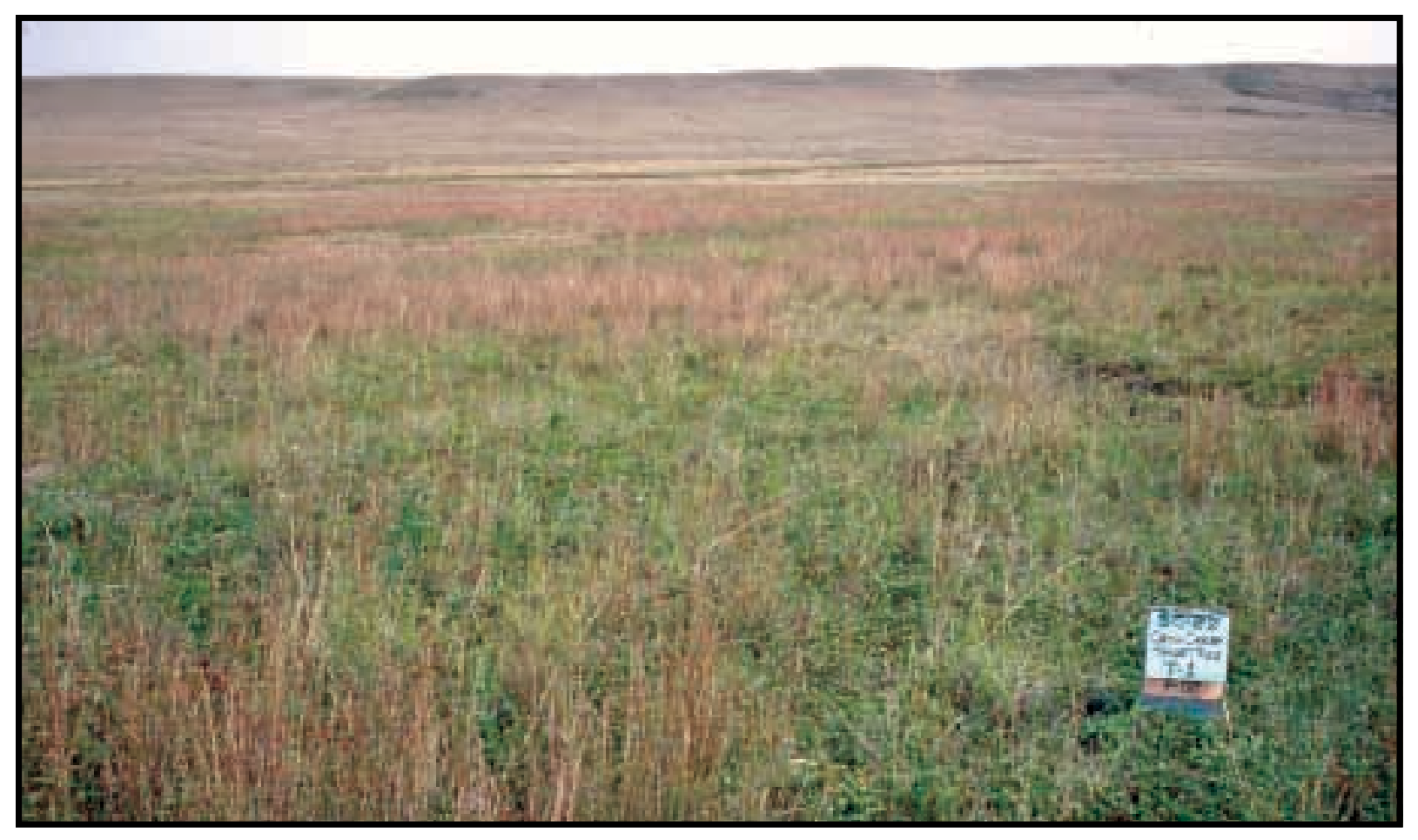

Creeping juniper / Little bluestem Dwarf-shrubland

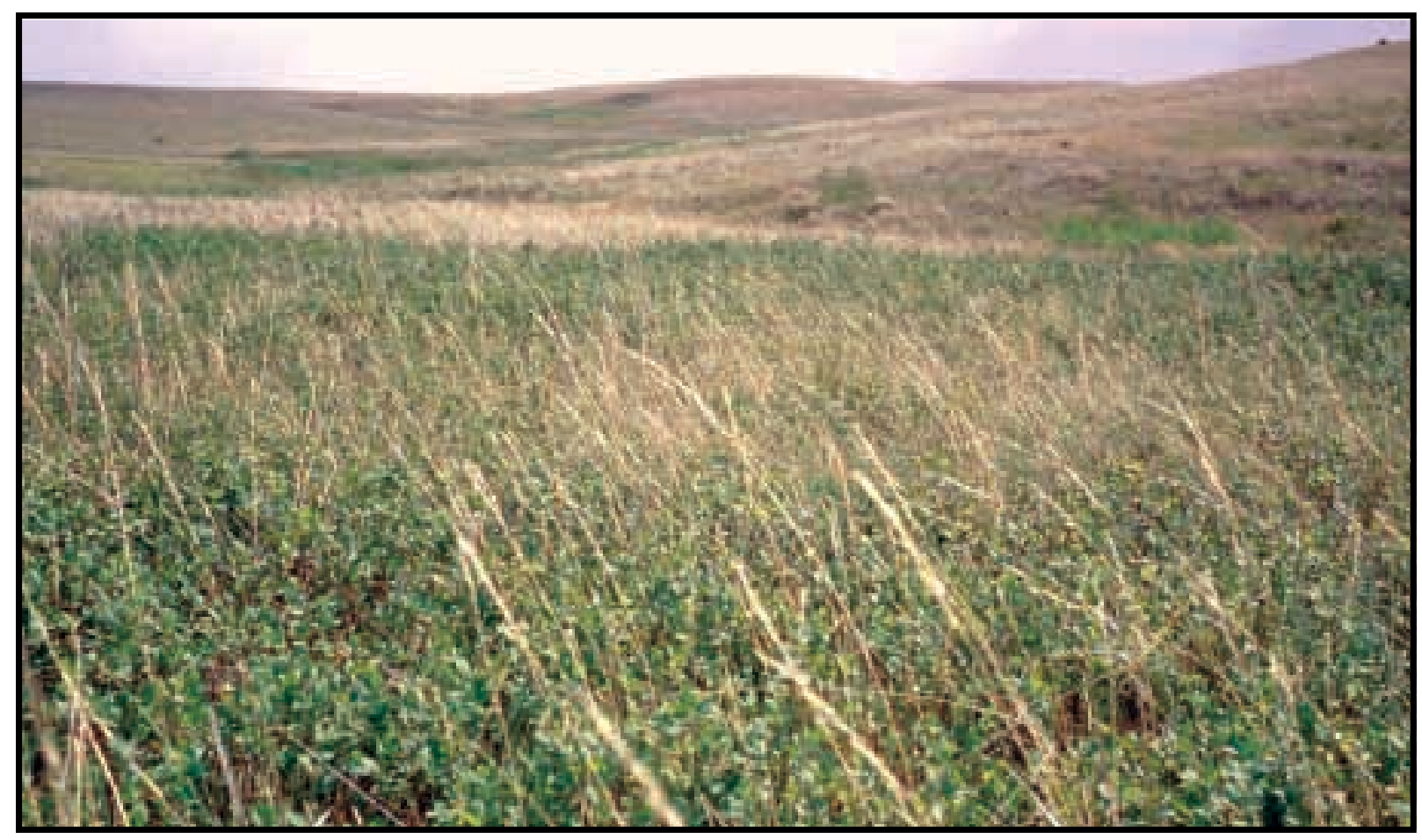

Western snowberry Shrubland 


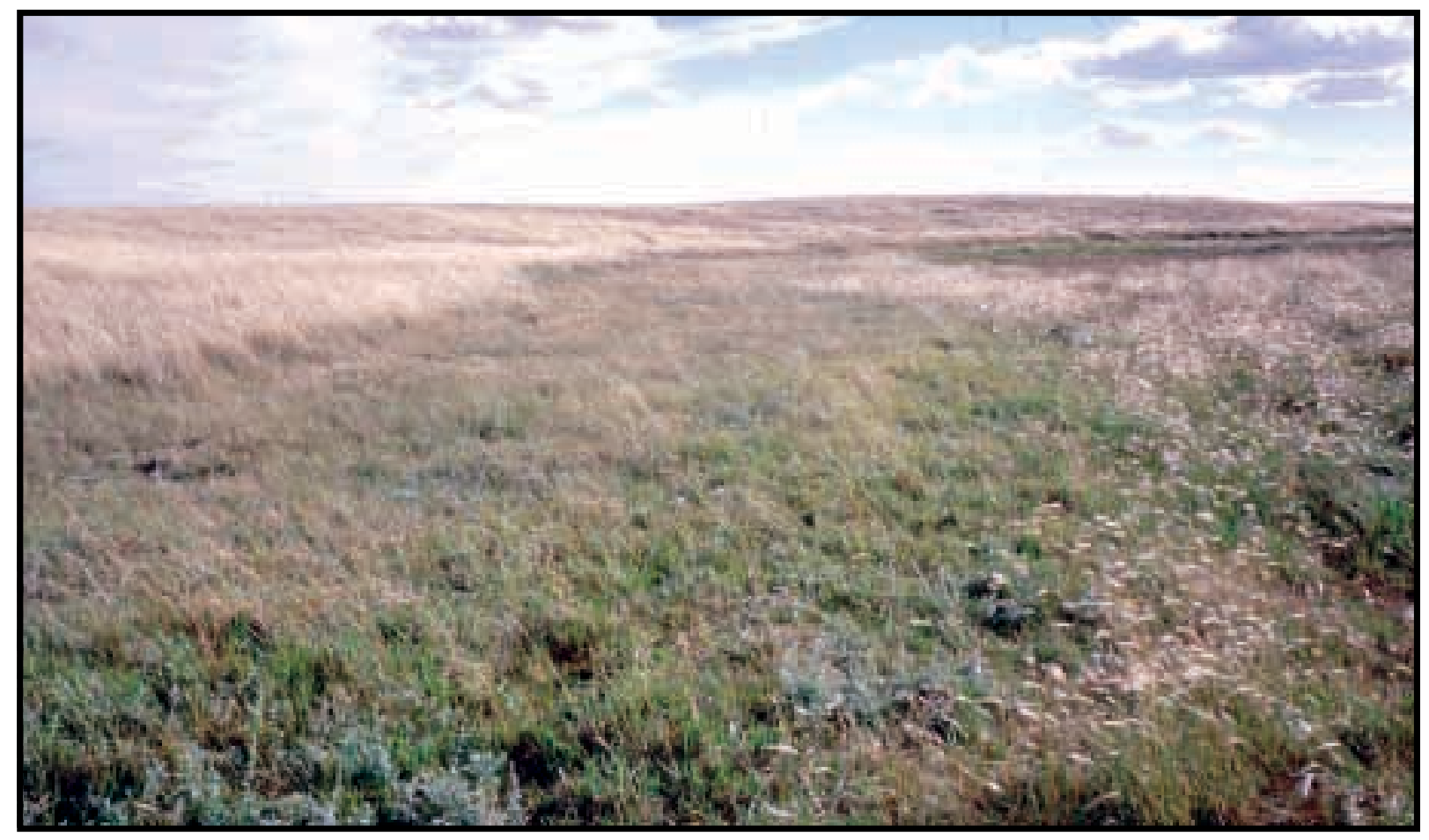

Common spikerush Herbaceous Vegetation

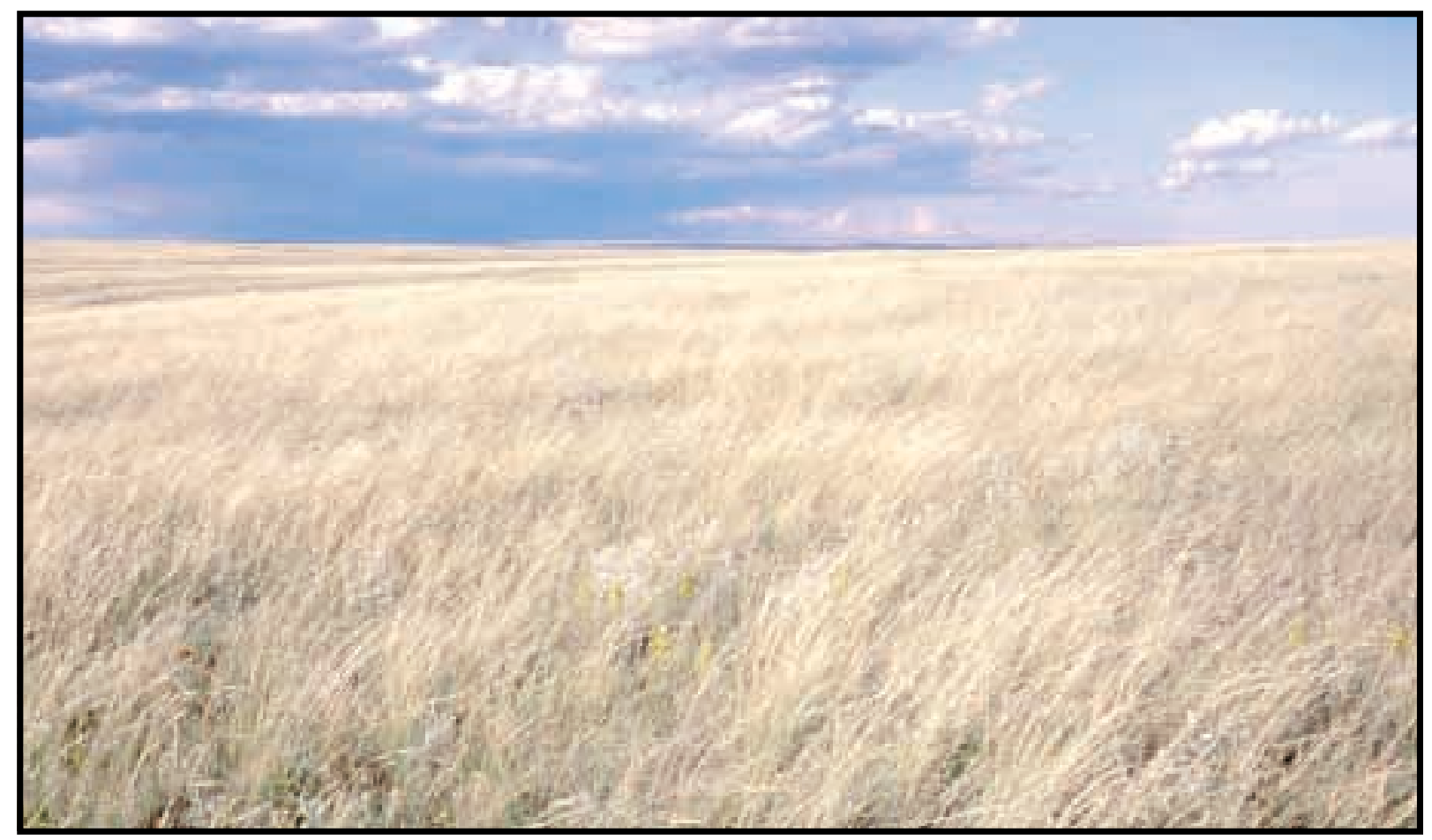

Northern porcupine grass - (Thickspike wheatgrass) Herbaceous Vegetation. 


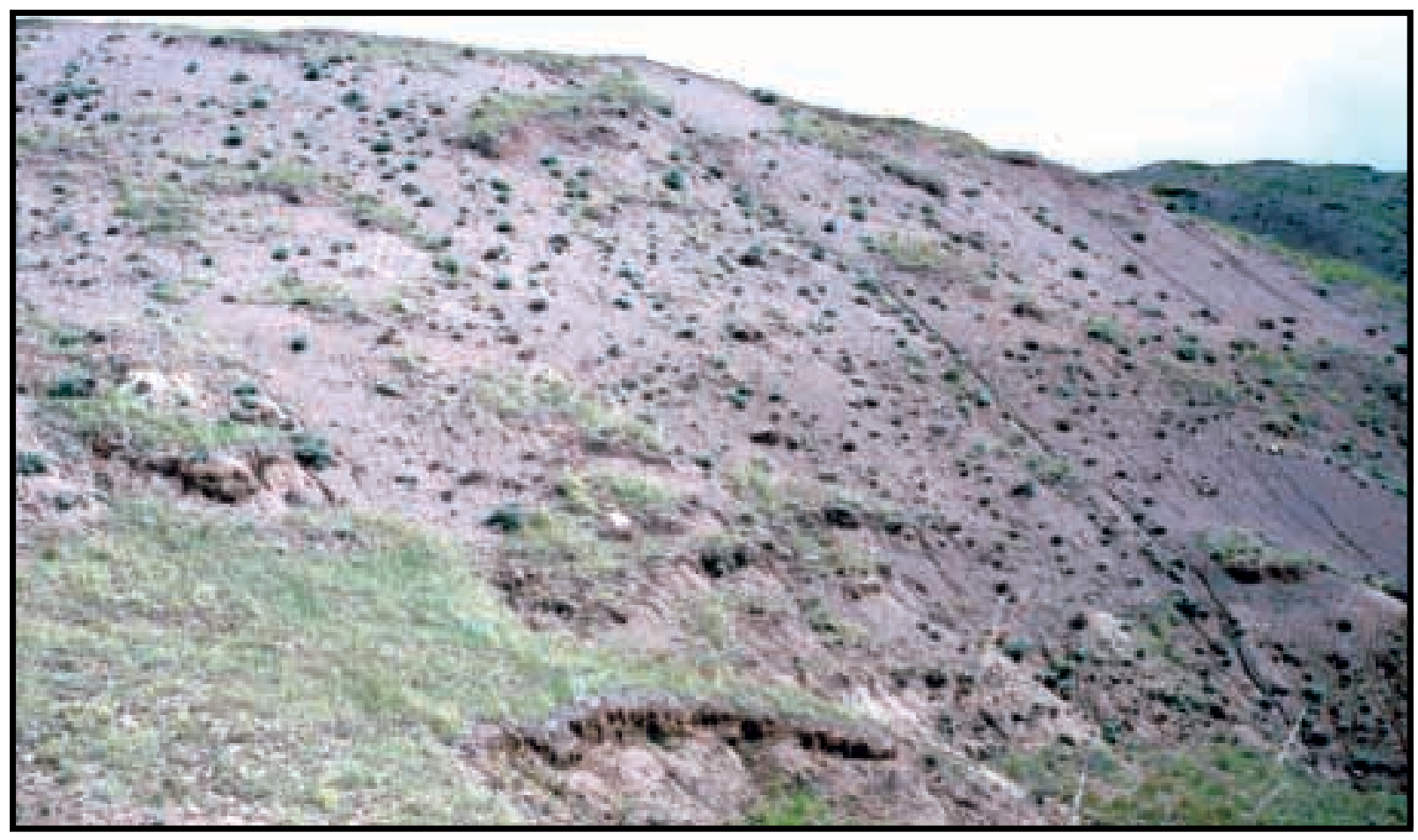

Longleaf sagewort Sparse Vegetation

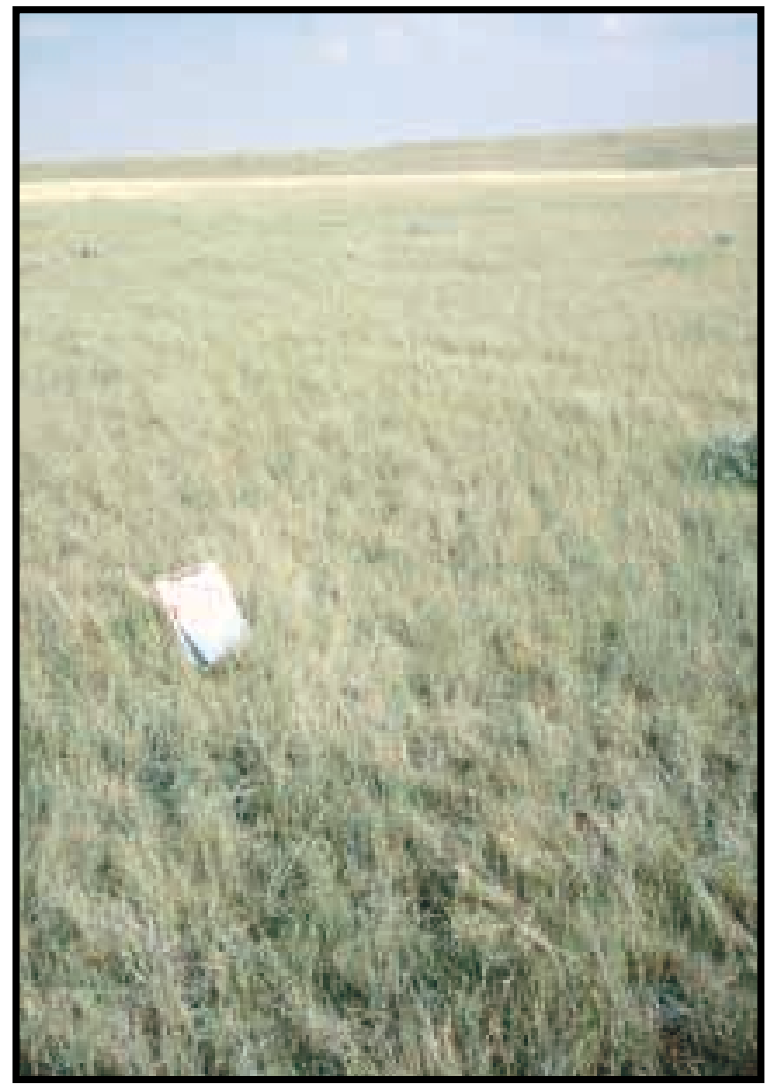

Western wheatgrass - (Needleleaf sedge) Herbaceous Vegetation 